\title{
Avaliação e critérios de eficiência nos processos de tratamento de fluido de corte por Eletroflotação
}

\author{
Fabiane Capraro Fogo
}

Dissertação apresentada ao Instituto de Química de São Carlos, da Universidade de São Paulo para obtenção do título de Mestre em Ciências (Química Analítica)

Orientadora: Profa Dra Maria Olímpia de Oliveira Rezende

São Carlos

2008 
Este exemplar foi revisado e alterado em relação à versão original, sob a exclusiva responsabilidade do autor.

São Carlos, 22/11/2008

Fabiane Capraro Fogo 


\section{Dedico}

Ao meu pai, pela educação dada, que me proporcionou a continuidade nos estudos até a chegada a este mestrado. 


\section{Agradecimentos}

À professora Dra. Maria Olímpia, por ter me aceitado ao grupo de Química Ambiental e pela orientação.

Ao CNPq pela bolsa concedida.

Aos amigos do LQA... Raquel, Paulo, Jussara, Elke, Joel, Mauricio, Flavia, Thomas, Paula, pelas conversas e apoio no meu trabalho.

A Divininha pelo apoio no laboratório e amizade.

Ao Elias... obrigada pela parceria nas pesquisas com fluido de corte e amizade.

Ao NUMA por ter cedido fluido de corte que foi objeto de estudo neste trabalho

Ao Paulo e Carlinhos (CAQI) pela ajuda com o ICP-AES

À Sílvia e a Andréa (secretárias da pós - graduação) pela dedicação e carinho em me receber.

Aos guardinhas pelo apoio e dedicação nos momentos complicados.

Ao Emerson, pela amizade e apoio no término do mestrado...e suas sábias palavras...

À Maristela pelo carinho e amizade concedida.

Agradeço aos amigos conquistados em São Carlos.... Fernanda, Flavinho, Joelma e Gustavo pelas conversas e trabalhos realizados juntos ...jamais esquecerei!!!

À Cátia e Amanda (desde a graduação juntas) pela amizade e incentivo em fazer pós-graduação.

Às meninas da REPÚBLICA da Dona Wirley..... Fayene, Vanessa e Daniela pelas alegrias e paz no doce lar ...que não era fácil...

Aos amigos da USP.... Renato (Chuck), Joemir, João, Hilário, Sandra, Eliane, Victor, Gustavo, Carlinhos e a Fay que sempre acompanharam minhas loucurassss !!!!! 


\section{SUMÁRIO:}

Sumário $\quad$ i

Índice de Figuras................................................................................................ iv

Índice de Tabelas............................................................................................... vi

Resumo............................................................................................................... vii

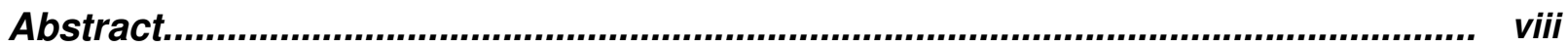

Símbolos e Abreviações.................................................................................... vii

1. INTRODUÇÃO.................................................................................................. 1

1.1 Processo de usinagem............................................................................... 2

1.1.2 Fluidos de corte: classificação e propriedades....................................... 3

1.1.3. Gerenciamento de resíduos de fluido de corte e a Legislação......................... 6

1.1.3.1 Gerenciamento de fluido de corte integral........................................... 9

1.1.3.2 Gerenciamento de fluidos de corte à base de água.............................. 9

1.2 Técnicas de Tratamento de Resíduos Líquidos........................................ 12

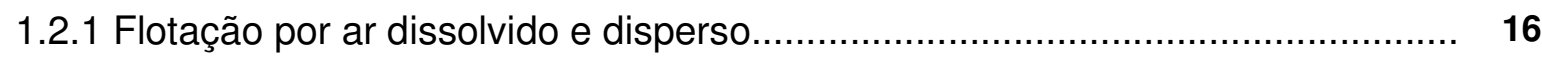

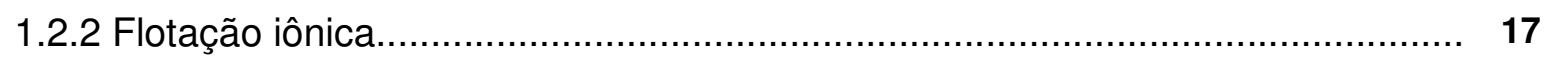

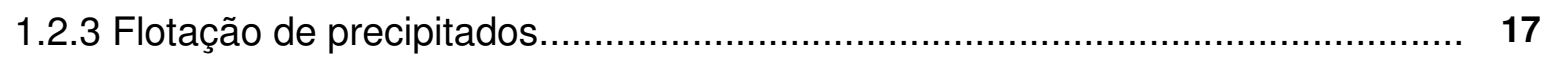

1.2.4 Flotação de colóides........................................................................... 18

1.3 Eletroflotação........................................................................................... 18

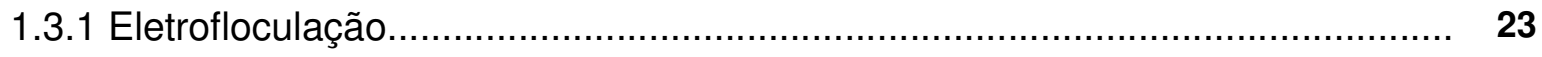

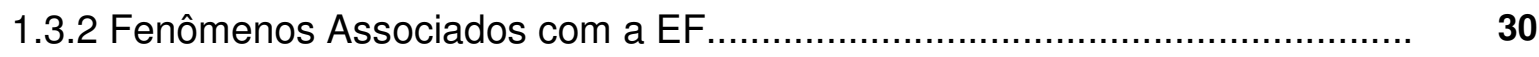

1.3.3 Trabalhos envolvendo a Eletroflotação............................................ $\quad 37$

2.OBJETIVOS............................................................................................... 37

3. PARÂMETROS ESTUDADOS: FUNDAMENTOS E METODOLOGIAS................... 39

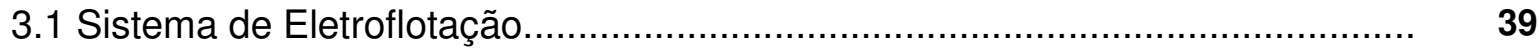


3.2 Parâmetros utilizados no tratamento com EF.....

3.3 Métodos de Caracterização............................................................................... 41

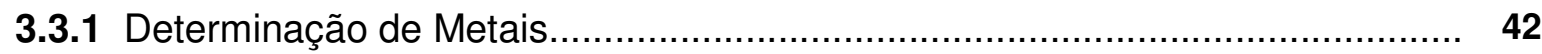

3.3. 2 Verificação da adsorção de metais nos eletrodos de alumínio..................... 45

3.3.3 Determinação de sólidos totais, óleos e graxas e carbono orgânico total.

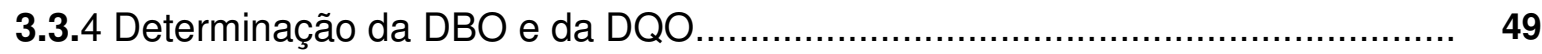

3.3.5 Determinação da Condutividade......................................................... 52

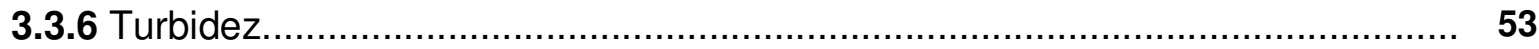

3.3.7 Nitrogênio Kjeldahl Total e Nitritos.................................................... 55

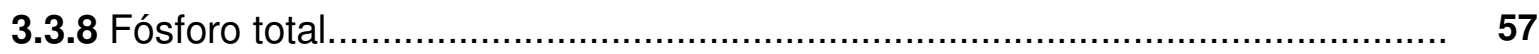

3.3.9 Métodos Cromatográficos (BTEX, HPAs e Nitrosaminas) .......................... 58

4.RESULTADOS E DISCUSSÃO........................................................................... 65

4.1 Caracterização do resíduo após o processo de usinagem........................... 65

4.2 Tratamento do fluido de corte utilizando a EF ....................................... 67

4.2.1 Parâmetros da EF ....................................................................... $\quad 70$

4.3 Determinação de metais......................................................................... 72

4.3.1 Adsorção de metais nos eletrodos de Alumínio...................................... 77

4.4 Determinação de Carbono Orgânico Total (COT) ........................................ 78

4.4.1 Determinação de sólidos totais, carbono orgânico total e óleos e $\mathbf{7 9}$ graxas.

4.4.2 Determinação da DBO e DQO........................................................... 81

4.5 Determinação da Turbidez e Condutividade............................................ 83

4.7 Determinação de nitrogênio e nitrito..................................................... 84

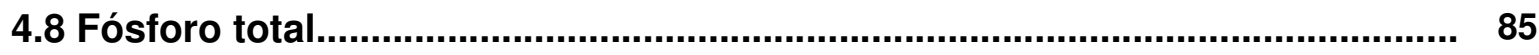

4.9 Análises Cromatográficas.................................................................... 86 
4.9.1 Disposição Final do Lodo........................................................................... 92

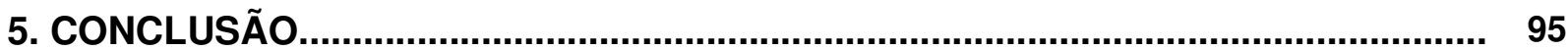

$\begin{array}{ll}\text { 6. Trabalhos Futuros } & 95\end{array}$

7. REFERÊNCIAS BIBLIOGRÁFICAS................................................................. 97 


\section{ÍNDICE DE FIGURAS}

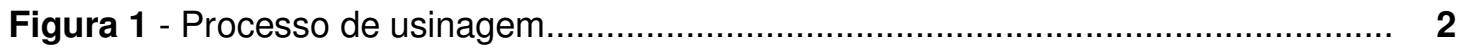

Figura 2 - Solubilidade do alumínio em função do pH (extraído de MOLLAH et al., 2001).

Figura 3 - Estruturas dímeras (à esquerda) e poliméricas (à direita)(extraído de MOLLAH et al., 2001).

Figura 4 - Curva de energia de repulsão e de atração em função da distância entre duas partículas coloidais semelhantes em solução de baixa concentração iônica (extraído de CRESPILHO; E REZENDE, 2004).....

Figura 5 - Configuração esquemática da dupla camada elétrica (extraído de CRESPILHO ; REZENDE, 2004)

Figura 6 - Reator eletrolítico de bancada promovendo a separação por flotação (extraído de CASQUEIRA; E TOREM, 2002).

Figura 7 - Fotografia do reator eletroquímico.

Figura 8 - Fotografia do sistema eletroquímico.

Figura 9 - Experimento realizado mostrando o decaimento do potencial em função do tempo de tratamento com a EF.

Figura 10 - Determinação de sólidos totais em diversas correntes aplicadas

Figura 11 - Imagens fotográficas dos resíduos; A ) fluido de corte não tratado (BRUTO); B) fluido de corte tratado com $0,75 \mathrm{~A} ; \mathrm{C}$ ) fluido de corte tratado com $1,00 \mathrm{~A} \ldots . .$.

Figura 12 - Imagem fotográfica durante o processo de tratamento do fluido de corte por EF com $0,75 A$.

Figura 13 - Curvas Analíticas para determinação de metais por ICP- AES.

Figura14 - Concentração de metais Bruto: fluido de corte após o processo de usinagem; Tratado: fluido de corte após o tratamento com a EF; VMP : valores permitidos pelo Decreto no 8.468, de setembro de 1976; Lodo : parte removida dos poluentes durante a EF

Figura15 - Concentração de metais Bruto: fluido de corte após o processo de usinagem; Tratado: fluido de corte após o tratamento com a EF; VMP : valores permitidos pelo Decreto no 8.468, de setembro de 1976; Lodo : parte removida dos poluentes durante a EF

Figura 16 - Concentração dos metais adsorvidos nas placas de alumínio após vários tratamentos do fluido de corte com a EF.

Figura17 - Curva analítica para determinação de COT 
Figura 18 - Relação entre a determinação de COT sem a inversão da polaridade em função do tempo de tratamento com uma corrente de $0,75 \mathrm{~A}$.

Figura19 - Eficiência da remoção de sólidos totais dissolvidos, carbono orgânico total e óleos e graxas. Bruto: resíduo após a usinagem; Tratado: resíduo após o processo de EF com uma corrente de 0,75A.

Figura 20 - Determinação de DBO e DQO; Bruto resíduo após a usinagem; Tratado: resíduo após o processo de EF com uma corrente de 0,75A.

Figura 21 - Determinação de nitrogênio Kjeldahl e nitrito; Bruto : resíduo após a usinagem; Tratado: resíduo após o processo de EF com uma corrente de 0,75A Lodo: parte removida

dos contaminantes

Figura 22 - Concentração de fosfatos; Bruto: resíduo após a usinagem; Tratado: resíduo após o processo de EF com uma corrente de 0,75A; Lodo : parte removida dos contaminantes.

Figura 23 - Análise de BTEX e HPAs antes e após o processo de usinagem: 1 e 2 fluido de corte antes do processo de usinagem - BTEX e HPAs respectivamente; 3 e 4 fluido de corte após o processo de usinagem - BTEX e HPAs respectivamente.

Figura 24 - Análise de HPAs para os experimentos utilizando Eletroflotação após 20 min (Experimento 01 e 03) e após 10 min(Experimento 02).

Figura 25 - Análise de BTEX para os experimentos utilizando Eletroflotação após 20 min (Experimento04 e 06) e após 10 min (Experimento 05)

Figura 26 - Cromatograma de amostras de fluido de corte antes (1) e após (2) o processo de usinagem, os espectros de massa estão abaixo de cada cromatograma e representam os cinco primeiros picos do espectro.

Figura 27 - Análise de BTEX para os experimentos utilizando Eletroflotação após 20 min: Tratado (Experimento07) e o lodo (Experimento 08). 


\section{ÍNDICE DE TABELAS}

Tabela1 - Cronologia dos trabalhos envolvendo EF.

Tabela 2 - Concentrações limites de metais para lançamentos de efluentes (Decreto no 8.468 de 08/09/1976 da Legislação Estadual SP).

Tabela 3 - Condições espectrométrica para determinação de metais.

Tabela 4 - Tempo de retenção obtido para uma mistura de BTEX padrão, utilizando-se um cromatógrafo a gás com detector de ionização de chama.

Tabela 5 - Tempo de retenção obtido para uma mistura de HPAs padrão, utilizando-se um cromatógrafo a gás com detector de ionização de chama.

Tabela 6 - Parâmetros de qualidade do fluido de corte e os valores permitidos para descarte.

Tabela 7 - Parâmetros do resíduo tratado por EF................................................... 67

Tabela 8 - Parâmetros de tratamento sem inversão da polaridade.............................. 71

Tabela 9 - Parâmetros calculados após o tratamento com a Eletroflotação para uma corrente de $0,75 \mathrm{~A}$

Tabela 10 - Determinação de metais no efluente estudado......................................... 74

Tabela 11 - Eficiência da EF na remoção de poluentes........................................... 80

Tabela 12 - Eficiência da EF na redução da DBO e DQO .......................................... 82

Tabela 13 - Eficiência da EF nos valores de turbidez e condutividade.......................... 83

Tabela 14 - Concentrações de BTEX no resíduo de fluido de corte............................... 88

Tabela 15 - Concentração de HPAs no resíduo de fluido de corte............................... 88

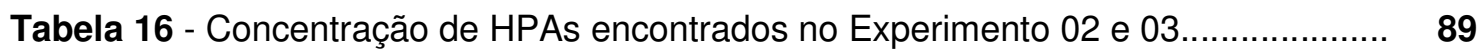

Tabela 17 - Concentração de BTEX encontrados no Experimento 05 e $06 \ldots \ldots \ldots \ldots \ldots \ldots \ldots . . . . . .90$ 


\section{RESUMO}

No processo de usinagem são utilizados fluidos de corte para facilitar a fabricação de peças metálicas, que tem resultado em problemas de várias ordens, que vão desde a geração de efeitos nocivos no ambiente de trabalho até a agressão do meio ambiente com seu descarte inadequado. Os fluidos de corte são compostos por óleos graxos e minerais, soluções sintéticas e água, substâncias carcinogênicas devido à formação de nitrosaminas, além de aditivos à base de cloro, nitrito, fósforo e aminas. Muitos dos processos utilizados em estações de tratamento de efluentes envolvem a adição de agentes coagulantes e floculantes, como, polímeros e sais de sulfato de ferro e alumínio. Estas substâncias mesmo em baixas concentrações provocam impactos ambientais, alterando o equilíbrio do corpo receptor. No presente projeto de pesquisa foi desenvolvido o tratamento do fluido de corte sintético utilizando a Eletroflotação, uma técnica eletroquímica, que utiliza eletrodos de sacrifício de alumínio para geração in situ de um agente coagulante. Simultaneamente, micro bolhas de gases são geradas como resultado da eletrólise da água devido à aplicação de uma diferença de potencial entre os eletrodos. Após a coagulação, os colóides podem ser flotados e removidos. Para verificar a eficiência do processo foi realizada a caracterização do fluido de corte antes e após o tratamento comparando alguns valores com os resultados pertinentes na Legislação Estadual de São Paulo, o Decreto no 8.468 de 8 de setembro de 1976. As caracterizações foram: determinação de $\mathrm{pH}$ e turbidez, metais, fósforo total, nitrogênio, nitrito, demanda química de oxigênio, demanda bioquímica de oxigênio, oxigênio dissolvido, sólidos totais, carbono total, concentração de óleos e graxas, condutividade, hidrocarbonetos policíclicos aromáticos (HPAs), benzeno, tolueno e xilenos (BTEX) e nitrosaminas. Os resultados obtidos demonstraram que a inversão da polaridade não resultou uma melhor eficiência no tratamento de fluido de corte com a EF. A redução de metais foi satisfatória de acordo com a legislação. Os sólidos totais, nitritos e fosfatos presentes foram parcialmente removidos constatando a eficácia da EF na redução de compostos inorgânicos. A diminuição de concentração de óleos e graxas, carbono orgânico total, demanda química e bioquímica de oxigênio mostrou a eficiência na remoção de compostos orgânicos presentes no resíduo. O tratamento com a EF resultou na remoção total de BTEX e HPAs. As nitrosaminas não foram constatadas no resíduo. Os poluentes durante a EF foram dispostos para o lodo, diminuindo o volume a ser posteriormente destruído.

Palavras chaves: fluido de corte, eletroflotação, tratamento de resíduos 


\begin{abstract}
In the machining process cutting fluids are used to facilitate the manufacture of metal parts, which has resulted in problems of various orders, ranging from the generation of harmful effects on the desktop to the aggression of the environment with their improper disposal. The cutting fluids are composed of oils and minerals, synthetic solutions and water, carcinogenic substances due to the formation of nitrosamines, as well as chlorine-based additives, nitrite, phosphorus and amines. Many of the processes used in sewage treatment stations involve the addition of coagulants and flocculants agents, such as polymers and iron and aluminum salts. These substances even at low concentrations cause environmental impacts, altering the balance of the receiver body. In this research project it was developed a method to treat synthetic cutting fluid using the Eletroflotation, an electrochemical technique, which uses aluminum sacrifice electrodes to generate in situ a coagulating agent. Simultaneously, micro-gas bubbles are generated as a result of the water electrolysis due to the application of a potential difference between the electrodes. After coagulation, the colloids can be float and removed. To check the efficiency of the procedure it was performed a characterization of the cutting fluid before and after treatment comparing some values with the results relevant legislation in the State of São Paulo, the Decree n-. 8468 of September 8th, 1976. The characterizations were: determination of $\mathrm{pH}$ and turbidity, metals, total phosphorus, total nitrogen, nitrite, chemical oxygen demand, biochemical oxygen demand, dissolved oxygen, total solids, total carbon, concentration of oils and greases, conductivity, polycyclic aromatic hydrocarbons (PAHs), benzene, toluene and xylenes (BTEX) and nitrosamines. The results showed that the polarity reversion did not result in more efficient processing of cutting fluid with the EF. The metals reduction has been satisfactory under the law. The total solids, nitrates and phosphates present were partially removed noting the effectiveness of EF in the reduction of inorganic compounds. The decrease of oils and greases concentration, total organic carbon, demand chemical and biochemical oxygen showed the efficient removal of organic compounds present in the residue. The treatment with Eletroflotation resulted in total removal of BTEX and PAHs. The nitrosamines were not found in the residue. The pollutants during the Eletroflotation were transferred to the mud, reducing the volume to be subsequently destroyed.
\end{abstract}

Key words: fluid cutting, eletroflotation, residue treatment. 


\section{Símbolos e Abreviações}

ASTM - Sociedade Americana para testes e materiais

BTEX - benzeno, tolueno, etilbenzeno e xilenos

CETESB - Companhia de Tecnologia de Saneamento Ambiental

CONAMA - Conselho Nacional do Meio Ambiente

DBO - Demanda Bioquímica de Oxigênio

DQO - Demanda Química de Oxigênio

EF - Eletroflotação

FAD - Flotação por ar dissolvido

FID - Detector de ionização de chama

HPAs - Hidrocarbonetos policíclicos aromáticos

ICP-AES - Plasma indutivamente acoplado-espectrometria de emissão atômica

LOD - Limite de Detecção

LOQ - Limite de Quantificação

OSHA - Agência Européia para a Segurança e Saúde

USEPA - Agência de Proteção Ambiental dos Estados Unidos 
INTRODUÇÃO 


\section{INTRODUÇÃO}

\subsection{Processo de Usinagem}

Como parte integrante dos processos de manufatura industrial encontram-se os processos de usinagem, que, basicamente, constituem em dar forma a peças e acessórios através da remoção de material. Na grande maioria dos processos de usinagem é necessário o emprego de um agente, fluido de corte, que desempenha diversas funções com o propósito de se obter benefícios tecnológicos no processo (DRODZDA;E WICK,1983).

Um fluido de corte é um material composto, na maioria das vezes, líquido, que deve ser capaz de: refrigerar, lubrificar, proteger contra a oxidação e limpar a região da usinagem. A Figura 1 mostra a aplicação do fluido de corte em uma peça metálica sendo usinada. Como refrigerante atua sobre a ferramenta e evita que ela atinja temperaturas muito altas e perca suas características de corte. Age, também, sobre a peça, evitando deformações causadas pelo calor. Atua, finalmente, sobre o cavaco, reduzindo a força necessária para que seja cortado.

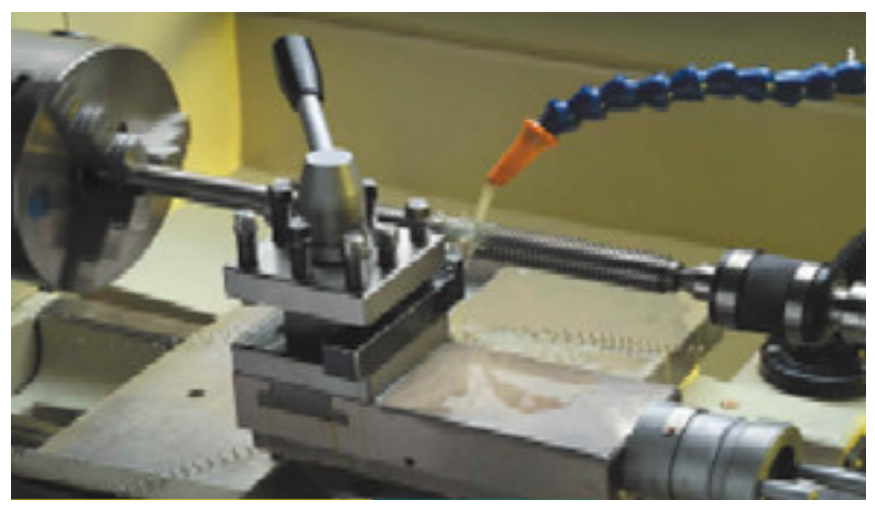

Figura 1: Processo de usinagem 
Como lubrificante, o fluido de corte facilita o deslizamento dos cavacos sobre a ferramenta e diminui o atrito entre a peça e a ferramenta. Evita ainda o aparecimento de aresta postiça, reduz o coeficiente de atrito na região de contato ferramenta-cavaco melhorando o rendimento da máquina.

Como protetor contra oxidação, ele protege a peça, a ferramenta e o cavaco, contribuindo para o bom acabamento e aspecto final do trabalho.

A ação de limpeza ocorre como conseqüência da aplicação do fluido de corte em forma de jato, cuja pressão afasta as aparas deixando limpa a zona de corte e facilitando o controle visual da qualidade do trabalho.

O uso de agentes de corte gasosos visa principalmente à refrigeração, embora o fato de estar sob pressão auxilie também a remoção de cavacos. Para essas finalidades, usa-se $\mathrm{o}$ ar comprimido em temperaturas abaixo de $0^{\circ} \mathrm{C}, \circ \mathrm{CO}_{2}$ (dióxido de carbono ou gelo-seco) para altas velocidades de corte de ligas de difícil usinagem e o nitrogênio para operações de torneamento.

Os sólidos visam somente à lubrificação no processo de usinagem. É o caso do grafite e do bissulfeto de molibdênio, aplicados na superfície de saída da ferramenta antes que se inicie o processo de corte (IGNÁCIO,1998).

\subsubsection{Fluidos de corte: classificação e propriedades}

Entre os primeiros pesquisadores expressivos a estudarem os fluidos de corte no processo de usinagem encontramos W. H. Northcott e F. W. Taylor, os quais, num primeiro momento, utilizaram a água na região de corte. Naturalmente a idéia da água surgiu com o intuito de minorar o indesejável efeito da alta temperatura, mas trouxe consigo desvantagens como a oxidação do conjunto máquinaferramenta-peça, além da ausência do poder de lubrificação. Todavia, ao serem 
constatadas estas desvantagens e a necessidade de descobrir novos fluidos de corte, as pesquisas nos trouxeram as mais variadas combinações desse produto.

A escolha do fluido com determinada composição depende do material a ser usinado, do tipo de operação de corte e da ferramenta usada. Os fluidos de corte solúveis e os sintéticos são indicados quando a função principal é refrigerar. Os óleos minerais, graxos usados juntos ou separados, puros ou contendo aditivos especiais são usados quando a lubrificação é mais importante que o resfriamento.

Através de nossos estudos, percebemos que existe um conflito em torno da classificação dos fluidos de corte. A mais conhecida é citada por Motta e Baradie, que apresentam a classificação desse produto dividida basicamente em duas classes: integrais e solúveis (BARADIE, 1996; MOTTA; MACHADO1995).

A seguir encontra-se a classificação de fluidos existentes, porém, este trabalho foi realizado com fluido do tipo sintético.

Os fluidos de corte integrais são formados por óleos minerais, e até mesmo por óleos animais e vegetais em sua composição. Os solúveis são subdivididos em emulsões e soluções e são formados pela adição de óleos minerais, com propriedade de serem solúveis em água, numa solução que apresenta a adição de aditivos com propriedades antissolda, anticorrosão, antioxidação e extrema-pressão, entre outros.

$\mathrm{Na}$ subclasse das emulsões, encontram-se as emulsões propriamente ditas que, além dos compostos descritos acima, possuem acrescentados em suas fórmulas os compostos bactericida e biocida. Encontram-se, também, os fluidos semi-sintéticos, aos quais, além de água, são acrescentados os emulsificadores e agentes umectantes. 
Segundo Baradie, o fluido sintético é formado por sais orgânicos e inorgânicos dissolvidos em água, não contendo óleo mineral. Possuem ótimo poder de refrigeração, excelente poder detergente, levam à melhora da visibilidade na região de corte e elevada resistência à oxidação do fluido. As desvantagens são o baixo poder lubrificante e a formação de compostos insolúveis e de espumas para determinadas operações (BARADIE, 1996; MOTTA; MACHADO1995).

Os fluidos de corte exigem algumas providências e cuidados de manuseio que garantem seu melhor desempenho nas operações de usinagem: armazenamento, alimentação, recuperação e controle de odor.

Embora os processos de produção dos fluidos de corte estejam cada vez mais aperfeiçoados para eliminar componentes indesejáveis, não só no que se refere ao uso, mas também aos aspectos relacionados à saúde do usuário, o contato prolongado com esses produtos pode trazer uma série de problemas de pele, genericamente chamados de dermatite (RUNGE, 1990).

Os fluidos de corte são classificados como resíduos compostos por substâncias perigosas por apresentarem toxicidade devido à formação de ácidos orgânicos, compostos aromáticos polinucleares potencialmente carcinogênicos, resinas e lascas durante o processo de usinagem, já que o mesmo é realizado às altas temperaturas. As N-nitrosaminas são potentes carcinogênicos, teratogênicos e mutagênicos em animais de laboratório. Durante a usinagem, as N-nitrosaminas podem ser formadas, pela nitrosação de aminas secundárias, as quais podem estar associadas com um alto risco de câncer gástrico, hepático e de esôfago.

Considera-se que o descarte para o solo ou cursos de água de óleo lubrificante puro, assim como o emulsionável usado, gera graves danos ao meio 
ambiente, e que a combustão dos óleos lubrificantes usados pode gerar gases residuais nocivos à saúde humana.

A gravidade de contaminação com o óleo lubrificante usado é de caráter perigoso e as atividades de gerenciamento de óleos lubrificantes devem estar organizadas e controladas de modo a evitar danos à saúde pública e ao meio ambiente (IGNÁCIO, 2007).

\subsubsection{Gerenciamento de resíduos de fluido de corte e a Legislação}

A utilização de fluido de corte nos processos de usinagem tem sido altamente questionada, principalmente devido às pressões de uma legislação cada vez mais severa com os descartes industriais e a uma crescente conscientização quanto aos problemas ambientais.

As indústrias devem buscar constantemente garantir a qualidade de seus produtos e do meio ambiente investindo em processos ambientalmente corretos e no tratamento, reciclagem e reutilização de seus resíduos. As empresas podem tirar vantagens competitivas dessa questão através de uma constante investigação acerca do controle e redução dos resíduos gerados em seus processos produtivos.

No Brasil, onde a produção e utilização de máquinas-ferramentas é expressiva, o volume consumido de fluidos de corte certamente é significativo. Assim, o investimento em tecnologia para a melhor utilização e tratamento dos resíduos desse produto se faz necessário, o que pode reduzir os custos de produção e evitar multas para a empresa.

Com o término da vida útil, os fluidos de corte perdem suas propriedades e a recuperação ou o descarte destes é uma questão de planejamento. O integral pode ser vendido ou ser tratado dentro da própria empresa. As soluções e emulsões, que 
praticamente não têm valor comercial, devem ser tratadas por processo físicoquímico para a quebra e separação de seus componentes antes de serem reaproveitadas ou descartadas.

No momento do descarte de fluidos de corte usados, e seus resíduos, algumas empresas, muitas vezes por falta de informações técnicas e desconhecimento da legislação pertinente, apresentam as seguintes práticas incorretas na destinação final de fluidos de corte usados:

- $\quad$ manejo inadequado;

- $\quad$ ausência de um plano de tratamento;

- $\quad$ armazenagem inadequada;

- $\quad$ transporte impróprio;

- $\quad$ entrega a receptores não autorizados e

- $\quad$ disposição de resíduos em local não autorizado.

Os efluentes de qualquer fonte poluidora somente poderão ser lançados em sistema de esgotos provido de tratamento com capacidade e de tipo adequado, conforme previsto de acordo com a Legislação do estado de São Paulo, o Decreto no 8.468, de 8 de setembro de 1976 que retrata sobre a prevenção e o controle do meio ambiente.

O descarte do fluido de corte é um processo indesejável, tanto pelo seu alto custo como pelos procedimentos legais que o envolvem, uma vez que deve ser feito por empresas especializadas e requer análise e aprovação da CETESB que, por último indica o destino a ser dado (MONICl,1999).

No Brasil, o órgão responsável pela fiscalização das Leis Ambientais Brasileiras em relação à utilização e descarte de fluidos de corte é o CONAMA (Conselho Nacional do Meio Ambiente). Sendo que a Resolução no 9, de 31 de 
Agosto de 1993, considera crime ambiental não só descartar óleo lubrificante na natureza, mas também comercializar, fornecer, transportar, queimar ou dar outro destino que não a reciclagem através do rerrefino. Nos casos onde não seja possível a reciclagem, o órgão ambiental competente poderá autorizar a sua combustão para aproveitamento energético ou incineração desde que seja atendido os padrões de emissões de gases para a atmosfera (CONAMA,1993).

A Resolução CONAMA nํ 313, de 29 de outubro de 2002, dispõe sobre o Inventário Nacional de Resíduos Sólidos Industriais, ou seja, as indústrias devem apresentar aos órgãos ambientais estaduais informações sobre geração, composição, armazenamento, transporte e destinação final de resíduos sólidos.

Segundo a norma NBR 10004 resíduo sólido industrial é todo o resíduo que resulte de atividades industriais e que se encontre nos estados sólido, semi-sólido, gasoso e líquido, cujas particularidades tornem inviável o seu lançamento na rede pública de esgoto ou em corpos d`água, ou exijam para isso soluções técnica ou economicamente inviáveis em face da melhor tecnologia disponível. Ficam incluídos nesta definição os lodos provenientes de sistemas de tratamento de água e aqueles gerados em equipamentos e instalações de controle de poluição.

Os óleos lubrificantes oferecem riscos ao meio ambiente e à saúde por estarem classificados como perigosos. Apesar disso, muitas vezes são descartados diretamente na natureza, seja pela ausência de sistemas de tratamento e ou gerenciamento inadequado (CONAMA, 2002).

Os efluentes de qualquer fonte poluidora somente poderão ser lançados, direta ou indiretamente, nos corpos de água, após o devido tratamento e desde que obedeçam às condições, padrões e exigências dispostos na Resolução №357, 17 de março de 2005, e em outras normas aplicáveis (CONAMA, 2005). 


\subsubsection{Gerenciamento de fluido de corte integral}

Os fluidos de corte integrais, quando mantidos livres de contaminantes, podem ser usados indefinidamente. Porém, o acúmulo de contaminação provoca a deterioração dos aditivos e das propriedades dos fluidos integrais, contribuindo para abreviar a vida útil do fluido de corte. Embora inadequados à utilização para a qual foram originalmente fabricados, eles podem ser aproveitados em operações de lubrificação de menor exigência (QUEIROZ, 2001).

Os fluidos de corte integrais podem ser recuperados pelo próprio usuário, pelo fabricante do fluido ou por uma companhia especializada.

Em geral, nas reciclagens dos fluidos integrais retiram-se os contaminantes e substitui-se algum aditivo que foi degradado e o fluido recuperado pode então voltar a ser utilizado.

Quando for inviável a reciclagem ou a reutilização, o fluido pode ainda servir de combustível, desde que o forno e o fluído atendam às exigências da legislação específica para a queima de compostos de hidrocarbonetos que, entre outras exigências, não devem conter na sua constituição nenhum composto com cloro (QUEIROZ, 2001).

\subsubsection{Gerenciamento de fluidos de corte a base de água}

Os fluidos sintéticos ou soluções são constituídos de uma grande gama de produtos químicos. A maioria destes fluidos caracteriza-se pelas seguintes propriedades: alcalinidade $(\mathrm{pH}$ entre 7,8 e 10,2); elevadas cargas orgânicas, constituídas de cadeias retas e de fácil degradação por bactérias inoculadas e por oxidação química. 
Muitos produtos químicos usados na composição dos fluidos de corte, como biocidas, anticorrosivos, umectantes, flavorizantes, antiespumantes e outros aditivos, podem ter efeitos nocivos sobre o homem e a natureza. Com a evolução tecnológica, uma grande quantidade de novos produtos sintéticos são lançados no mercado para os quais não existem testes toxicológicos adequados e, como é complexa a tarefa de monitorá-los, os órgãos ambientais americanos recomendam atitudes preventivas ( RUNGE, 1990).

A OSHA (Occupation Safety and Health Administration) regulamentou algumas substâncias a serem observadas nas formulações de fluidos de corte, entre elas estão:

-etanolamina;

- dietanolamina;

- hexileno glicol;

- morfolina;

- p-cloro-m-cresol;

- policlorados alcalinos de $\mathrm{C}_{10}$ a $\mathrm{C}_{13}$;

-3-iodo-2pronilbutil carbamato;

- nitrodietanolamina;

$\bullet$ o-fenilfenol

•éter de glicol

- solvente de Stoddard;

$\bullet$ nitritos;

-óleos de cadeias polinucleares aromáticas (PNA);

-óleo parafínicos clorados de cadeias curtas;

- compostos de bário; 
• névoa de óleo e

- compostos de cobre.

Um fluido que contenha qualquer um destes compostos não pode ser considerado "limpo", apesar de que nenhum efeito específico possa ser comprovadamente ligado ao uso de tais substâncias. Entretanto, alguns efeitos nocivos foram associados a tais componentes, assim, o recomendável é a precaução (RUNGE, 1990).

As emulsões e soluções não podem ser simplesmente descartadas no sistema de esgoto, havendo a necessidade de separar o óleo da água (no caso de emulsões) com posterior tratamento da fase aquosa.

A hidrólise ácida (Método Químico) consiste na adição de ácidos para abaixar o $\mathrm{pH}$ e de sais metálicos (sulfato de alumínio, cloreto férrico ou sulfato ferroso) para formar sabões insolúveis, levando à quebra da emulsão. A fase aquosa resultante da separação do óleo contém metais provenientes da manufatura da peça, desta forma deve-se precipitá-los. Após sua neutralização, a água deve estar de acordo com a legislação vigente para seu descarte. A fase oleosa separada é removida, sendo tratada como fluido integral. O resíduo sólido produzido na neutralização deve ser analisado e descartado conforme a legislação vigente local (RUNGE,1990)

A quebra química de emulsões somente é bem sucedida quando os compostos são íons-ativos. Os resíduos do óleo poderão ser retirados por meios mecânicos ou absorvidos por hidróxidos metálicos ou sílica (QUEIROZ, 2001).

A quebra da emulsão pode ser feita pelo aquecimento da mistura (Método Térmico) onde a água evapora, separando-se do óleo. A vantagem deste processo é a de não se utilizar de outros compostos químicos para realizar a quebra da emulsão. Esse detalhe facilita o tratamento final dos resíduos; porém é necessário 
um grande dispêndio de energia para provocar a evaporação da água (QUEIROZ 2001).

Os métodos biológicos ainda são pouco utilizados como alternativa de tratamento de fluidos de corte, pois sua principal limitação é a quantidade de biocidas encontrados nesses fluidos. O princípio básico do seu funcionamento é o desenvolvimento de microorganismos que eliminem os resíduos indesejáveis. No entanto, a carga de biocidas existente é que impede o desenvolvimento de tratamentos à base de microorganismos (QUEIROZ 2001).

Observando a complexidade para do gerenciamento dos resíduos de fluidos de corte, conclui-se que é necessária uma metodologia eficiente para se realizar uma manipulação responsável dos fluidos de corte a fim de reduzir seus resíduos e garantir um ambiente seguro e sem riscos à saúde humana. A gestão dos problemas ambientais provocados pelo uso dos fluidos de corte irá gerar custos, mas seu resultado irá melhorar o controle e a manutenção dos fluidos, possibilitando uma melhor qualidade ambiental (QUEIROZ 2001).

Dentro desse contexto, este trabalho teve como motivação apresentar um tratamento ambientalmente correto para o descarte de fluido de corte sintético.

\subsection{Técnicas de Tratamento de Resíduos Líquidos}

De uma forma geral, os processos disponíveis para utilização no tratamento de resíduos líquidos são: processos físicos, processos físico-químicos e processos biológicos.

Os processos físicos estão sempre associados aos tratamentos preliminares e primários, promovem a remoção de sólidos flutuantes (ou não) geralmente de dimensões relativamente grandes, de sólidos em suspensão, areias, óleos e 
gorduras. Para essa finalidade são utilizados principalmente grades, peneiras, caixas de areia, tanques próprios para a remoção de óleos e graxas, flotadores, decantadores e filtros.

Os processos físico-químicos podem ser subdivididos em dois tipos: os processos tradicionais que atuam pela ação de produtos químicos coagulantes; e processos eletrolíticos que utilizam a eletrólise para a geração do agente coagulante (GANI, 2002).

Os processos físico-químicos tradicionais consistem em transformar em flocos, ou compostos insolúveis, as impurezas em estado coloidal, suspensões, metais pesados, corantes, óleos, compostos tóxicos e etc. As reações que provocam a precipitação química ocorrem por adição de produtos químicos coagulantes (normalmente, sulfato de alumínio ou cloreto férrico), e/ou pela variação no $\mathrm{pH}$ do resíduo líquido.

A tecnologia eletrolítica de tratamento de efluentes aplica o mesmo princípio físico-químico do processo tradicional, pela promoção de reações de coagulaçãofloculação, que transformam impurezas em flocos "sólidos", formando genericamente duas fases distintas: efluente líquido tratado e resíduo sólido (lama de tratamento), separados normalmente por sedimentação, flotação e/ou filtração.

As partículas em suspensão coloidal que conferem turbidez às águas. A estabilidade dessas partículas dispersas se deve a forças eletrostáticas de repulsão entre os colóides de mesma carga, formando uma barreira de energia (potencial zeta). Os coagulantes químicos, como sais de alumínio e de ferro, reagem com a alcalinidade contida ou adicionada nos resíduos líquidos, formando hidróxidos que desestabilizam os colóides, as partículas em suspensão, etc., pela redução do seu potencial zeta a valores próximos a zero, denominados ponto isoelétrico. 
Teoria semelhante ao tratamento físico-químico tradicional é aplicada ao processo eletrolítico. Nesse caso, os sais de alumínio e ferro estão representados pelos eletrodos (alumínio ou ferro), que atuam como fontes desses metais que irão formar hidróxidos insolúveis, promovendo a desestabilização dos colóides existentes no efluente líquido (OLIVEIRA; BRETT,1996).

Os processos biológicos dividem-se em aeróbios, anaeróbios e facultativos. O tratamento biológico procura reproduzir os mecanismos naturais de depuração da matéria orgânica biodegradável. É um processo de tratamento contínuo, geralmente ocupa grandes áreas, sendo mais utilizado para tratamento de efluentes sanitários. Quando empregado no tratamento de resíduos industriais atua como um complemento ao tratamento físico-químico.

Além dos métodos físicos, físico-químicos e biológicos existem ainda processos adsortivos por troca iônica e por oxidação química. Novas tecnologias também vêm sendo muito estudadas, entre elas os processos oxidativos avançados e as unidades de osmose reversa (BERNARDO,1993; IAGREGA; PHILIP; JEFFREEY, 2001)

Muitos processos utilizados em estações de tratamento de efluentes envolvem a adição de agentes coagulantes, como, por exemplo, polímeros e sais de ferro e de alumínio (RICHTER; NETTO,1991;STUMM; MORGAN,1981).

Tratamentos com polímeros podem causar impactos ambientais devido à toxicidade de algumas substâncias usadas, podendo, mesmo em baixas concentrações, desequilibrar o meio ambiente em relação aos organismos aquáticos do corpo receptor (SWIFT, 1998).

Outras substâncias que podem causar impacto ambiental, alterando o equílibrio do corpo receptor, são as provenientes dos coagulantes usados no 
tratamento químico, em que normalmente ocorre uma alteração na concentração de ânions e, consequentemente, uma mudança na condutividade do efluente, quando comparada com a qualidade da água de entrada na indústria. Os coagulantes à base de sulfatos elevam a concentração desse íon no efluente final, podendo alterar a qualidade da água do corpo receptor. Excesso de sulfato no leito poderá precipitar os íons cálcio presentes no sedimento e na água ou participar de processos de oxi-redução, gerando sulfetos em condições anaeróbicas (JONG; PARRY, 2003).

Os métodos baseados no princípio de coagulação são os mais utilizados, devido a sua ampla escala de atuação e, geralmente,menores custos operacionais. São aplicados para remoção de sólidos em suspensão e podem ser divididos em duas classes quanto ao tipo de lodo gerado: coagulação com sedimentação e coagulação com flotação (ECKENFELDER,1989; METCALF,1991).

A coagulação seguida de sedimentação consiste na remoção dos sólidos presentes no efluente por meio da separação das fases sólida e líquida, sendo a fase sólida (impurezas do efluente) sedimentada na parte inferior da estação de tratamento de efluente, enquanto a fase líquida (efluente tratado) é removida da estação pela parte superior, sendo descarregada no meio ambiente (ECKENFELDER, 1989; METCALF, 1991).

Na coagulação seguida de flotação ocorre uma inversão quanto à separação de fases, ou seja, as impurezas ( fase sólida flotada) são removidas da estação pela parte inferior. A seleção do método é realizada em função das características do efluente, temperatura e tamanho de partículas devem ser considerados (SANTANA, 2003). 
A flotação é um método de separação que abrange inúmeras aplicações no campo do beneficiamento mineral, e nos últimos anos tem sido de fundamental importância para o tratamento de efluentes e na reciclagem de materiais, como papel e plástico (OLIVEIRA; TOREM, 1995; BUCHAN; YARAR, 1995; CASQUEIRA et al., 2002).

\subsubsection{Flotação por ar dissolvido e disperso}

No processo de flotação por ar dissolvido ocorre a suspensão do material particulado e/ou coagulado. O resíduo é carregado por microbolhas, que são injetadas no fundo de um reator. Ao chegar à superfície do reator, a suspensão (resíduo flotado) pode ser removida por processos físicos convencionais, como raspagem e sucção, entre outros (SANTANA, 2003).

$\mathrm{Na}$ flotação por ar dissolvido, as bolhas são produzidas pela supersaturação do líquido, com o ar, podendo ser efetuada a vácuo ou a pressão.

Na flotação por ar disperso, a formação de bolhas de ar é feita por agitação do líquido, à pressão atmosférica, e os diâmetros das bolhas produzidas são relativamente grandes, cerca de $1.000 \mu \mathrm{m}$, quando comparados com o tamanho dos sólidos.

A flotação por ar dissolvido (FAD) permite maior flexibilidade ao processo, porque pode utilizar uma faixa de pressão maior, possibilitando um controle mais eficiente da quantidade de ar desprendido que, aliado ao pequeno tamanho das bolhas, constitui a principal vantagem no tratamento de efluentes (MAIA; BEZERRA, 1981). 


\subsubsection{Flotação iônica}

O processo de flotação iônica consiste nas diferenças das atividades superficiais das várias substâncias que podem estar presentes em solução ou em suspensão. As espécies a serem removidas são, geralmente, íons inativos superficialmente, chamados de coligantes. Estes são removidos das soluções aquosas por meio da adição de surfatantes (coletores e espumantes), que são capazes de formar complexos hodrofóbicos. Quando a fase gasosa é borbulhada na solução, o complexo coletor-coligantes formado adsorve na superfície do líquido através da espuma que é formada e é removido fisicamente da solução. Geralmente o surfactante utilizado possui um grupo funcional iônico com carga oposta ao coligante, cátions e ânions são flotados com coletores aniônicos e catiônicos respectivamente (PINFOLD, 1972; WALKOWIAK, 1992).

A eficiência da flotação iônica depende da escolha correta dos surfatantes (coletor e espumante) e do controle dos parâmetros químicos envolvidos no processo, tais como, pH e concentração iônica (GRIEVES,1990).

A utilização da flotação iônica como uma etapa de pré-concentração na análise de águas permite obter separações eficientes entre elementos químicos semelhantes. Recuperações quantitativas deste processo possibilitam aplicar a técnica mesmo na faixa de $\mu \mathrm{g} \mathrm{L}^{-1}$ (ZOUBOULIS, 1987).

\subsubsection{Flotação de precipitados}

Nessa técnica, é necessária a execução de uma etapa preliminar em que as espécies iônicas em questão são precipitadas e posteriormente flotadas com o uso de um coletor adequado. A eficiência da flotação de precipitados depende da hidrofobicidade dos precipitados formados, podendo ser atingida pela formação de 
um composto quelante insolúvel ou pela introdução de um surfactante. Por exemplo, o chumbo pode ser removido de uma solução diluída, precipitando-o como hidróxido e flotando o produto formado com o coletor dodecilamina (NERBITT; DAVIS, 1994).

\subsubsection{Flotação de colóides}

A flotação de colóides é similar à flotação de precipitados. Sendo que nesta técnica envolve a adição de um coagulante (cloreto ou sulfato de alumínio ou ferro) para produzir um floco. As espécies iônicas de interesse adsorvem-se na partícula floculada e/ou coprecipitada através de interações eletrostáticas. Um surfactante é adicionado adsorvendo a partícula floculada, tornando -a hidrofóbica. O floco contendo íons metálicos adsorvidos é removido por flotação. Por exemplo, o arsênio trivalente pode ser removido com sulfato férrico e/ou de alumínio. A hidrólise do sulfato férrico produz o hidróxido férrico (sólido), no qual o arsênio adsorve-se podendo ser removido (DUYVESTEYNEN, 1993).

A flotação apresenta simplicidade, flexibilidade e eficiência na sua operação, requer pouco espaço físico, gera um pequeno e concentrado volume de lama e pode ser utilizada em pequena, média e larga escala (NERBITT; E DAVIS, 1994).

\subsection{Eletroflotação}

A necessidade de se obter um método rápido e eficiente para atuar nessas separações vem motivando pesquisas para desenvolver métodos alternativos aos processos convencionais. A técnica da Eletroflotação (EF) mostra-se extremamente versátil e competitiva com as técnicas de sedimentação que requerem grandes

áreas e volumes para operação. É também competitiva em relação às outras técnicas de flotação, como flotação por ar dissolvido e flotação por ar disperso. As 
unidades de EF são menores e mais compactas, necessitam de menor manutenção e custo operacional que outras unidades de flotação (ZOUBOLIS; MATIS, 1995).

O reator de EF possui eletrodos de sacrifício como alumínio, por exemplo, que geram $\mathrm{Al}^{3+}$ devido ao potencial aplicado. Esta etapa faz parte do processo anódico, em que o alumínio metálico é oxidado. O cátion gerado na etapa anódica é hidrolizado formando o agente coagulante $\left(\mathrm{Al}(\mathrm{OH})_{3}\right)$ que será o responsável pela coagulação e formação das partículas coloidais.

O processo de EF depende principalmente da geração de gases hidrogênio e oxigênio durante a eletrólise da água. As bolhas de gás formadas na superfície dos eletrodos imersos na solução entram em contato com as partículas coloidais e, então, ascendem para a superfície do reator onde podem ser facilmente removidas (HOSNY, 1996).

A flotação do resíduo gerado, nesse processo apresenta-se bastante interessante do ponto de vista de simplicidade de automação com relativo baixo custo. Além disso, nesse processo não são gerados ânions sulfato, que poderiam vir a contaminar as águas do corpo receptor.

Com o estudo realizado podem ser apresentadas vantagens e desvantagens da utilização deste processo, de forma a contribuir para a tomada de decisão sobre sua implantação em uma unidade industrial (CRESPILHO; REZENDE, 2004).

\section{Vantagens:}

- Permite o atendimento à legislação ambiental com equipamentos de pequeno porte, utilizando área reduzida.

- Limita o uso de substâncias químicas minimizando o impacto negativo causado pelo excesso de xenobióticos lançados no ambiente, fato que acontece quando se emprega como tratamento a coagulação química. 
- O processo de EF remove as partículas coloidais menores, pois o campo elétrico aplicado promove o contato mais rapidamente entre elas, facilitando a coagulação.

- Há um controle maior na liberação do agente coagulante, em comparação com os processos convencionais.

\section{Desvantagens:}

- Os eletrodos são consumidos e necessitam de substituição regular.

- Necessita o uso de eletricidade.

- Um filme de óxido impermeável pode ser formado no cátodo, conduzindo à perda de eficiência da unidade de EF.

- Requer alta condutividade do efluente.

Nesse trabalho foi utilizado apenas eletrodos de alumínio, por isso foi destinada maior ênfase a esse metal.

A geração eletroquímica do agente coagulante é determinante para que a coagulação ocorra de maneira controlada e eficiente. No caso da geração de $\mathrm{Al}^{3+}$ a partir de um ânodo de alumínio, vários fatores têm que ser levados em consideração, como por exemplo, a condutividade da solução, a resistividade do meio, o potencial aplicado entre os eletrodos e a corrente obtida. De um modo geral, todos esses fatores estão relacionados entre si. Uma vez controlados, a geração do agente coagulante passa a ser monitorada pela corrente obtida.

A coagulação das partículas, ou seja, o alumínio carregado positivamente pode reagir com partículas de cargas negativas. Porém, esse tipo de reação fica limitado devido à hidrólise do alumínio carregado que, por sua vez, é muito rápida. É 
de grande interesse nessa etapa do processo que a hidrólise resulte em hidróxido de alumínio, $\mathrm{Al}(\mathrm{OH})_{3}$, uma vez que esse composto será o maior responsável pela remoção das impurezas da água. A seguir, têm-se as equações que descrevem as etapas da hidrólise do íon $\mathrm{Al}^{3+}$.

Oxidação do alumínio sólido (reação anódica)

$$
A l \rightarrow A l^{3+}+3 e^{-}
$$

Solvatação do cátion formado

$$
\mathrm{Al}^{3+}+6 \mathrm{H}_{2} \mathrm{O} \rightarrow \mathrm{Al}\left(\mathrm{H}_{2} \mathrm{O}\right)_{6}^{3+}
$$

Formação do agente coagulante

$$
\begin{aligned}
& \mathrm{Al}\left(\mathrm{H}_{2} \mathrm{O}\right)_{6}^{3+} \longrightarrow \mathrm{Al}(\mathrm{OH})_{3}(\mathrm{~s})+3 \mathrm{H}^{+} \\
& n \mathrm{Al}(\mathrm{OH})_{3} \longrightarrow \mathrm{Al}_{n}(\mathrm{OH})_{3 n}(\mathrm{~s}) \\
& 2 \mathrm{H}_{2} \mathrm{O} \longrightarrow \mathrm{O}_{2} \uparrow+4 \mathrm{H}^{+}+4 \mathrm{e}
\end{aligned}
$$

Oxigênio gerado em uma parte do eletrodo é muito reativo, favorecendo pela sua qualidade de oxidante a quebra de eventuais moléculas orgânicas.

Pode-se notar pela reação 4 que vários complexos de alumínio podem ser formados. A presença desses complexos em solução aquosa confere uma característica gelatinosa ao meio. Esses complexos podem ser efetivamente os responsáveis pela remoção de poluentes, principalmente por adsorverem-se aos mesmos formando coágulos maiores, os flocos. Porém, a estabilidade do hidróxido de alumínio depende do pH do meio (CRESPILHO; E REZENDE, 2004).

Na Figura 2, apresenta-se o diagrama de hidrólise do alumínio com os tipos de compostos em solução aquosa de acordo com o pH. 


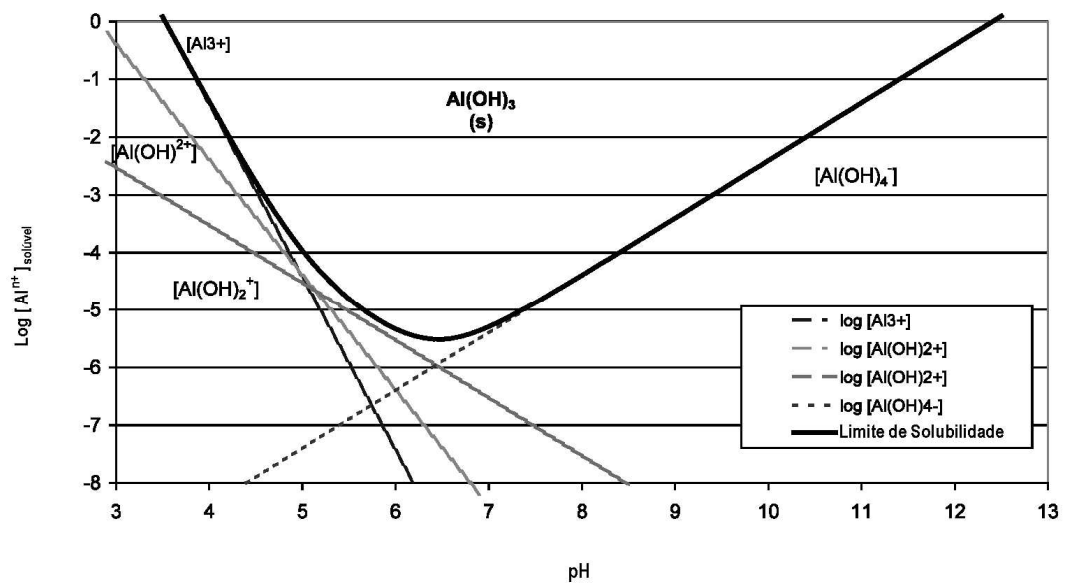

Figura 2: Solubilidade do alumínio em função do $\mathrm{pH}$ ( MOLLAH et al., 2001)

Na Figura 2 observa-se que, acima de $\mathrm{pH} 7$, complexos solúveis podem ser formados.

O conjunto de eletrodos é o seio do processo de EF. Os mais comuns são alumínio e ferro, pois são baratos, eficazes e prontamente disponíveis. As reações a seguir mostram como ocorre a geração de íons ferro em solução.

Oxidação do ferro sólido (reação anódica)

$\mathrm{Fe} \rightarrow \mathrm{Fe}^{2+}+2 \mathrm{e}$

Em, seguida, ocorre hidrólise desses íons em meio alcalino:

$$
\begin{aligned}
& \mathrm{Fe}^{2+}+2 \mathrm{OH}^{-} \rightarrow \mathrm{Fe}(\mathrm{OH})_{2} \\
& 2 \mathrm{Fe}(\mathrm{OH})_{2}+1 / 2 \mathrm{O}_{2}+\mathrm{H}_{2} \mathrm{O} \rightarrow 2 \mathrm{Fe}(\mathrm{OH})_{3} \text { ou } \mathrm{FeO} . \mathrm{OH}
\end{aligned}
$$

A hidrólise do $\mathrm{Fe}^{3+}$ também conduz à formação de várias espécies reativas para o tratamento de água. Os modelos estruturais para esse cátion ainda são resultado de muitas pesquisas em andamento. 
Os sólidos de $\mathrm{Fe}(\mathrm{OH})_{\mathrm{n}}$ formam uma suspensão gelatinosa que pode remover os poluentes do efluente por complexação ou atração eletrostática, seguida de coagulação.

Um dos problemas causados pelo uso do eletrodo de ferro é o efluente tratado apresentar coloração amarelada ou esverdeada em razão da presença de $\mathrm{Fe}^{2+}$ e $\mathrm{Fe}^{3+}$ remanescente. Os compostos de $\mathrm{Fe}^{2+}$ podem apresentar solubilidade elevada em circunstâncias ácidas ou neutras e podem ser oxidados facilmente a $\mathrm{Fe}^{3+}$ pelo oxigênio dissolvido na água. No caso do tratamento de efluentes de restaurantes, por exemplo, isto pode gerar problemas, porque a maioria deles não abre 24 horas por dia, ou seja, o processo é interrompido, criando condições necessárias para oxidar os eletrodos. Assim, para esse caso, obtêm-se resultados mais satisfatórios com o uso de eletrodo de alumínio (CRESPILHO; E REZENDE, 2004).

\subsubsection{Eletrofloculação}

Os complexos de hidróxido de alumínio formados adsorvem-se em partículas coloidais, dando origem a partículas maiores. Essa etapa, também chamada de floculação, consiste em uma maior estabilização do sistema e os flocos formados podem ser removidos por decantação, filtração ou flotação. Assim, a formação de flocos pode ser considerada como resultado de dois fenômenos: a hidrólise do alumínio que, por sua vez, depende do $\mathrm{pH}$ e da concentração final de $\mathrm{Al}^{3+}$ e o transporte das espécies hidrolisadas para promover o contato com as impurezas e, em seguida, a floculação. 
Tendo em vista uma floculação satisfatória, é preciso entender o sistema coloidal do tipo de efluente a ser tratado, para que os parâmetros que envolvem essa etapa possam ser controlados.

A ciência dos colóides ocupa-se com sistemas nos quais um ou mais componentes apresentam pelo menos uma de suas dimensões dentro do intervalo de $1 \mathrm{~nm}$ a $1 \mu \mathrm{m}$, ou seja, refere-se, essencialmente, a sistemas contendo tanto grandes moléculas como pequenas partículas (HUNTER,1993).

Os sistemas coloidais podem ser agrupados em três classificações gerais. As dispersões coloidais, que são termodinamicamente instáveis e classificadas como irreversíveis por não serem reconstituídas facilmente após a remoção das fases. As soluções verdadeiras de substâncias macromoleculares, que são termodinamicamente estáveis e classificadas como reversíveis por serem reconstituídas facilmente após a separação das fases. Por fim, os eletrólitos coloidais são termodinamicamente estáveis e conferem propriedades iônicas ao sistema, em se associando com outras estruturas mantendo a propriedade de formação de micelas (HUNTER, 1993).

A teoria desenvolvida por Derjaguin-Landau e Verwey (DLV) é a mais aceita e utilizada para explicar a floculação.

Essa teoria diz que a aproximação entre os colóides presentes em solução é conseqüência do movimento browniano das partículas. Quando dois colóides se aproximam, ocorre interação entre as camadas difusas, o que leva à repulsão em razão da força eletrostática entre os mesmos. Essa força de repulsão ocorre porque os colóides possuem cargas de mesmo sinal. Entretanto, elas sofrem ação de forças de van der Waals do tipo dipolo permanente e dipolo induzido, que atuam nos colóides, fazendo com que ocorra atração entre as partículas coloidais. Assim, o 
sistema que está em estágio de floculação é regido pela interação entre as forças de repulsão de origem elétrica e de atração do tipo van der Waals.

Quando as forças de repulsão são maiores que as de atração, o sistema está estável e não ocorre floculação. A energia potencial de repulsão é tanto maior quanto menor a distância entre as partículas. Quando a concentração iônica é baixa, a energia resultante é de repulsão, atinge um valor máximo, conhecido como barreira de energia (CRESPILHO; REZENDE, 2004).

Na Figura 4 é representada a ação das forças envolvidas no processo de aproximação entre dois colóides, quando o sistema possui baixa concentração iônica.

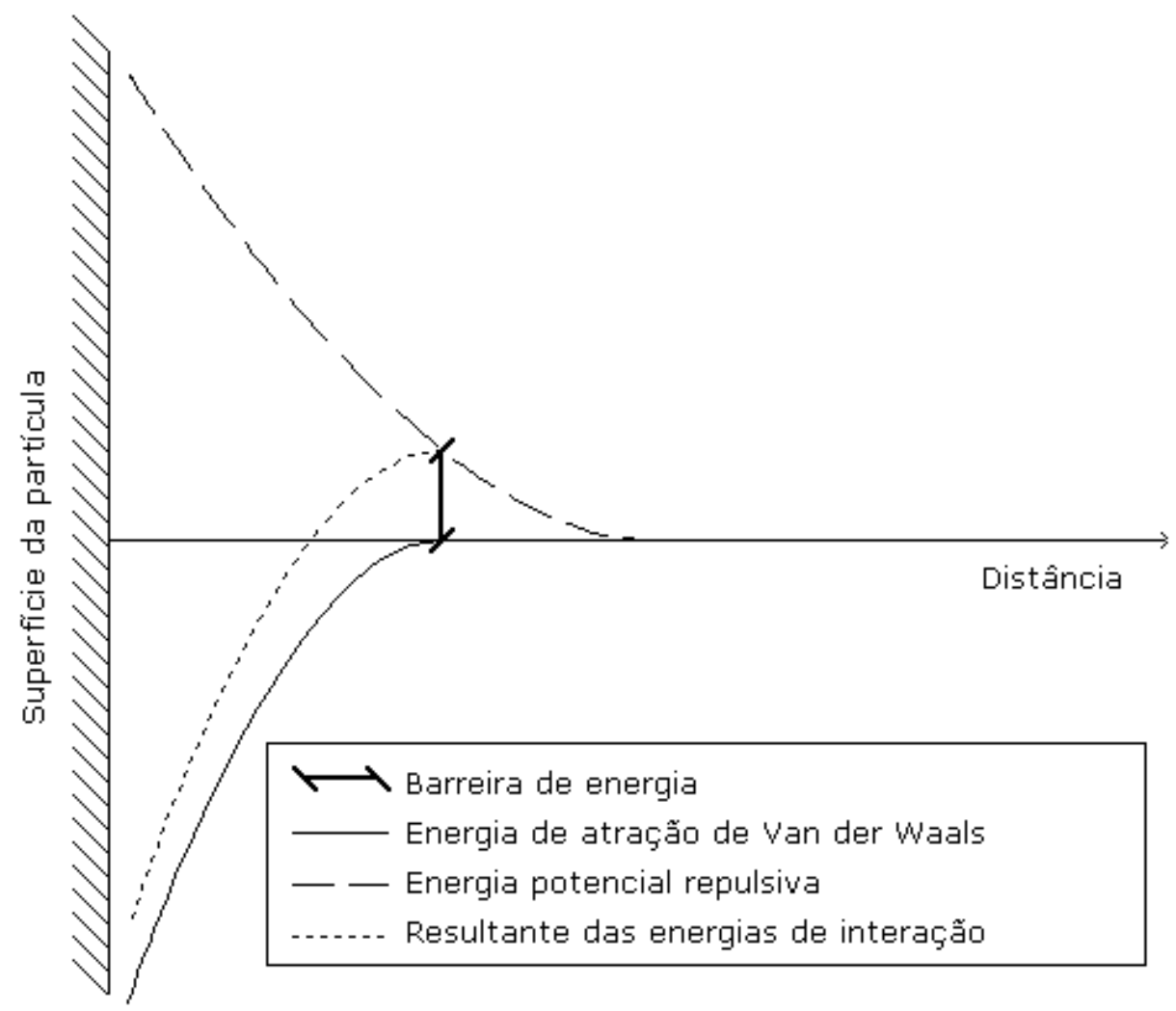

Figura4: Curva de energia de repulsão e de atração em função da distância entre duas partículas coloidais semelhantes em solução de baixa concentração iônica (extraído de CRESPILHO; E REZENDE, 2004) 
Quando a energia de atração é maior que a de repulsão, ocorre interação entre as partículas. Caso haja aumento da concentração iônica do meio, será possível ter a barreira de energia rompida e, então, o contato entre as partículas coloidais ocorrerá.

A barreira de energia origina-se na dupla camada elétrica, região em que ocorre concentração e distribuição de cargas em uma partícula coloidal. A configuração dessa camada envolve princípios que ainda são motivo de discussão. Nesse caso, o modelo proposto por Guy e Chapman e revisado por Verway e Overbeek possui bases satisfatórias para entender os fenômenos ocorrentes na camada difusa da dupla camada elétrica, cujo modelo é apresentado na Figura 5.

A introdução de um eletrólito estranho ao sistema coloidal provoca aumento da densidade de carga da camada difusa e diminui o tamanho da mesma, levando à coagulação das espécies envolvidas. Assim, quando a concentração iônica é relativamente elevada, ocorre aumento na concentração de íons da camada difusa, a qual, para permanecer eletricamente neutra, tem seu volume reduzido de forma que as interações de van der Waals sejam dominantes diante das forças eletrostáticas repulsivas. 


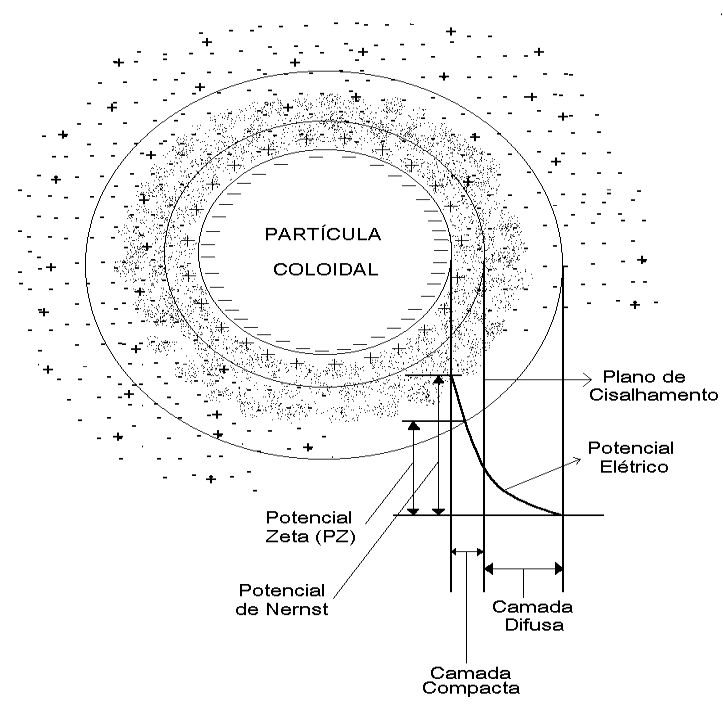

Figura5: Configuração esquemática da dupla camada elétrica (extraído de CRESPILHO ; REZENDE, 2004)

O potencial zeta, também chamado de potencial eletrocinético, pode ser utilizado para determinar a carga eletrostática da superfície das partículas coloidais. No início da camada difusa está o plano de cisalhamento, cujo potencial é o potencial zeta (CRESPILHO; REZENDE, 2004).

Devido ao potencial aplicado, micro-bolhas de hidrogênio podem ser formadas no cátodo, conforme a equação 5.

$$
2 \mathrm{H}_{2} \mathrm{O}+2 \mathrm{e}^{-} \rightarrow \mathrm{H}_{2}+2 \mathrm{OH}^{-}
$$

As micro-bolhas geradas auxiliam a flotação dos colóides formados na etapa anterior.

A Figura 6 mostra, respectivamente, o esquema do processo eletrolítico, uma vista do reator de laboratório e os eletrodos usados na eletrocoagulação. $\mathrm{Na}$ 
eletroflotação as micro-bolhas são geradas a partir de reações eletroquímicas promovendo a remoção de contaminantes.

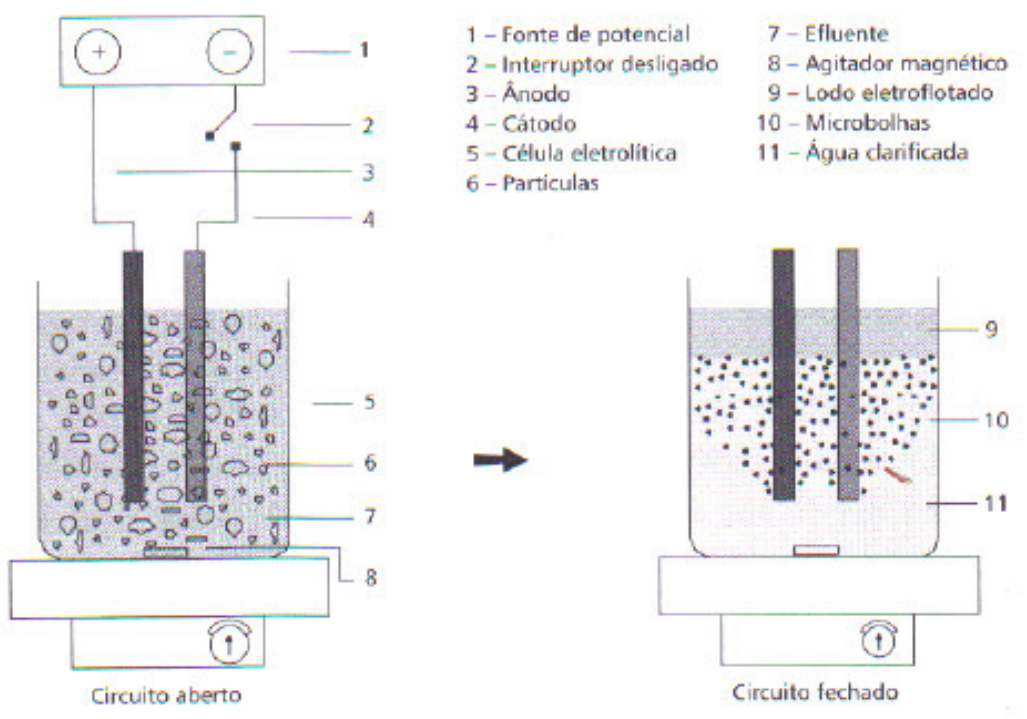

Figura 6: Reator eletrolítico de bancada promovendo a separação por flotação (extraído de CASQUEIRA; E TOREM, 2002)

Caso o efluente contenha íons cloreto, pode-se formar $\mathrm{Cl}_{2}$ no ânodo, que, na presença de água, poderá formar íons hiploclorito. Esse fato pode ser considerado como uma grande vantagem da EF, uma vez que a geração de cloro pode participar da desinfecção da água como eliminar odores indesejáveis (BERNARDO,1993).

\subsubsection{Fenômenos associados com a EF}

A quantidade de substâncias produzidas pelo processo eletrolítico é proporcional à quantidade de elétrons envolvidos durante a eletrólise e para um dado valor de consumo de eletricidade, a quantidade de substâncias produzidas é proporcional ao número de mols do material do eletrodo.

A massa de eletrodo consumido $\left(\mathrm{Mel}_{\mathrm{el}}\right)$, em gramas, durante a $\mathrm{EF}$, pode ser calculada pela equação 6 . 


$$
M_{e l}=\frac{i \times t \times m}{F \times n e^{-}}
$$

onde, $\mathrm{i}=$ corrente $(\mathrm{A}) ; \mathrm{t}=$ tempo de aplicação da corrente $(\mathrm{s}) ; \mathrm{m}=$ massa atômica do elemento predominante do eletrodo $\left(\mathrm{g} \mathrm{mol}^{-1}\right) ; \mathrm{ne}^{-}=$número de elétrons envolvidos na reação de oxidação do elemento do ânodo (ne'Al = 3) e F = constante de Faraday $\left(9,65 \times 10^{4} \mathrm{C}\right.$ mol).

Esta informação é muito importante, pois, a partir deste cálculo, conhecendose a quantidade de íons do metal necessária para promover a coagulação das impurezas, é possível estabelecer a corrente a ser aplicada para um intervalo de tempo pré-determinado, e a área dos eletrodos que participarão da eletrólise para uma expectativa desejada de vida útil desses eletrodos.

Assim, por meio da corrente aplicada pode-se determinar a potência em unidades de $\mathrm{kW} \mathrm{h} \mathrm{m}{ }^{-3}$ de um reator eletrolítico em fluxo contínuo, de acordo com a equação abaixo (CRESPILHO; REZENDE, 2004):

$$
\begin{aligned}
& \mathrm{P}=(\mathrm{U} \times \mathrm{i}) /(\mathrm{Q} \times 100) \text {, onde: } \\
& \mathrm{i}=\text { corrente aplicada na eletrólise }(\mathrm{A}) \\
& \mathrm{U}=\text { potencial }(\mathrm{V}) \\
& \mathrm{Q}=\text { fluxo }\left(\mathrm{m}^{3} / \mathrm{h}\right)
\end{aligned}
$$

Se a distância entre os eletrodos for muito grande, ocorrerá a perda de energia por dissipação, ocorrendo um aumento da diferença de potencial. Efeito 
semelhante ocorre se houver depósito de matéria orgânica sobre os eletrodos (principalmente sobre o ânodo), ou pela formação de camada de óxidos sobre o cátodo (passivação). Se a corrente aplicada nos eletrodos for muito alta pode ocorrer formação de bolhas de hidrogênio em excesso, ocorrendo passivação do cátodo. Isto pode ser evitado pelo controle da corrente, pela agitação da mistura a ser eletrocoagulada, ou pela inversão dos pólos dos eletrodos, limpando o cátodo. As reações que explicam a eletrólise dependem do $\mathrm{pH}$ do meio, da condutividade e tipo de sais dissolvidos, da diferença de potencial aplicada entre os eletrodos, da corrente específica, do tempo de retenção na câmara de eletrocoagulação, da natureza da composição presente na solução ou suspensão a ser tratada, do material componente dos eletrodos e do formato da câmara de eletrocoagulação (MOLLAH et al., 2001).

\subsubsection{Trabalhos envolvendo a Eletroflotação}

A EF tem se mostrado um dos processos mais próspero, no que se refere à aplicação e desenvolvimento de diferentes tipos de reatores para pré- tratamento de efluentes industrias.

Alguns pesquisadores, como mostra a Tabela 1, estudaram 0 desenvolvimento do tema eletrocoagulação/eletroflotação abordando diferentes metodologias e objetivos. Dentre os países que investem na EF, podem-se destacar os EUA, Taiwan, China e atualmente a Tunísia.

No Brasil, recentemente, pode-se citar a aplicação da EF no tratamento de efluente da indústria de coco realizado por Crespilho (2004) e na remoção de metais, desenvolvido por Casqueira et al. (2006). 
Os trabalhos que envolvem a EF estão apresentados em ordem cronológica na Tabela1.

TABELA 1- Cronologia dos trabalhos envolvendo EF

\begin{tabular}{|c|c|c|c|}
\hline Ano & Autor & País & Título do trabalho \\
\hline $1889^{\star}$ & Strokach & R.Unido & $\begin{array}{l}\text { Primeiro trabalho:eletricidade } \\
\text { no tratamento de água }\end{array}$ \\
\hline $1909^{*}$ & - & EUA & $\begin{array}{l}\text { Primeira patente: EF com } \\
\text { eletrodos de ferro e alumínio }\end{array}$ \\
\hline $1946^{\star}$ & - & EUA & $\begin{array}{l}\text { Aplicação da EF em larga } \\
\text { escala no tratamento de água }\end{array}$ \\
\hline $1995^{\star}$ & Matteson et al. & EUA & $\begin{array}{l}\text { Remoção de partículas } \\
\text { ultrafinas }\end{array}$ \\
\hline $1996^{*}$ & Hosny & Egito & Remoção de óleos \\
\hline 1996* & Tsai et al. & China e Taiwan & $\begin{array}{l}\text { Remoção de matéria orgânica } \\
\text { solúvel em água }\end{array}$ \\
\hline $1997^{\star}$ & Burns et al. & EUA & $\begin{array}{l}\text { Estudo das microbolhas } \\
\text { produzidas durante a EF }\end{array}$ \\
\hline $1997^{\star}$ & Poo & EUA & $\begin{array}{l}\text { Remoção de metais em águas } \\
\text { residuárias }\end{array}$ \\
\hline $1997^{\star}$ & Rurbach e Saur & $\begin{array}{l}\text { França e } \\
\text { Noruega }\end{array}$ & $\begin{array}{l}\text { Remoção de hidrocarbonetos } \\
\text { em água }\end{array}$ \\
\hline 1998* & Lin e Lin & Taiwan & $\begin{array}{lll}\text { Tratamento de } & \text { águas } \\
\text { contaminadas com fibras } \\
\text { vegetais }\end{array}$ \\
\hline 1999* & Chen et al. & China & $\begin{array}{l}\text { Tratamento de efluentes de } \\
\text { restaurantes }\end{array}$ \\
\hline 1999* & Picard et al. & França & $\begin{array}{l}\text { Descoberta do fenômeno de } \\
\text { dissolução catódica na EF }\end{array}$ \\
\hline 1999* & $\begin{array}{l}\text { Kovatcheva et } \\
\text { al. }\end{array}$ & Bulgária & $\begin{array}{l}\text { Estudo da } \\
\text { eletrocoagulação }\end{array}$ \\
\hline $2000^{*}$ & Ciardele e & Itália & EF com ozonólise para o \\
\hline
\end{tabular}




\begin{tabular}{|c|c|c|c|}
\hline & Raniere & & tratamento de efluentes têxteis \\
\hline 2000* & Ciorba & Romênia & Remoção de surfactantes \\
\hline $2001^{*}$ & Mollah et al. & EUA & $\begin{array}{l}\text { Estudo sobre a ciência e } \\
\text { aplicação da EF }\end{array}$ \\
\hline $2001^{*}$ & Tesoures et al. & EUA & $\begin{array}{l}\text { Aplicação da EF com remoção } \\
\text { magnética }\end{array}$ \\
\hline $2001^{*}$ & Xiong et al. & China & Remoção de corantes \\
\hline $2001^{\star}$ & Mameri et al. & Argélia/Canadá & Remoção de flúor \\
\hline $2002^{*}$ & Holt et al. & Austrália & $\begin{array}{l}\text { Comparação entre a EF e a } \\
\text { dosagem química }\end{array}$ \\
\hline $2002^{*}$ & Chen et al. & China & $\begin{array}{l}\text { Investigação do efeito do } \\
\text { potencial na EF }\end{array}$ \\
\hline $2002^{*}$ & Gurses et al. & Turquia & $\begin{array}{l}\text { Variáveis eletroquímicas para } \\
\text { a remoção de corantes }\end{array}$ \\
\hline $2002^{*}$ & Dneshevar et al. & Irã & Remoção de corantes \\
\hline $2002^{*}$ & $\begin{array}{l}\text { Koparal e } \\
\text { Ogutveren }\end{array}$ & Turquia & Remoção de nitrato \\
\hline $2002^{*}$ & Jeang et al. & R. Unido & Tratamento de água \\
\hline $2003^{\star}$ & Feng et al. & Japão & $\begin{array}{l}\text { Desenvolvimento de uma } \\
\text { umidade piloto de EF }\end{array}$ \\
\hline $2003^{\star}$ & Hu et al. & Taiwan & $\begin{array}{l}\text { Estudo dos fenômenos } \\
\text { coexistentes na remoção de } \\
\text { flúor }\end{array}$ \\
\hline $2003^{*}$ & $\begin{array}{l}\text { Bezerra-Diáz et } \\
\text { al. }\end{array}$ & México & $\begin{array}{l}\text { Processo combinado EF e } \\
\text { irradiação }\end{array}$ \\
\hline $2003^{\star}$ & Chen e Lin & Taiwan & Remoção de cobre \\
\hline $2003^{*}$ & Kobya & Turquia & $\begin{array}{l}\text { Remoção de corante do } \\
\text { efluente da indústria têxtil }\end{array}$ \\
\hline $2003^{*}$ & Shen et al. & China & Remoção de fluoretos \\
\hline $2003^{\star}$ & Laure et al. & Fança & $\begin{array}{l}\text { Remoção de partículas de } \\
\text { látex em suspensão }\end{array}$ \\
\hline $2003^{*}$ & $\begin{array}{l}\text { Laure e } \\
\text { Vorobiev }\end{array}$ & França & $\begin{array}{l}\text { Tamanho das partículas na EF } \\
\text { com eletrodo de ferro }\end{array}$ \\
\hline
\end{tabular}




\begin{tabular}{|c|c|c|c|}
\hline $2003^{\star}$ & Crespilho et al. & Brasil & $\begin{array}{l}\text { Estudo da EF com câmara de } \\
\text { mistura rápida }\end{array}$ \\
\hline $2003^{\star}$ & Crespilho et al. & Brasil & $\begin{array}{l}\text { Patente EF/Flotação por ar } \\
\text { dissolvido(Eletro FAD) }\end{array}$ \\
\hline $2004^{\star}$ & Kumar et al. & Índia & Remoção de arsênio \\
\hline $2004^{\star}$ & $\begin{array}{l}\text { Bergmannet et } \\
\text { al. }\end{array}$ & $\begin{array}{l}\text { Alem/Rep } \\
\text { Checa }\end{array}$ & $\begin{array}{l}\text { Remoção de óleos } \\
\text { lubrificantes }\end{array}$ \\
\hline $2004^{\star}$ & $\begin{array}{l}\text { Adhoum e } \\
\text { Monser }\end{array}$ & Tunísia & Remoção de polifenóis \\
\hline 2004* & Chen & China & $\begin{array}{l}\text { Tecnologia e tipos de reatores } \\
\text { utilizados em EF }\end{array}$ \\
\hline $2004^{\star}$ & Crespilho et al. & Brasil & $\begin{array}{l}\text { Tratamento do efluente da } \\
\text { indústria de coco }\end{array}$ \\
\hline $2004^{\star}$ & Crespilho et al. & Brasil & $\begin{array}{l}\text { Comparação entre EF e a } \\
\text { sedimentação }\end{array}$ \\
\hline $2004^{\star}$ & Ge et al. & China & $\begin{array}{l}\text { Tratamento de efluente de } \\
\text { lavanderias }\end{array}$ \\
\hline 2005 & Khelifa et al & Algéria & $\begin{array}{l}\text { Tratamento de efluentes com } \\
\text { metais por EF }\end{array}$ \\
\hline 2006 & Casqueira et al. & Brasil & A remoção de zinco por EF \\
\hline 2006 & $\begin{array}{c}\text { Ben Mansour et } \\
\text { al. }\end{array}$ & Tunísia & $\begin{array}{l}\text { Tratamento de águas residuais } \\
\text { da indústria papeleira por } \\
\text { coagulação-EF }\end{array}$ \\
\hline 2006 & Khoufi et al. & Tunísia & $\begin{array}{l}\text { Desintoxicação em águas } \\
\text { residuais por eletrocoagulação } \\
\text { e sedimentação }\end{array}$ \\
\hline 2007 & $\begin{array}{c}\text { Moreno- } \\
\text { Cassalis et al. }\end{array}$ & México & $\begin{array}{l}\text { Mecanismo para a remoção da } \\
\text { DQO por Eletrocoagulação }\end{array}$ \\
\hline 2007 & Essadki et al. & $\begin{array}{c}\text { Marrocos/Franç } \\
\text { a }\end{array}$ & $\begin{array}{l}\text { Aplicação da } \\
\text { eletrocoagulação-EF em águas } \\
\text { residuais de corante têxtil. }\end{array}$ \\
\hline 2007 & Mouedhen et al. & Tunísia/França & $\begin{array}{l}\text { Comportamento do eletrodo de } \\
\text { alumínio no processo de EF }\end{array}$ \\
\hline
\end{tabular}




\begin{tabular}{|c|c|c|c|}
\hline 2007 & Bande et al. & India & $\begin{array}{l}\text { Tratamento de água contendo } \\
\text { petróleo por EF }\end{array}$ \\
\hline 2007 & Canizares et al. & México/EUA & $\begin{array}{l}\text { Coagulação } \\
\text { eletrocoagulação em águas } \\
\text { contendo óleos e emulsões }\end{array}$ \\
\hline
\end{tabular}

*Informações extraídas da Ref: (CRESPILHO, 2004) 
OBJETIVOS 


\section{Objetivos:}

O trabalho teve como objetivo avaliar a eficiência da EF no tratamento do resíduo de fluido de corte sintético, a base de "polialquileno glicol".

Para diagnosticar a eficiência da EF na remoção dos contaminantes presentes no fluido de corte foram realizadas algumas caracterizações antes e após o tratamento. Os resultados foram comparados com alguns dos valores pertinentes na Legislação Estadual do estado de São Paulo (Decreto nº 8.468, de 8 de setembro de 1976) para descarte de efluentes. 
FUNDAMENTOS E

METODOLOGIAS 


\section{PARÂMETROS ESTUDADOS: FUNDAMENTOS E METODOLOGIAS}

O tratamento realizado teve como finalidade propor 0 descarte ambientalmente correto do resíduo em estudo.

O resíduo de fluido de corte foi cedido pelo Núcleo de Manufatura Avançada NUMA da Escola de Engenharia de São Carlos - EESC-USP. Os parâmertros de qualidade utilizado foram:

- Condutividade

- Sólidos totais

- Turbidez

- $\mathrm{pH}$

- Metais

- Óleos e graxas

- Carbono orgânico total

- Fósforo total

- Nitritos

- DBO (Demanda bioquímica de oxigênio)

- DQO (Demanda química de oxigênio)

- HPAs (Hidrocarbonetos policíclicos aromáticos)

- BTEX (benzeno, tolueno etilbenzeno e xilenos)

\subsection{Sistema de Eletroflotação:}

O sistema de EF pode ser do tipo em batelada ou em fluxo contínuo. Para os sistemas em batelada, o próprio reator de EF funciona como câmara de coagulação e separação. No processo em fluxo contínuo várias etapas estão associadas, desde 
o bombeamento do efluente para dentro do reator, até sua saída para uma câmara de separação.

No presente trabalho foi utilizado um sistema em batelada com 5 eletrodos de alumínio como mostra a Figura 7 com dimensões: 135 x45 x2,5mm (comprimento x largura x espessura). As placas de alumínio foram adquiridas da oficina mecânica do Instituto de Química de São Carlos-USP.

Os eletrodos de alumínio utilizado foram do tipo 10XX. Pelo sistema de classificação, a série $1 \mathrm{XXX}$ significa o alumínio comercialmente puro em diferentes graus de pureza, desde 99,00\% (denominado 1000) até 99,99\% (denominado 1099) (LEITE,1996).

Os eletrodos foram ligados em uma fonte do tipo conversor CA/CC da marca Tecnovolt Minitec RMF 20 e adaptada ao sistema uma bomba peristáltica para entrada do efluente. O reator utilizado foi RF1 patenteado (CRESPILHO e REZENDE, 2005).

No resíduo foi adicionado cloreto de sódio (0,5g/L) para aumentar a condutividade do mesmo, afim de melhorar o processo de eletroflotação.

Na Figura 8 é mostrado o sistema eletroquímico utilizado para o tratamento do fluido de corte. O fluido de corte sintético não tratado foi bombeado para dentro do reator com auxílio de uma bomba mantendo uma vazão constante, e completado o volume de $550 \mathrm{~mL}$ o reator foi vedado e iniciou-se o processo de EF. Não houve nenhum sistema de agitação devido a geometria do reator. Todo processo foi controlado utilizando dois multímetros para verificação da corrente aplicada e o potencial gerado para melhor tratamento do fluido de corte. 


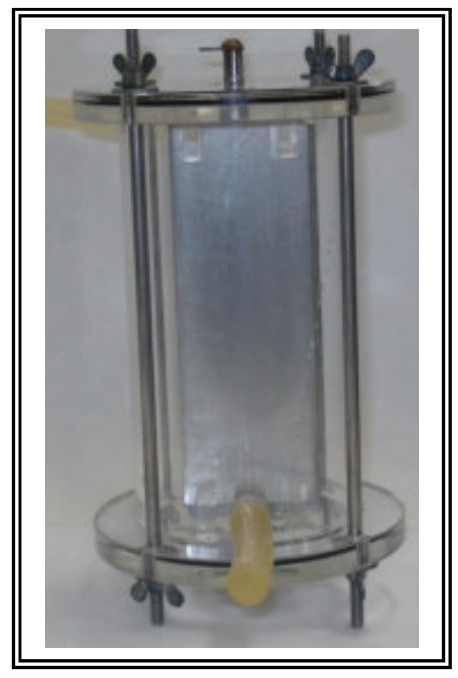

Figura 7: Imagem fotográfica do reator eletroquímico.

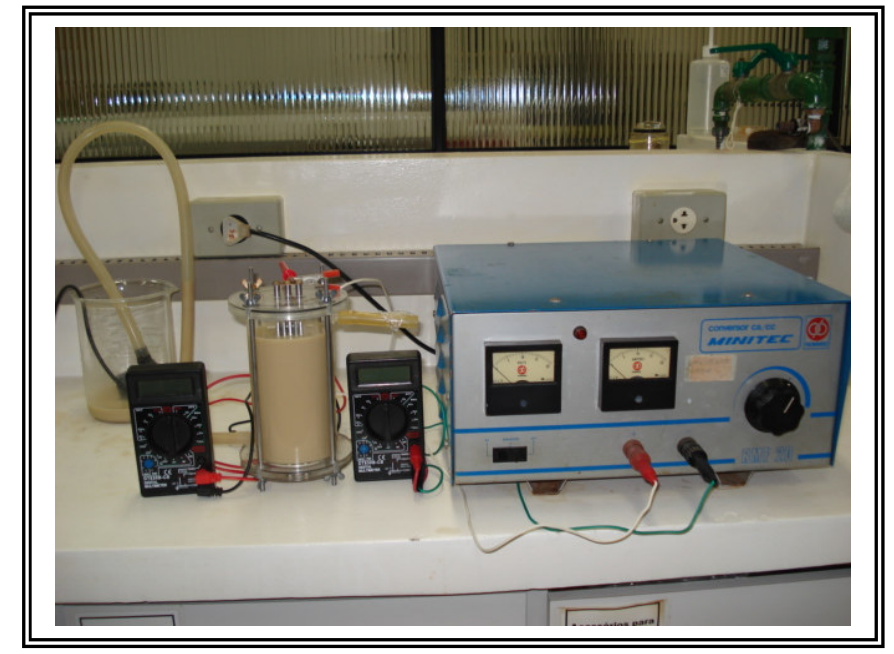

Figura 8: Imagem fotográfica do sistema eletroquímico.

\subsection{Parâmetros utilizados no tratamento com EF}

Foram avaliados os parâmetros como corrente elétrica aplicada, potência do reator, gastos com energia elétrica e tempo de tratamento, baseados na determinação do pH, sólidos totais dissolvidos e quantidade de lodo gerado após vários processos de EF. 
Após estabelecida a melhor corrente a ser aplicada no tratamento do fluido de corte em estudo, foi verificado a inversão da polaridade da mesma visando um melhor tratamento.

\subsection{Métodos de Caracterização}

A caracterização verificou a qualidade do fluido de corte antes e após o processo de EF, bem como o lodo gerado no tratamento.

Foi realizada uma varredura para identificar os metais presentes no EB. Foram determinadas as concentrações de $\mathrm{Fe}, \mathrm{Al}, \mathrm{Zn}, \mathrm{Cu}, \mathrm{Ni}, \mathrm{Pb}$ e $\mathrm{Mn}$.

Foram determinados a condutividade, sólidos totais, turbidez, $\mathrm{pH}$, metais pesados, óleos e graxas, carbono orgânico total, fósforo total, nitritos, $\mathrm{DBO}_{5}, \mathrm{DQO}$, HPAs , BTEX e nitrosaminas.

Todas as determinações foram realizadas em triplicata, com o cálculo do desvio da média.

\subsubsection{Determinação de Metais}

Alguns metais são essenciais para o crescimento de plantas e animais enquanto outros podem afetar seriamente os consumidores e receptores de águas.

O potencial de toxicidade dos metais depende de uma variedade de fatores que influenciam a disponibilidade destes para os organismos, incluindo a forma e concentração em que eles se encontram. Por sua vez, a forma em que os metais se encontram varia de acordo com as alterações ambientais, tais como mudanças de $\mathrm{pH}$, teor e composição de matéria orgânica, teor de oxigênio, teor de salinidade entre outros (ADAMS, 1995; ZAMBETTA, 2006). 
Os efluentes de qualquer fonte poluidora somente poderão ser lançados em sistema de esgotos, provido de tratamento. Assim, são apresentados os limites de lançamentos na Tabela 2.

Tabela 2: Concentrações limites de metais para lançamentos de efluentes (Decreto no 8.468 de 08/09/1976 da Legislação Estadual SP)

\begin{tabular}{cc}
\hline Padrões & Valor máximo para lançamento (mg/L) \\
\hline Cd total & 1,5 \\
Pb total & 1,5 \\
Cu dissolvido & 1,5 \\
Cr total & 5,0 \\
Fe dissolvido & 15 \\
Mn dissolvido & 1,0 \\
Ni total & 2,0 \\
Zn total & 5,0 \\
Al & Não consta \\
Ag total & 0,1 \\
\hline
\end{tabular}

$\mathrm{Na}$ determinação de metais utilizou-se a técnica de Espectroscopia de Emissão por Plasma Indutivamente Acoplado (ICP-AES) pois aplica-se a um grande número de metais, principalmente para os chamados refratários (que formam óxidos estáveis e não decompõem facilmente com a temperatura da chama). É uma técnica amplamente utilizada em análise ambiental pois tem baixa vulnerabilidade para os interferentes interelementares em comparação com a técnica de Espectrometria de Absorção Atômica (THOMPSON, 1987).

Uma das vantagens da emissão atômica é a capacidade de realizar análises multielementares rápida que permite análises traços dos metais constituintes da amostra. 
Os metais dissolvidos são determinados em amostras filtradas e acidificadas, depois de uma digestão apropriada.

Primeiramente, realizou-se a digestão ácida das amostras pelo método 3005A da Environmental Protection Agency (EPA,1996).

Adicionou-se ao tubo digestor $100 \mathrm{~mL}$ da amostra com $2 \mathrm{~mL}$ de ácido nítrico concentrado e $10 \mathrm{~mL}$ de ácido clorídrico concentrado e aqueceu-se a uma temperatura a $95^{\circ} \mathrm{C}\left( \pm 5^{\circ} \mathrm{C}\right)$ e fez-se o refluxo até o volume da mistura ser reduzido a aproximadamente $15 \mathrm{~mL}$. Resfriou-se a mistura, adicionou-se água milli-pore completando o volume para $100 \mathrm{~mL}$ com o auxílio de um balão volumétrico e, filtrouse em papel de filtro, estando esta pronta para análise por ICP-AES. Para tal, utilizou-se um equipamento da marca Perkin Elmer, modelo Optima 3000.

O equipamento utilizado disponibiliza a escolha das linhas de emissão a serem utilizadas para cada elemento. A determinação dos metais foi realizada pelo método gráfico analítico, utilizando soluções padrões multielementares como mostra a Tabela 3. As condições do equipamento são:

Fluxo dos gases:

- Gás refrigerante Ar: $15 \mathrm{Lmin}^{-1}$

- Gás auxiliar $\mathrm{Ar}: 0,5 \mathrm{Lmin}^{-1}$

- Gás nebulizador Ar: 0,8 $\mathrm{Lmin}^{-1}$

- Potência do plasma: $1300 \mathrm{~W}$

- Fluxo amostra: $1 \mathrm{mLmin}^{-1}$ 
Tabela 3: Condições espectrométrica para determinação de metais

\begin{tabular}{ccc}
\hline Metal & $\begin{array}{c}\text { Faixa de concentração } \\
\left(\mathrm{mgL}^{-1}\right)\end{array}$ & $\begin{array}{c}\text { Comprimento de onda } \\
\text { utilizado }(\mathrm{nm})\end{array}$ \\
\hline $\mathrm{Al}$ & 0,$0 ; 5,0 ; 10 ; 30 ; 40$ & 309,271 \\
$\mathrm{Cd}$ & 0,$0 ; 0,05 ; 0,5 ; 1,0 ; 5,0 ; 10,0$ & 214,438 \\
$\mathrm{~Pb}$ & 0,$0 ; 0,05 ; 0,5 ; 1,0 ; 5,0 ; 10$ & 216,999 \\
$\mathrm{Cu}$ & 0,$0 ; 0,05 ; 0,5 ; 1,0 ; 5,0 ; 10$ & 224,700 \\
$\mathrm{Cr}$ & 0,$0 ; 0,05 ; 0,5 ; 1,0 ; 5,0 ; 10$ & 205,560 \\
$\mathrm{Fe}$ & 0,$0 ; 0,05 ; 0,5 ; 1,0 ; 5,0 ; 10$ & 239,562 \\
$\mathrm{Mn}$ & 0,$0 ; 0,05 ; 0,5 ; 1,0 ; 5,0 ; 10$ & 260,569 \\
$\mathrm{Ni}$ & 0,$0 ; 0,05 ; 0,5 ; 1,0 ; 5,0 ; 10$ & 232,003 \\
$\mathrm{Zn}$ & 0,$0 ; 0,05 ; 0,5 ; 1,0 ; 5,0 ; 10$ & 213,000 \\
\hline
\end{tabular}

Segundo Thompson (1987), o limite de deteç̧ão (LOD) do instrumento é definido como a concentração do analito que fornece uma resposta igual a três vezes o valor do desvio padrão do branco, que foi obtido através de 3 leituras simultâneas de água ultrapura acidificada com $\mathrm{HNO}_{3}$ 2\%. O limite de quantificação (LOQ), que corresponde a menor quantidade do analito que pode ser quantificada com exatidão e fidelidade determinada, foi determinado multiplicando seis vezes 0 valor do desvio padrão da leitura do branco.

\subsubsection{Verificação da adsorção de metais nos eletrodos de alumínio}

Após estabelecido os parâmetros do processo de EF para o tratamento do resíduo, verificou-se a possibilidade de haver adsorção de metais nos eletrodos.

$\mathrm{O}$ experimento foi realizado com água ultra purificada no processo de EF utilizando a mesma corrente e tempo de tratamento para o fluido de corte em estudo, porém com a polaridade invertida. 
Com a inversão da polaridade o eletrodo que se comportava como ânodo passa a liberar hidrogênio para o meio como mostra a página 28 , fazendo com que espécies metálicas aderidas aos eletrodos possam-se desprender para o meio.

A finalidade desse experimento foi remover os metais adorvidos nos eletrodos, durante os processos de EF com o resíduo, para a água. Em seguida analisou-se a presença de metais na água por ICP-AES.

\subsubsection{Determinação de sólidos totais, óleos e graxas e carbono orgânico total Sólidos Totais Dissolvidos (TDS)}

Nos estudos de controle de poluição das águas naturais e principalmente nos estudos de caracterização de esgotos sanitários e de efluentes industriais, as determinações dos níveis de concentração das diversas frações de sólidos resultam em um quadro geral da distribuição das partículas com relação ao tamanho (sólidos em suspensão e dissolvidos) e com relação à natureza (fixos ou minerais e voláteis ou orgânicos). A concentração de sólidos totais obtida refere-se quantidade de substâncias orgânicas e inorgânicas em solução, por isso é de grande importância a sua determinação (CETESB, 2006).

Foi determinada a concentração de sólidos totais dissolvidos a partir de $20 \mathrm{~mL}$ do resíduo.

O resíduo filtrado foi sujeito à evaporação $\left(105-110^{\circ} \mathrm{C}\right)$ durante uma hora em um cadinho de porcelana previamente aferido. Em seguida, a amostra foi transferida para um dessecador e, após 30 min, foi submetida à pesagem.

\section{Óleos e graxas}

Para a determinação de óleos e graxas em resíduos industriais, a EPA recomenda o método de Partição Gravimétrica. Com esse método não é possível 
dizer que uma quantidade específica de uma determinada substância foi extraída do resíduo e sim, uma somatória de diversos compostos com características físicas semelhantes. Uma alíquota do resíduo é misturada com uma certa quantidade de solvente orgânico, na qual o soluto (óleos e graxas, por exemplo) passa a se dissolver na fase orgânica. Para um soluto dissolver-se em um solvente, ele precisa ter uma interação com o solvente igual ou superior às interações solvente-solvente e soluto-soluto. Compostos orgânicos são, em geral, mais solúveis em solventes orgânicos e pouco solúveis em água. O coeficiente de distribuição (KD) é a constante de equilíbrio para a solubilidade de um composto em um solvente $A$ e um solvente $B$.

Então tem-se:

$$
\mathrm{KD}=\mathrm{CA} / \mathrm{CB}
$$

Onde CA e CB são as solubilidades do composto nos solventes $A$ e $B$, respectivamente.

Um valor alto de KD indica que grande parte do soluto irá ser transferida para o solvente A. Mesmo em casos em que KD é bastante alto, é conveniente realizarem-se sucessivas extrações (extrações múltiplas), em vez de uma simples extração (BERTAZZOLI; PELEGRINE, 2002)

O procedimento a seguir descreve as etapas realizadas com nível de

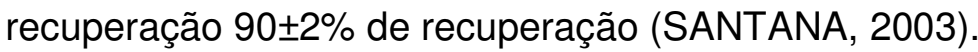

Primeiramente, transferiram-se $25 \mathrm{~mL}$ de uma amostra de efluente para um balão de fundo chato capacidade para $100 \mathrm{~mL}$, adicionando-se $2,5 \mathrm{~mL}$ de ácido nítrico concentrado e $2,5 \mathrm{~mL}$ de peróxido de hidrogênio.A mistura foi levada a rotoevaporação a $80^{\circ} \mathrm{C}$, deixando-se digerir até um volume final de aproximadamente $5 \mathrm{~mL}$. 
Após atingir a temperatura ambiente, tranferiru-se a amostra para um balão volumétrico de $25 \mathrm{~mL}$ previamente calibrado e completou-se o volume até o menisco.

Em seguida, a amostra foi transferida para um funil de separação de $250 \mathrm{~mL}$ onde se adicionaram $25 \mathrm{~mL}$ de $\mathrm{n}$-hexano p.a; agitou-se por 2 minutos e deixou-se o sistema em repouso por 2 horas. Após a separação das fases, a fase orgânica foi submetida à extração por mais duas vezes. $O$ volume final de $n$-hexano $(75 \mathrm{~mL})$ foi levado a roto-evaporação $\left(55^{\circ} \mathrm{C}\right)$ em um balão de fundo chato com sua massa previamente determinada (mi). Após a evaporação do solvente, o balão foi levado à estufa à $105^{\circ} \mathrm{C}$ onde permaneceu por 1 hora. Transferiu-se 0 balão para 0 dessecador e após o resfriamento do mesmo, determinou-se novamente a massa do balão (mf).

Para determinar a concentração de óleos e graxas presente no efluente (COG), utilizou-se a Eq.(x).

$$
\mathrm{COG}(\mathrm{mg} / \mathrm{L})=(\mathrm{mf}-\mathrm{mi}) \times 1000 / \mathrm{Va}
$$

Onde Va é o volume da amostra $(25 \mathrm{~mL})$.

\section{Determinação de carbono orgânico total (COT)}

O carbono orgânico em águas e águas residuárias é constituído de uma variedade de compostos orgânicos em vários estados de oxidação. Alguns desses compostos de carbono podem ser oxidados por processos biológicos ou químicos e os métodos de Demanda Bioquímica de Oxigênio (DBO), e Demanda Química de Oxigênio (DQO) podem ser usados para caracterizar essas frações.

Diferentemente do DBO e DQO, o COT é independente do estado de oxidação da matéria orgânica e não mede outros elementos ligados a compostos 
orgânicos, como nitrogênio e hidrogênio, e inorgânicos que podem contribuir para a demanda de oxigênio nas determinações de DBO e DQO.

As análises de carbono orgânico total (COT) foram realizada em um analisador TOC da marca Shimadzu modelo VCPH/CPN (Total Organic Carbon Analizer). As amostras do efluente foram homogeneizadas em um ultra som da marca Branson, por 3 minutos. Em seguida introduziu-se a amostra no analisador de carbono.

O princípio de funcionamento do equipamento baseia-se na combustão da

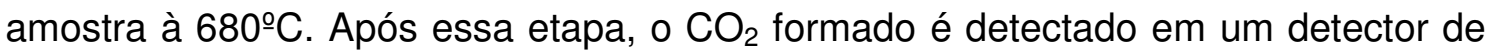
infravermelho. A quantificação foi realizada construindo uma curva de calibração com solução padrão de biftalato de potássio ( $\left.\mathrm{HOCOC}_{6} \mathrm{H} 4 \mathrm{COOK}\right)$.

Para o preparo da solução padrão pesaram-se $2,25 \mathrm{~g}$ de reagente p.a. biftalato de potássio, previamente seco entre 105 e $120^{\circ} \mathrm{C}$, por 2 horas e mantido em dessecador. Dissolveu-se essa massa em um béquer de $500 \mathrm{~mL}$ e transferiu-se para um balão de $1000 \mathrm{~mL}$ completando o volume com água deionizada. A concentração final foi de 1000mg/L de carbono (STANDARD METHODS 5210B, 1989).

\subsubsection{Determinação da DBO e da DQO \\ DBO}

A demanda bioquímica de oxigênio de uma água é a quantidade de oxigênio necessária para oxidar a matéria orgânica por decomposição microbiana aeróbia para uma forma inorgânica estável.

As análises de DBO são, geralmente, realizadas para avaliar a eficiência de estações de tratamento de efluentes, determinando a quantidade de oxigênio 
consumido pelos microorganismos durante a decomposição da matéria orgânica do efluente antes e após o seu tratamento. O princípio da DBO está no conceito de que a maioria dos compostos orgânicos presentes nos efluentes industriais são instáveis e podem ser biologicamente oxidados por bactérias aeróbias. Como produto da oxidação, têm-se compostos mais estáveis como $\mathrm{NO}_{3}^{-}, \mathrm{CO}_{2}$ entre outros (CRESPILHO, 2004).

Convencionou-se o termo $\mathrm{DBO}_{5,20}$ como a quantidade de oxigênio consumido durante um período de 5 dias numa temperatura de incubação de $20^{\circ} \mathrm{C}$. O resultado é obtido em miligrama de oxigênio consumido por litro de água $\left(\mathrm{mgL}^{-1}\right)$ (CETESB,2006).

Para a determinação da $\mathrm{DBO}_{5,20}$ no efluente em estudo utilizou-se o equipamento $\mathrm{HACH}$, modelo DBOTrak. Esse equipamento é composto por seis garrafas âmbar com capacidade para $500 \mathrm{~mL}$ de solução cada uma.

Adicionaram-se nas garrafas $95 \mathrm{~mL}$ da amostra do efluente antes e após o tratamento por EF e anotou-se o valor da DBO após cinco dias. A temperatura foi mantida em $20^{\circ} \mathrm{C}$ por uma câmara de germinação climatizada Tecnal, modelo TE 401.

O método utilizado por esse aparelho baseia-se na diferença de pressão de oxigênio. Os seis frascos são conectados nas mangueiras, que vão aos sensores de pressão pneumática internos. As bactérias contidas nas amostras utilizam o oxigênio para oxidar a matéria orgânica, consumindo assim o oxigênio dissolvido das amostras. O oxigênio consumido é reposto a partir do ar existente no frasco de amostra hermeticamente fechado, resultando na queda da pressão interna do frasco. As modificações da pressão são convertidas diretamente em DBO por mg/L. Durante cinco dias as amostras foram agitadas por barras magnéticas. $O$ dióxido de 
carbono gerado pela oxidação da matéria orgânica é eliminado dos frascos de amostras por cristais de hidróxido de lítio que estão alojados dentro dos tubos conectados na tampa. Para que a atividade microbiana não seja interrompida por falta de nutriente, adiciona-se o mesmo (semente) no inicio do experimento. $O$ equipamento DBOTrak possui capacidade de determinar $\mathrm{DBO}_{5,20}$ até $700 \mathrm{mgL}^{-1}$, para amostras que ficaram acima desse valor, realizou-se a diluição das mesmas, considerando o fator de diluição nos cálculos finais .

\section{DQO}

A demanda química de oxigênio é indicador de matéria orgânica baseado na concentração de oxigênio consumido para oxidar a matéria orgânica, biodegradável ou não, em meio ácido e condições energéticas por ação de um agente químico oxidante forte. Esta técnica apenas estima a concentração de matéria orgânica em termos de oxigênio consumido já que nos corpos d'águas as condições não são tão energéticas, além do fato de que algumas espécies inorgânicas, tais como nitritos, compostos reduzidos de enxofre e substâncias orgânicas - como hidrocarbonetos aromáticos, compostos alifáticos de cadeia aberta e piridinas - não são oxidadas. A principal vantagem da DQO é a rapidez, pouco mais de duas horas, enquanto que a DBO leva 5 dias.

Como na $\mathrm{DBO}_{5,20}$ mede-se apenas a fração biodegradável, quanto mais este valor se aproximar da DQO significa que mais facilmente biodegradável será o efluente (CETESB,2008).

Para determinação da DQO, o método de refluxo do dicromato, trata-se de uma reação de oxidação da matéria orgânica e inorgânica da amostra por uma quantidade conhecida de dicromato de potássio em meio fortemente ácido e elevada 
temperatura na presença de um catalisador (o sulfato de prata) e sulfato de mercúrio como inibidor de cloretos. É usado o dicromato de potássio (cromo na forma de $\mathrm{Cr}^{6+}$ ) devido a sua forte capacidade oxidante, facilidade de manipulação e aplicabilidade, além de ser um padrão primário. A utilização de um catalisador, como o sulfato de prata, é necessária para tornar possível a oxidação de compostos alifáticos de cadeia reta.

Após a oxidação da matéria orgânica presente, o excesso de dicromato é titulado com sulfato ferroso amoniacal. A quantidade de matéria orgânica oxidada é medida como equivalente de oxigênio, proporcional a quantidade de dicromato de potássio consumida (MOORE; KRONER; RUCHHOFT, 1949).

As reações envolvidas são:

Oxidação da matéria orgânica:

$$
\begin{array}{cr}
3 \mathrm{CH}_{2} \mathrm{O}+2 \mathrm{Cr}_{2} \mathrm{O}_{7}^{2-}+16 \mathrm{H}^{+} & \rightarrow 3 \mathrm{CO}_{2}+11 \mathrm{H}_{2} \mathrm{O}+4 \mathrm{Cr}^{3+} \\
\text { alaranjado } & \text { azul-esverdeado }
\end{array}
$$

Titulação do excesso de dicromato:

$$
\begin{array}{lr}
\mathrm{Cr}_{2} \mathrm{O}_{7}^{2-}+6 \mathrm{Fe}^{2+}+14 \mathrm{H}^{+} \rightarrow 2 \mathrm{Cr}^{3+}+6 \mathrm{Fe}^{3+} 7 \mathrm{H}_{2} \mathrm{O} \\
\text { azul-esverdeado } & \text { marrom-avermelhado }
\end{array}
$$

A DQO foi realizada utilizando-se o método titulométrico, inicialmente em um balão de fundo chato adiciona-se $20 \mathrm{~mL}$ da amostra, ou uma porção diluída a $20 \mathrm{~mL}$, aproximadamente $0,4 \mathrm{~g}$ de sulfato de mercúrio e $10 \mathrm{~mL}$ de solução de dicromato de potássio (dissolveu-se 12,259 g de dicromato de potássio em 1 litro de água destilada). Cuidadosamente, acrescentou-se $30 \mathrm{~mL}$ de ácido sulfúrico-sulfato de prata (10,13 g de sulfato de prata em 1 litro de ácido sulfúrico concentrado), sempre 
agitando o balão. Fez-se um branco, utilizando ao invés da amostra, $20 \mathrm{~mL}$ de água destilada. Os balões seguiram para chapas aquecedoras, conectando-os aos condensadores. A solução ficou em refluxo por 2 horas a partir do início da fervura. Depois de completada as 2 horas, e com o SFA (dissolveu-se $98 \mathrm{~g}$ de sulfato ferroso amoniacal (SFA), $20 \mathrm{~mL}$ de ácido sulfúrico concentrado, deixar esfriar e completar o volume para 1 litro) já padronizado, realiza-se a titulação da amostra e do branco usando ferroína como indicador. O ponto final é a mudança de cor de azulesverdeado para marrom-avermelhado (ASTM,1995).

\subsubsection{Determinação da Condutividade}

A condutividade é a expressão numérica da capacidade que uma determinada amostra de água tem de conduzir a corrente elétrica. A condutividade depende das concentrações iônicas e da temperatura, e indica a quantidade de sais existentes na água, representando uma medida indireta da concentração de poluentes. Em geral, níveis superiores a $100 \mu \mathrm{Scm}^{-1}$ em águas doces indicam ambientes impactados (CETESB, 2006).

As medidas de condutividade foram realizadas em leitura direta por condutivímetro DM31-Digimed.

As leituras de condutividade foram realizadas com relação à condutividade da solução padrão de cloreto de potássio $0,0100 \mathrm{molL}^{-1}$. Esta solução tem condutância de $1414 \mu \mathrm{Scm}^{-1}$ a $25^{\circ} \mathrm{C}$.

\subsubsection{Determinação da Turbidez}

A turbidez é a medida da dificuldade de um feixe de luz atravessar uma certa quantidade de água. Essa medição é feita com o turbidímetro ou nefelômetro, que 
compara o espalhamento de um feixe de luz ao passar pela amostra, com o de um feixe de igual intensidade, ao passar por uma suspensão padrão. Quanto maior o espalhamento, maior será a turbidez.

As principais causas da turbidez da água são: presença de matérias sólidas em suspensão (silte, argila, sílica, colóides), matéria orgânica e inorgânica finamente divididas, organismos microscópicos e algas. A origem desses materiais pode ser o solo (quando não há mata ciliar); a mineração (como a retirada de areia ou a exploração de argila); as indústrias; ou o esgoto doméstico, lançado no manancial sem tratamento (BERNARDO, 1993; CLESCERI; GREENBERG; EATON,1998).

A determinação da turbidez é uma maneira rápida de avaliar o quanto a água está imprópria ou própria para o abastecimento. A água turva causa problemas estéticos, de filtrabilidade e de desinfecção. Em se tratando de água potável é recomendável que a turbidez não ultrapasse 10NTU (unidades de turbidez nefelométricas).

Antes de se determinar a turbidez, a amostra foi conservada por 24 horas a $4^{\circ} \mathrm{C}$. O intervalo de medida varia de 0,05 a 40NTU, sendo a amostra passível de diluição caso não se enquadre nesse intervalo.

A turbidez das amostras foi determinada pelo método nefelométrico em um turbidímetro da marca Micronal modelo B250 (CLESCERI;GREENBERG;EATON, 1998).

O método baseia-se na leitura da intensidade da luz dispersa pela amostra em ângulo de $90^{\circ}$ em relação à luz incidente, relacionando com à intensidade da luz dispersa por uma suspensão-padrão nas mesmas condições. A suspensão-padrão de referência é de formazina. 
Desse modo, padronizou-se:

$1 \mathrm{NTU}=7,5 \mathrm{mg} / \mathrm{L}$ de $\mathrm{SiO}_{2}$

$1 \mathrm{NTU}=1,0 \mathrm{mg} / \mathrm{L}$ de formazina padrão

\subsubsection{Determinação de Nitrogênio Kjeldahl Total e Nitritos}

Os elementos nitrogênio e fósforo, essenciais para o crescimento dos microorganismos, plantas e animais, são conhecidos como nutrientes ou bioestimulantes. A presença de traços de outros elementos, tal como o ferro, são também necessários para o crescimento biológico, mas nitrogênio e fósforo são, na maioria dos casos, os principais nutrientes de importância. Uma vez que o nitrogênio é um elemento construtivo essencial na síntese da proteína, os dados de nitrogênio serão necessários para avaliar a tratabilidade do efluente por processos biológicos. Nitrogênio insuficiente pode necessitar de adição de nitrogênio para tornar o efluente tratável. Os requisitos de nutrientes para o tratamento biológico de efluentes devem ser avaliados onde o controle do crescimento algal nos corpos receptores do efluente tratado é necessário, desta maneira, a remoção ou redução de nitrogênio em efluentes antes do despejo em corpo receptor faz-se necessária.

O nitrogênio orgânico e a amônia podem ser determinados juntos e são referidos como "Nitrogênio Kjeldahl", o termo que reflete a técnica usada para suas determinações. Nitrogênio orgânico inclui matéria natural (proteínas, peptídios, ácidos nucléicos, uréia) e numerosos compostos orgânicos sintéticos. A amônia está naturalmente presente em águas superficiais e águas residuárias. Ela é produzida largamente pela amonificação de nitrogênio orgânico e pela hidrólise da uréia. Em algumas estações de tratamento de água, a amônia é acrescentada para reagir com 
o cloro formando cloro residual combinado, as cloraminas (YASUHARA; NOKIHARA, 2001)

Para determinar nitrogênio no presente trabalho as amostras foram digeridas em um Digesdahl, da marca Hach modelo Odissey DR 240. Uma alíquota de 10mL do resíduo foi digerido com $10 \mathrm{~mL}$ de ácido sulfúrico concentrado, com adição de peróxido de hidrogênio até a solução permanecer incolor.

O nitrogênio da amostra é convertido em sulfato de amônio, sem prévia remoção da amônia, por digestão com ácido sulfúrico (EPA, 2005; LABCONCQ, 2006)

A determinação de nitrogênio total foi feita em um espectrofotômetro da marca Hach, modelo Odissey DR 240 com faixa de concentração detectável de 1 a 150mg/L em comprimento de onda de 660nm (EPA, 1989).

Após a leitura realizou-se o cálculo em ppm de acordo com a Eq (11)

Ppm de $\mathrm{TKN}=75 \times \mathrm{A} / \mathrm{BxC}$, onde:

$A=$ leitura no display $\mathrm{mgL}^{-1}$

$\mathrm{B}=$ volume da amostra para digestão $(\mathrm{mL})$

$\mathrm{C}=$ volume da amostra digerida $(\mathrm{mL})$

\section{Nitritos}

O Nitrito, um estado intermediário do ciclo do nitrogênio, é formado durante a decomposição da matéria orgânica e prontamente oxidada a nitrato. Esses processos ocorrem em instalações de tratamento de água, sistemas de distribuição de água e águas naturais. Em águas superficiais a presença de nitritos pode indicar a decomposição parcial de matéria orgânica, descarga excessiva oriunda de estação de tratamento de água ou poluição industrial. Em águas poluídas a presença de nitrito pode indicar a presença de bactérias redutoras de nitrato quando as 
condições presentes são anaeróbias. Concentrações até $0,1 \mathrm{mg} / \mathrm{l}$ são inofensivas, já em concentrações entre 0,1 e 0,5 podem provocar danos a certas espécies de peixes. Existe perigo elevado em caso de concentrações superiores a $1 \mathrm{mg} / \mathrm{L}$, pior ainda, se combinado com teores baixos de cloretos e de oxigênio dissolvido, podendo causar metahemoglobinemia (o ferro na hemoglobina se torna incapaz de transportar oxigênio), também conhecida como doença do sangue marrom (BOLTZ,1958).

A determinação de nitrito foi realizada devido o resíduo em estudo apresentar nitratos como agente anti-corrosivo.

A determinação de nitritos foi baseada na formação de uma coloração rosa púrpura produzida pela reação do nitrito com 0 dihidrocloreto $\mathrm{N}$-(1-naftil)etilenediamina (NED) em pH 2,0. Este método é aplicável para medidas espectrofotométrica em concentrações na faixa de 10 a $1000 \mu \mathrm{g}$ de $\mathrm{NO}_{2^{-}}$. O desenvolvimento da coloração do complexo formado obedece a Lei de Beer até 180 $\mu \mathrm{g} \mathrm{N} \mathrm{L} \mathrm{N}^{-1}$ (STANDARD METHODS, 4500B).

O experimento foi realizado no espectrofotômetro da marca Hach, modelo ODISSEY DR240 com comprimento de onda de 543nm e caminho ótico de $1 \mathrm{~cm}$.

O valor encontrado é determinado diretamente no aparelho.

\subsubsection{Fósforo total}

Fósforo é encontrado em águas naturais, efluentes domésticos e industriais quase exclusivamente na forma de fosfatos. Estes são classificados como ortofosfatos, fosfatos condensados (piro-, meta- e outros polifosfatos) e fosfatos orgânicos. As formas podem estar solubilizadas, em partículas, ou em corpos de organismos aquáticos. 
Fósforo na água apresenta-se principalmente na forma de ortofosfatos, que estão diretamente disponíveis para o metabolismo biológico sem necessidade de conversões a formas mais simples. Dentre os principais ortofosfatos tem-se: $\mathrm{PO}_{4}{ }^{2-}$, $\mathrm{HPO}_{4}{ }^{2-}, \mathrm{H}_{2} \mathrm{PO}_{4}^{-}$e $\mathrm{H}_{3} \mathrm{PO}_{4}$.

Os polifosfatos são moléculas mais complexas, com dois ou mais átomos de fósforo. Os polifosfatos se transformam em ortofosfatos pelo mecanismo de hidrólise, mas tal transformação é usualmente lenta. Os polifosfatos estão sempre presentes em despejos contendo detergentes sintéticos.

O fósforo orgânico é normalmente encontrado em águas residuárias industriais e lodos provenientes do tratamento de resíduos

O fósforo é essencial ao crescimento dos organismos das águas superficiais, como, por exemplo, os microrganismos do plâncton, especialmente algas. Ele pode ser o nutriente que limita a produtividade destas águas e, neste caso, o lançamento de despejos tratados ou não, ou o carreamento de fertilizantes para as águas superficiais, pode estimular o desenvolvimento excessivo desses organismos (CETESB, 2006).

Para a determinação de fósforo orgânico as amostras foram digeridas em meio ácido de acordo com o método para determinação de nitrogênio Kjedahl.

Após digerida, completou-se com balão de $100 \mathrm{~mL}$ com água deionizada. A partir de $30 \mathrm{~mL}$ dessa solução adicionou-se $10 \mathrm{~mL}$ de uma solução de vanadato mobilidato e completou para $50 \mathrm{~mL}$. Uma solução branco foi preparada nas mesmas condições.

O princípio do método baseia-se na solução diluída de ortofosfato reagindo com molibdato de amônia em condições ácidas, formando o ácido molibdíco fosfórico que, na presença de vanádio, desenvolve uma coloração amarela pela 
formação do complexo ácido vanadomolibdofosfórico. A intensidade da cor é proporcional a concentração de fosfato (KITSON; MELLON,1944; PROFT,1964).

O experimento foi realizado no espectrofotômetro da marca Hach, modelo ODISSEY DR240 em comprimento de onda de 400nm com faixa de concentração detectável de 1,0 a $5,0 \mathrm{mgL}^{-1}$.

O valor encontrado no aparelho é aplicado na Eq 12 para determinar a concentração de fósforo presente no efluente.

$\mathrm{mgP} / \mathrm{L}=\mathrm{mg} \mathrm{P}(\mathrm{em} 50 \mathrm{~mL}$ no volume final) $100 / \mathrm{mL}$ da amostra

\subsubsection{Métodos Cromatográficos (BTEX, HPAs e Nitrosaminas)}

\section{BTEX}

A presença de BTEX está relacionada ao fato de o fluido de corte apresentar grande quantidade de óleos e graxas.

Contaminação por benzeno, etilbenzeno, tolueno e isômeros de xileno (BTEX), estão associados a produtos derivados do petróleo, como por exemplo, a gasolina que apresenta cerca de 10 a 59\% de compostos aromáticos. Os maiores problemas das contaminações por derivados de petróleo são atribuídos aos hidrocarbonetos monoaromáticos (BTEX), estes compostos são poderosos depressores do sistema nervoso central, e apresentam toxicidade crônica, mesmo em pequenas concentrações (da ordem de ppb), sendo o benzeno o mais tóxico e comprovadamente carcinogênico (MELEQUIADES et al., 2006).

Para a extração dos BTEX nas amostras foi utilizada a técnica headspace no modo estático. As extrações dos compostos foram realizadas em triplicata e feitas três leituras cromatográficas. Utilizaram-se vials de $27 \mathrm{~mL}$, aos quais foram 
adicionadas $10,00 \mathrm{~mL}$ da amostra. Em seguida os vials foram transportados para a encubadora do headspace onde foram aquecidos a uma temperatura constante de $80^{\circ} \mathrm{C}$, por 15 minutos, para promover a volatilização dos analitos. Um volume de $800 \mu \mathrm{L}$ dos analitos foi extraído do vial por uma seringa aquecida, especial para gases, e transportado para o injetor do cromatógrafo e, assim, separado na coluna cromatográfica e quantificado.

A coluna utilizada para a separação dos analitos é a HP1 (30m X 0,25mm). O gás de arraste utilizado é o nitrogênio com um de fluxo de $1,0 \mathrm{~mL} \mathrm{~min}^{-1}$. A rampa de aquecimento utilizada é: $40^{\circ} \mathrm{C}, 5^{\circ} \mathrm{C} \cdot \mathrm{min}^{-1}$ até $60^{\circ} \mathrm{C}$, e $10^{\circ} \mathrm{C} \cdot \mathrm{min}^{-1}$ até $120^{\circ} \mathrm{C}$, totalizando um tempo de análise de 11 minutos. A temperatura utilizada para o injetor é de $220^{\circ} \mathrm{C}$ e para o detector $280^{\circ} \mathrm{C}$. O modo de injeção utilizado é split 1:10.

O aparelho utilizado para as análises foi um cromatógrafo a gás da marca Shimadzu modelo GC-17A, utilizando um detector de ionização de chama (FID).

Na Tabela 4 encontram-se os tempos de retenção de uma mistura de BTEX nas condições mencionadas acima.

Tabela 4: Tempo de retenção obtido para uma mistura de BTEX padrão, utilizandose um cromatógrafo a gás com detector de ionização de chama

\begin{tabular}{cc}
\hline Composto & Tempo de Retenção (min.) \\
\hline Benzeno & 1,52 \\
Tolueno & 2,36 \\
Etilbenzeno & 3,72 \\
Xileno(m,p) & 3,83 \\
Xileno (o) & 4,32 \\
\hline
\end{tabular}




\section{HPAs}

Os hidrocarbonetos policíclicos aromáticos (HPAs) são compostos que possuem dois ou mais anéis aromáticos condensados em sua estrutura, eles representam uma importante classe de carcinógenos químicos formados durante a combustão incompleta de material orgânico (NETO et al., 2000)

Os HPAs podem ser introduzidos no ambiente a partir de numerosas fontes: os motores de exaustão a gasolina e especialmente os de combustão a diesel, o "alcatrão" da fumaça do cigarro, a superfície dos alimentos chamuscados ou queimados, fumaça da queima de madeira ou carvão, e outros processos de combustão parcial, nos quais o carbono ou combustível não são convertidos em CO ou $\mathrm{CO}_{2}$ (NETO et al., 2000).

Os 16 HPAs considerados como prioritários, da perspectiva dos efeitos adversos à saúde humana, pela Agência de Proteção Ambiental dos Estados Unidos (USEPA, 2001), por serem os mais tóxicos e exibirem maior possibilidade de exposição à população humana são: acenaftileno, acenafteno, antraceno, fluoreno, fluoranteno, naftaleno, pireno, fenantreno e benzo(g,h,i)perileno (não classificados pela USEPA como cancerígenos humanos); e benzo(a)antraceno, benzo(a)pireno, benzo(b)fluoranteno, benzo(k)fluoranteno, dibenzo(a,h)antraceno, Indeno(1,2,3-cd), criseno e pireno (classificados como prováveis cancerígenos humanos) (CASTRO et al., 2000).

Para a determinação de HPAs transfere-se uma amostra de $100 \mathrm{~mL}$ para um funil de separação, adicionam-se $10,00 \mathrm{~mL}$ de uma mistura de solventes hexano/acetona $80 / 20 \mathrm{v} / \mathrm{v}$. A amostra é agitada vigorosamente e deixada em repouso até a completa separação das fases. A fase orgânica é armazenada e uma alíquota de $2 \mu \mathrm{L}$ é injetada no cromatógrafo. 
A coluna utilizada para a separação dos analitos é a HP1 (30m X 0,25mm). Nitrogênio é usado como gás de arraste com uma razão de fluxo de $1,0 \mathrm{~mL} \mathrm{~min}{ }^{-1}$. A rampa de aquecimento utilizada é: $35^{\circ} \mathrm{C}$, e $10^{\circ} \mathrm{C} \cdot \mathrm{min}^{-1}$ até $265^{\circ} \mathrm{C}$ onde permanece por 12 minutos, totalizando um tempo de análise de 35 minutos. A temperatura utilizada para o injetor é de $220^{\circ} \mathrm{C}$ e para o detector $280^{\circ} \mathrm{C}$. O modo de injeção utilizado é split 1:10.

O aparelho utilizado para as análises foi um cromatografo gasoso da marca Shimadzu modelo GC-17A, utilizando um detector FID.

Na Tabela 5 encontram-se os tempos de retenção de uma mistura de HPAs obtido no aparelho e condições mencionadas acima.

Tabela 5: Tempo de retenção obtido para uma mistura de HPAs padrão, utilizandose um cromatógrafo a gás com detector de ionização de chama

\begin{tabular}{cc}
\hline Composto & Tempo de Retenção (min) \\
\hline Naftaleno & 4,15 \\
Acenaftaleno & 6,30 \\
Acenafteno & 6,72 \\
Fluoreno & 7,96 \\
Fenantreno & 10,30 \\
Antraceno & 10,41 \\
Fluoranteno & 13,33 \\
Pireno & 13,78 \\
Criseno & 17,08 \\
Benzo (k) & 19,49 \\
Benzo (a) & 20,22 \\
Indeno & 22,67 \\
Benzo $(\mathrm{g}, \mathrm{h}, \mathrm{i})$ & 23,25 \\
\hline
\end{tabular}

\section{NITROSAMINAS}

O termo nitrosaminas reúne uma grande variedade de tipos estruturais de compostos de diferentes massas moleculares, que surgem como produtos da reação de aminas ou aminoderivados com agentes nitrosantes. A característica estrutural 
comum é a presença do grupo funcional N-NO, incluindo nitrosaminas e nitrosamidas. Essa classe de compostos, muitos dos quais carcinogênicos, foi estudada em vários materiais, como gêneros alimentícios, produtos farmacêuticos, amostras ambientais (água, solo, ar etc.), pesticidas, herbicidas, borracha, cosméticos etc. Em função do potencial mutagênico e carcinogênico destes compostos em animais, estima-se que o nível de exposição tolerável pelo homem para as nitrosaminas mais voláteis encontra-se na faixa de 5 a $10 \mu \mathrm{g} \cdot \mathrm{kg}^{-1}$, por esta razão o limite de detecção mínimo de $10 \mu \mathrm{g} \cdot \mathrm{kg}^{-1}$ é geralmente aceito (FILHO, et al., 2003).

Neste trabalho foi realizada a determinação de nitrosaminas devido à possível formação através da reação de nitritos e aminas secundárias presentes no fluido de corte.

Para a determinação de nitrosaminas utilizam-se vials com volume conhecido, aos quais são adicionadas $10 \mathrm{~mL}$ da amostra, em seguida os vials são transportados para a incubadora do Headspace onde são aquecidos a uma temperatura constante de $80^{\circ} \mathrm{C}$ para promover a volatilização dos analitos. Os analitos são extraídos do vial por uma seringa aquecida, especial para headspace, e transportados para o injetor do cromatógrafo e, assim, separados e quantificados na coluna cromatográfica.

A coluna utilizada para a separação dos analitos é a HP5 (30m X 0,25mm). Hêlio é usado como gás de arraste com uma razão de fluxo de 1,0 mL min-1. A rampa de aquecimento utilizada é: $40^{\circ} \mathrm{C}$, e $10^{\circ} \mathrm{C} \cdot \mathrm{min}^{-1}$ até $250^{\circ} \mathrm{C}$ onde permanece por 4 minutos, totalizando um tempo de análise de 25 minutos. A temperatura utilizada para o injetor é de $250^{\circ} \mathrm{C}$, temperatura da linha de transferência $180^{\circ} \mathrm{C}$ e para o detector de massas temperatura de $260^{\circ} \mathrm{C}$. O modo de injeção utilizado é split $1: 10$ 
O aparelho utilizado para as análises foi um cromatógrafo gasoso da marca Shimadzu, modelo GCMS-QP2010 Plus, utilizando um detector de massas. 
RESULTADOSE DISCUSSÃO 


\section{Resultados e Discussão:}

\subsection{Caracterização do resíduo após o processo de usinagem}

Na Tabela 6, apresentam-se os parâmetros para o descarte de efluentes estipulados pela Legislação estadual (Decreto ํㅜ 8.468, de 8 de setembro de 1976, artigo 19A) e os valores encontrados para o fluido de corte antes e após ser utilizado no processo de usinagem.

Tabela 6. Parâmetros de qualidade do fluido de corte e os valores permitidos para descarte.

\begin{tabular}{|c|c|c|c|}
\hline Parâmetros & $\begin{array}{c}\text { Antes do } \\
\text { processo de } \\
\text { usinagem }\end{array}$ & $\begin{array}{c}\text { Após o processo } \\
\text { de usinagem }\end{array}$ & $\begin{array}{c}\text { Valores para } \\
\text { descarte } \\
\text { (Decreto n8.468) }\end{array}$ \\
\hline $\mathrm{pH}$ & $6,00 \pm 0,05$ & $5,84 \pm 0,05$ & 6,0 a 10,0 \\
\hline Temperatura $\left({ }^{\circ} \mathrm{C}\right)$ & $25,0 \pm 0,5$ & $25,0 \pm 0,5$ & \\
\hline Condutividade $\mu \mathrm{S} / \mathrm{cm}$ & - & $1775,0 \pm 0,5$ & $(-)$ \\
\hline Sólidos totais $(\mathrm{mg} / \mathrm{L})$ & $82460,0 \pm 0,5$ & $11700,0 \pm 0,5$ & $(-)$ \\
\hline $\begin{array}{l}\text { Carbono orgânico } \\
\text { total(mg/L) }\end{array}$ & $185300,0 \pm 0,1$ & $11435,0 \pm 0,4$ & $(-)$ \\
\hline $\mathrm{DBO}_{5}(\mathrm{mg} / \mathrm{L})$ & $20000,0 \pm 0,01$ & $5000,0 \pm 0,1$ & $60^{\mathrm{a}}$ \\
\hline DQO (mg/L) & $82128,0 \pm 0,05$ & $17000,0 \pm 0,2$ & $(-)$ \\
\hline Óleos e graxas (mg/L) & $16532,0 \pm 0,5$ & $9942,0 \pm 0,2$ & 150 \\
\hline Turbidez (NTU) & - & $26300,0 \pm 0,3$ & $(-)$ \\
\hline Nitrogênio Kjedahl (mg/L) & $675,0 \pm 0,5$ & $165,0 \pm 0,5$ & $(-)$ \\
\hline Nitrito (mg/L) & - & $295,0 \pm 0,4$ & $(-)$ \\
\hline Fósforo total (mg/L) & $52600,0 \pm 0,5$ & $9667,0 \pm 0,6$ & $(-)$ \\
\hline $\mathrm{Fe}(\mathrm{mg} / \mathrm{L})$ & $0,680 \pm 0,001$ & $31,3 \pm 0,08$ & 15,0 \\
\hline $\mathrm{Al}(\mathrm{mg} / \mathrm{L})$ & nd & $5,48 \pm 0,05$ & $(-)$ \\
\hline $\mathrm{Cr}(\mathrm{mg} / \mathrm{L})$ & nd & $0,242 \pm 0,06$ & 1,5 \\
\hline $\mathrm{Cu}(\mathrm{mg} / \mathrm{L})$ & nd & $1,75 \pm 0,04$ & 1,5 \\
\hline $\mathrm{Mn}(\mathrm{mg} / \mathrm{L})$ & nd & $0,085 \pm 0,02$ & $(-)$ \\
\hline $\mathrm{Ni}(\mathrm{mg} / \mathrm{L})$ & nd & $0,219 \pm 0,06$ & 2,0 \\
\hline $\mathrm{Pb}(\mathrm{mg} / \mathrm{L})$ & nd & $0,105 \pm 0,01$ & 1,5 \\
\hline $\mathrm{Zn}(\mathrm{mg} / \mathrm{L})$ & nd & $5,68 \pm 0,12$ & 5,0 \\
\hline
\end{tabular}

(-) : Valores não citados na lesgislação (Decreto $n^{0} 8.468$,artigo 19A)

a :Valores permitidos para descarte em águas ( Decreto noำ 8.468 ,artigo 18A)

Segundo o Decreto no 8.468 (artigo 19A) os efluentes de qualquer fonte poluidora somente poderão ser lançados em sistemas de esgotos, provido de 
tratamento com capacidade e tipo adequado, quando a critério da CETESB, tal tratamento atender às finalidades pretendidas.

De acordo com os dados em negrito da Tabela 6 os valores de óleos e graxas, ferro, cobre e zinco estão acima do estabelecido pela legislação. Assim, o fluido de corte após o processo de usinagem precisa de tratamento para o descarte em esgoto.

A legislação não faz referências a alguns parâmetros para o descarte, porém há no artigo 18 do mesmo decreto para o descarte em águas coletoras o valor máximo permitido da DBO. Valores elevados podem contaminar o corpo receptor. Como era de se esperar, a concentração de metais aumentou no fluido após a utilização do mesmo nos processos de usinagem, devido as reações redutoras que ocorrem com a peça ao ser usinada.

O fluido de corte sintético apresenta várias características bem definidas, como presença de compostos orgânicos e inibidores de corrosão e aditivos de lubrificação como: fosfatos, nitritos, aminas, germicidas e glicóis. Com os dados da Tabela 6, podemos verificar que os parâmetros diminuem de concentração, devido às altas temperaturas $\left(200^{-300^{\circ}} \mathrm{C}\right)$ em que o fluido de corte é submetido durante a usinagem, fazendo com que ocorram mudanças na estrutura química e consequentemente na sua composição.

A diminuição nos óleos e graxas está relacionada à diminuição na concentração do polímero. A análise de óleos e graxas não é seletiva, ou seja, o resultado depende da solubilidade dos componentes no solvente orgânico, por o fluido possuir características de lubrificação, ou seja, características parecidas com o óleo lubrificante, quanto menor a concentração de polímero menor a concentração de óleos e graxas. 
O processo industrial de usinagem gera uma grande contaminação, já que os fluidos geralmente são reutilizados acrescentando água, devido sua evaporação durante o processo de usinagem (altas temperatura), até que percam suas características de corte.

A qualidade da água usada para a preparação dos fluidos de corte solúveis nem sempre possui as condições ideais para este fim. A água pode estar contaminada e é muitas vezes de propriedade dura, classificação esta baseada na presença de cátions cálcio, magnésio e ferrosos. Esses, em quantidades elevadas, podem trazer muitos problemas, tais como: formar compostos insolúveis, reduzir a reserva de inibidores de corrosão e biocidas e formar depósitos pegajosos no sistema de circulação das máquinas-ferramentas, o que vêm obstruir a passagem dos fluidos e provocar um possível processo de instabilidade do mesmo (DICK; GREGORY,1997).

\subsection{Tratamento do fluido de corte utilizando a EF}

$\mathrm{Na}$ Tabela 7, apresenta-se as relações entre $\mathrm{o} \mathrm{pH}$ do fluido de corte tratado por EF em diversas correntes aplicadas com tempo de tratamento de 20 min cada.

Tabela7. Parâmetros do resíduo tratado por EF

\begin{tabular}{lcccc}
\hline Corrente $(A)$ & 0,75 & 0,80 & 0,85 & 1,00 \\
& & & & \\
\hline pH sem inversão da polaridade & $7,01 \pm 0,05$ & $7,10 \pm 0,04$ & $7,18 \pm 0,03$ & $7,24 \pm 0,04$ \\
pH com inversão de polaridade a & $7,16 \pm 0,03$ & $7,23 \pm 0,02$ & $7,25 \pm 0,04$ & $7,30 \pm 0,05$ \\
cada 5min de tratamento & & & & \\
\hline
\end{tabular}

$\mathrm{O}$ pH do resíduo antes do tratamento era de 5,84, como mostra a Tabela 7 foi observado após o tratamento um aumento do mesmo. Uma das características da EF é aumentar o valor do $\mathrm{pH}$ do resíduo, caso este seja ácido. Esse fato decorre 
porque a EF produz íons hidroxilas como mostra a página 21. Foi verificado por Chen et al, que caso o resíduo tenha um pH acima de $9,00 \circ \mathrm{pH}$ do resíduo tratado tende a diminuir. Pode-se dizer que a EF pode neutralizar o $\mathrm{pH}$ do meio.

O aumento do $\mathrm{pH}$ com a inversão da polaridade demonstra uma maior formação de hidroxilas.

Quando se aplica uma corrente elétrica entre os eletrodos há uma passivação dos cátodos devido principalmente à formação de óxidos de alumínio, além de gorduras que estão presentes no resíduo. Com isso há um decaimento do potencial aplicado, aumentando a resistividade à passagem de corrente, dificultando a geração do agente coagulante como mostra a Figura 9.

$\mathrm{Na}$ inversão de polaridade tem-se o objetivo de aumentar a vida útil do eletrodo e diminuir a resistividade do sistema fazendo com que o eletrodo que se comporta como cátodo por um tempo, passa a se comportar como ânodo após a inversão. Como o potencial não decai rapidamente invertendo a polaridade a cada 5 min, o eletrodo passa a liberar mais alumínio na solução para formação do agente coagulante, podendo assim ter uma maior eficiência da remoção dos contaminantes.

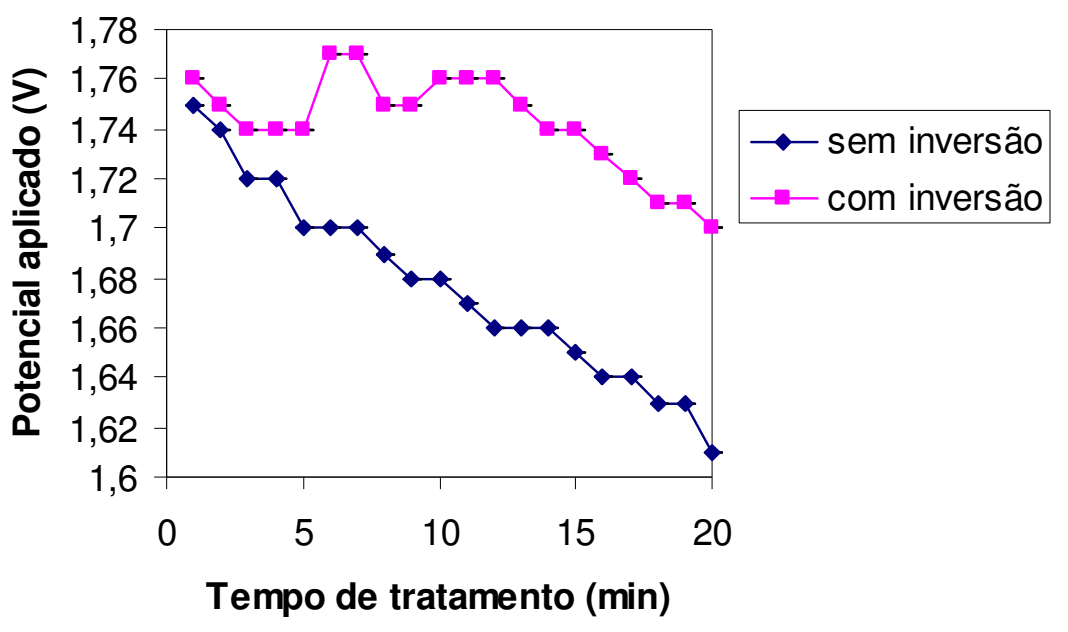

Figura 9: Decaimento do potencial em função do tempo de tratamento com a EF. 
Foi observada uma diminuição de sólidos totais dissolvidos no fluido de corte tratado em diversas correntes elétricas com tempo de tratamento de 20 min como mostra a Figura 10. A inversão da polaridade a cada 5 minutos de tratamento não demonstrou ter influenciado significativamente na remoção dos sólidos totais, por isso não foi utilizada a inversão da polaridade no tratamento do resíduo em estudo.

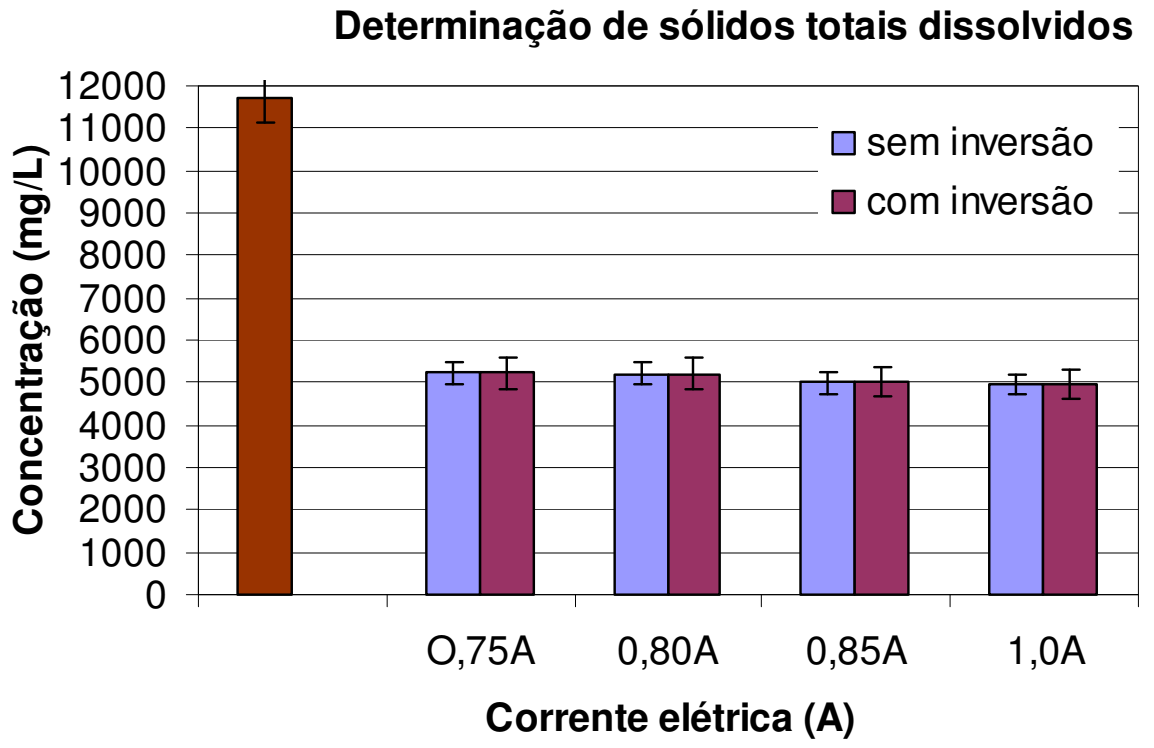

Figura 10: Determinação de sólidos totais em diversas correntes aplicadas.

A cor do fluido de corte não tratado (BRUTO) de origem leitosa foi bem clarificada após o tratamento deixando a solução mais cristalina. A Figura 11 demonstra que a coloração do efluente tratado não apresenta uma diferença visual utilizando uma corrente de 0,75 e 1,00A para o tratamento com inversão de polaridade. 

A)
B)
C)

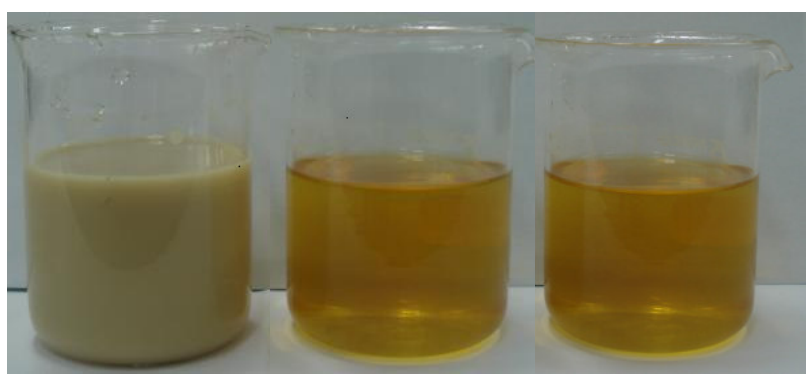

Figura 11: Fotografias dos resíduos

A ) fluido de corte não tratado (BRUTO); B) fluido de corte tratado com 0,75A;

C) fluido de corte tratado com 1,00A

\subsubsection{Parâmetros da EF}

A formação do lodo na parte superior do reator durante todo o tratamento com EF pode ser visualizada na Figura 12 utilizando uma corrente de 0,75A.

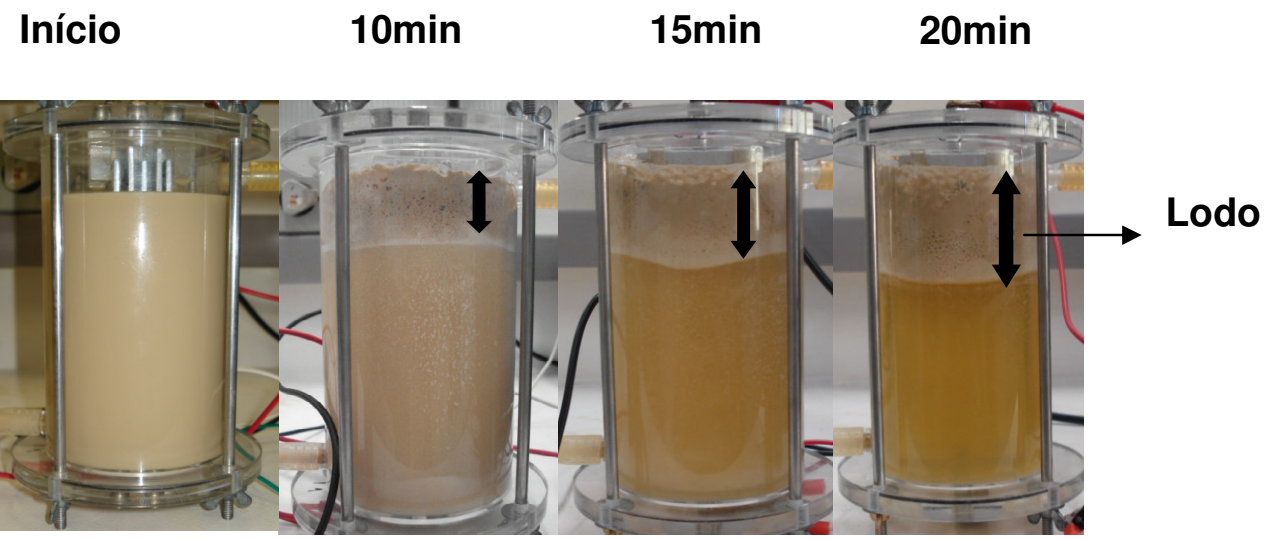

Figura 12: Fotografias durante o processo de tratamento do fluido de corte por EF com 0,75A.

Para escolher a melhor corrente a ser aplicada deve-se levar em consideração o menor volume de lodo gerado e a boa remoção de poluentes em menor tempo possível. 
A Tabela 8 mostra que o aumento da corrente aplicada diminui o tempo de tratamento e o teor de sólidos totais dissolvidos no fluido de corte tratado, porém aumenta a quantidade de lodo gerado.

Tabela 8. Parâmetros de tratamento sem inversão da polaridade

\begin{tabular}{cccc}
\hline $\begin{array}{c}\text { Corrente } \\
\text { aplicada (A) }\end{array}$ & $\begin{array}{c}\text { Tempo de } \\
\text { tratamento }(\boldsymbol{m i n})\end{array}$ & $\begin{array}{c}\text { Lodo } \\
\text { gerado } \\
(\boldsymbol{m L})\end{array}$ & $\begin{array}{c}\text { Sólidos totais dissolvidos no } \\
\text { resíduo tratado }(\mathbf{m g} / \mathbf{L})\end{array}$ \\
\hline 0,75 & $19,69 \pm 1,53$ & $62,00 \pm 2,00$ & $5224,67 \pm 0,57$ \\
0,80 & $19,67 \pm 1,53$ & $70,67 \pm 3,05$ & $5212,33 \pm 2,52$ \\
0,85 & $18,67 \pm 0,57$ & $73,00 \pm 3,00$ & $4994,67 \pm 1,30$ \\
1,00 & $14,67 \pm 0,57$ & $82,67 \pm 0,57$ & $4951,67 \pm 2,08$ \\
\hline
\end{tabular}

Foi utilizada durante o tratamento do resíduo em estudo uma corrente de 0,75A sem inversão da polaridade, onde houve um volume menor de lodo gerado e um teor de sólidos totais não tanto maior quando se aplica uma corrente de 1,00A como esta representada na Tabela 8.

A Tabela 9 apresenta alguns parâmetros calculados após o processo de EF para o tratamento do fluido de corte em estudo.

Os valores foram calculados pelas equações já descritas anteriormente. Calculado a potencia gasta do reator, pode-se estimar o custo de energia elétrica gasta no estado de São Paulo. 
Tabela 9. Parâmetros calculados após o tratamento com a Eletroflotação para uma corrente de 0,75 A

Parâmetros

Sem inversão de polaridade

* Valor estabelecido pela Companhia Paulista de Força e Luz em 2008

** Valor calculado pela Eq (7)

${ }^{* * *}$ Valor calculado pela Eq (6)

Podemos verificar na tabela em vermelho, que o custo aproximado para o tratamento de $550 \mathrm{~mL}$ de fluido de corte laboratório é baixo.

\subsection{Determinação de metais}

A determinação de metais foi realizada por ICP-AES. As curvas analíticas construídas para cada metal em diversas concentrações distintas estão representadas na Figura 13. 


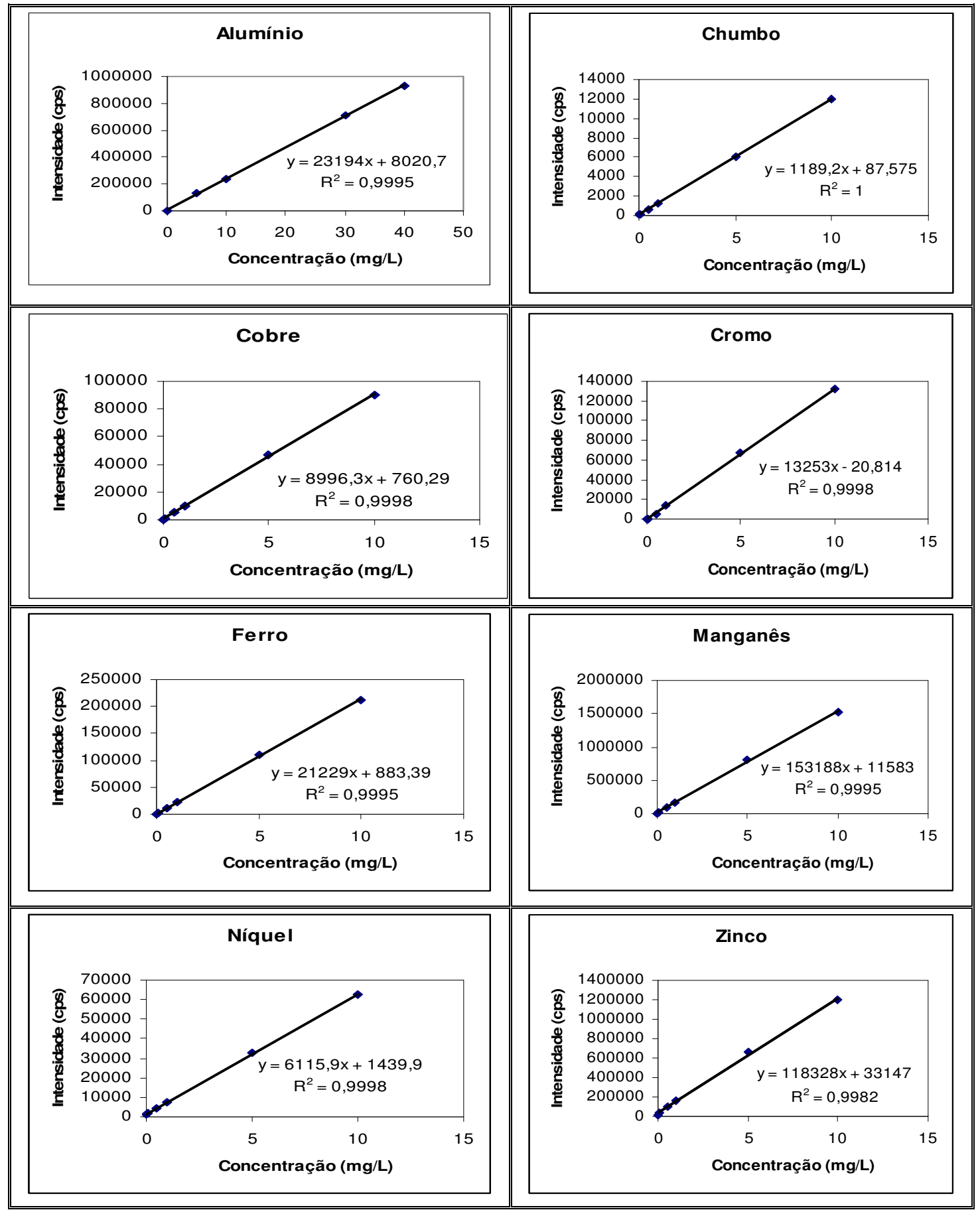

Figura 13: Curvas Analíticas para determinação de metais por ICP-AES. 
Na Tabela 10 estão representados os valores de LOQ e LOD para cada metal analisado de acordo com os valores permitidos segundo a legislação utilizada nesse estudo, os LOD e LOQ encontrados são satisfatórios

Tabela10. Determinação de metais no efluente estudado

\begin{tabular}{|c|c|c|c|c|c|c|}
\hline Metais & $L O D$ & $L O Q$ & $\begin{array}{c}\text { Decreto no 8.468, de } \\
\text { setembro de } 1976 \\
(\mathrm{mg} / \mathrm{L})\end{array}$ & $\begin{array}{l}\text { Bruto* } \\
\text { (mg/L) }\end{array}$ & $\begin{array}{c}\text { Tratado** } \\
(\mathrm{mg} / \mathrm{L})\end{array}$ & $\begin{array}{l}\text { Lodo }(\mathrm{mg} / \mathrm{L}) \\
\text { (*** }\end{array}$ \\
\hline Al & 0,001 & 0,002 & $\left({ }^{*}\right)$ & $5,48 \pm 0,05$ & $0,15 \pm 0,06$ & $5,22 \pm 0,05$ \\
\hline $\mathrm{Pb}$ & 0,018 & 0,037 & 1,5 & $0,11 \pm 0,01$ & $<L O Q$ & $0,10 \pm 0,05$ \\
\hline $\mathrm{Cu}$ & 0,002 & 0,005 & 1,5 & $1,75 \pm 0,04$ & $<$ LOQ & $0,80 \pm 0,07$ \\
\hline $\mathrm{Cr}$ & 0,005 & 0,010 & 5,0 & $0,24 \pm 0,06$ & $<\mathrm{LOQ}$ & $0,10 \pm 0,05$ \\
\hline $\mathrm{Fe}$ & 0,018 & 0,037 & 15 & $31,3 \pm 0,08$ & $1,39 \pm 0,02$ & $26,65 \pm 0,22$ \\
\hline Mn & 0,012 & 0,024 & $\left({ }^{*}\right)$ & $0,09 \pm 0,02$ & $0,03 \pm 0,01$ & $0,06 \pm 0,03$ \\
\hline $\mathrm{Ni}$ & 0,011 & 0,023 & 2,0 & $0,22 \pm 0,06$ & $0,03 \pm 0,01$ & $0,04 \pm 0,04$ \\
\hline $\mathrm{Zn}$ & 0,009 & 0,018 & 5,0 & $5,68 \pm 0,12$ & $2,05 \pm 0,04$ & $3,67 \pm 0,05$ \\
\hline
\end{tabular}

(*): Valores não citados na lesgislação (Decreto no 8.468 , artigo 19A) * $\mathrm{pH}=5,84$ fluido de corte após o processo de usinagem; ${ }^{* \star} \mathrm{pH}=7,01$ fluido de corte após o tratamento com $\mathrm{EF} ;{ }^{* \star *} \mathrm{pH}=7,06$ lodo gerado após o tratamento.

Os valores representados em azul ultrapassam os limites máximos permitidos pela legislação para descartar o fluido de corte após o processo de usinagem em esgoto sem um prévio tratamento adequado para a remoção dos metais presentes. Em vermelho mostra que houve uma diminuição da concentração dos metais após o tratamento com a EF.

O fluido de corte após o tratamento teve seu $\mathrm{pH}$ aumentado de 5,84 para 7,01, o que indica aumento de $\mathrm{OH}^{-}$no processo. Devido às reações com os íons $\mathrm{OH}^{-}$ , diferentes formas de alumínio podem-se formar durante o processo eletrolítico. Com $\mathrm{pH}$ > 7,0 a formação de hidróxidos de alumínio solúveis é favorecida , com isso 
o alumínio gerado não participa de reações de coagulação, permancendo em solução principalmente na forma $\mathrm{Al}(\mathrm{OH})_{4}{ }^{-}$como mostra a página 22.

O alumínio presente no efluente teve uma redução de sua concentração, o que demonstra que o processo de EF não acarretou um aumento desse metal no efluente tratado devido o seu pH 7,01 conforme observado na Figura 14.

Os metais chumbo, cobre e cromo tiveram uma excelente redução de sua concentração, abaixo do LOQ, em comparação com os outros metais.

O lodo apresentou uma grande concentração de metais proveniente do tratamento como pode ser melhor demonstrado nas Figuras 14 e 15, isso pode significar que os metais podem não estar sendo totalmente adsorvidos nos eletrodos de alumínio.

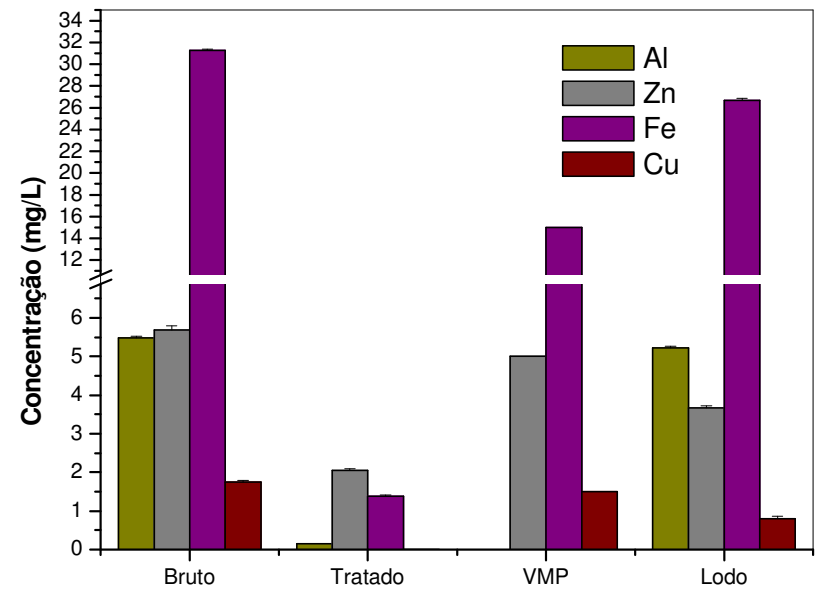

Figura14: Concentração de metais

Bruto: fluido de corte após o processo de usinagem; Tratado: fluido de corte após o tratamento com a EF; VMP : valores permitidos pelo Decreto $n^{\circ}$ 8.468, de setembro de 1976; Lodo : parte removida dos poluentes durante a EF.

De acordo com a Figura 14 verifica-se que há uma grande quantidade de ferro no fluido após a usinagem. Assim, não seria viável para remoção desse metal a utilização de eletrodos de ferro no processo de EF, pois acarretaria um aumento desse metal após o tratamento. Segundo Crespilho et al (2004), em condições 
ácidas ou neutras o $\mathrm{Fe}^{+2}$ apresentam solubilidade elevada e podem ser oxidados facilmente a $\mathrm{Fe}^{3+}$ pelo oxigênio dissolvido na água o que gera uma coloração esverdeada no efluente tratado.

Conforme está representado nas Figuras 14 e 15 o fluido de corte após o processo de tratamento com a EF pode ser descartado em esgoto já que as concentrações de todos metais avaliados diminuíram em comparação com o valor estipulado pela legislação. No entanto, há alumínio e manganês, que, embora não contemplado na legislação deve ser considerado.

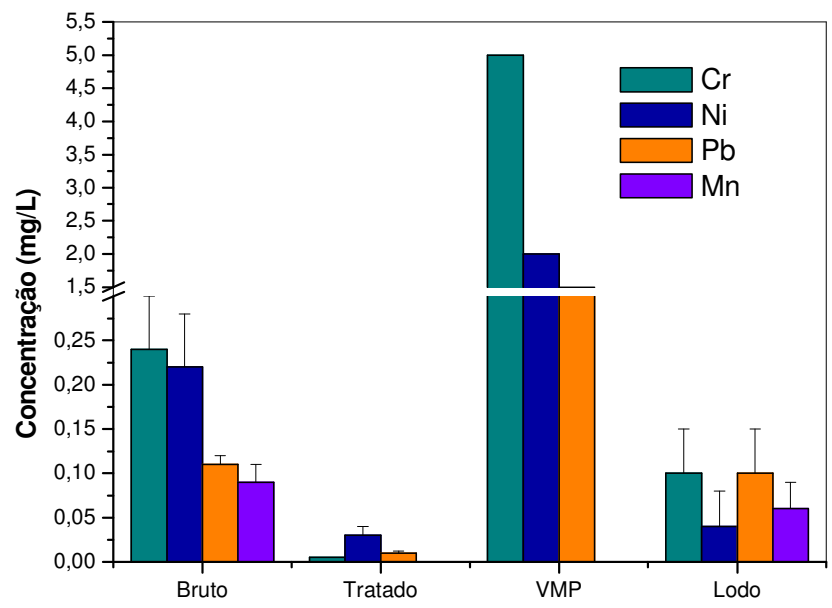

Figura15: Concentração de metais

Bruto: fluido de corte após o processo de usinagem; Tratado: fluido de corte após o tratamento com a EF; VMP : valores permitidos pelo Decreto n 8.468, de setembro de 1976; Lodo : parte removida dos poluentes durante a EF.

Pode-se verificar que o metal que fica menos retido nas placas de alumínio é o chumbo, devido a maior parte estar presente no lodo quando se faz o tratamento do fluido de corte, porém ocorre o contrário em relação ao níquel como mostra a Figura 15. 


\subsubsection{Adsorção de metais nos eletrodos de Alumínio}

Após diversos tratamentos do fluido de corte com a EF foi verificado que parte dos metais presentes no resíduo não são totalmente removidos para o lodo, ficando adsorvidos nos eletrodos de alumínio como mostra as Figura 14 e 15.

A água ultra purificada utilizada na EF para a verificação da adsorção de metais foi analisada antes do processo de EF e não constou nenhuma das espécies metálicas em estudo.

De acordo com a Figura 16 pode-se dizer que os metais adsorvidos nas placas foram liberados para a água ultra-purificada durante o processo de EF, porém foi constatado baixas concentrações devido os eletrodos já terem sido utilizados diversas vezes.

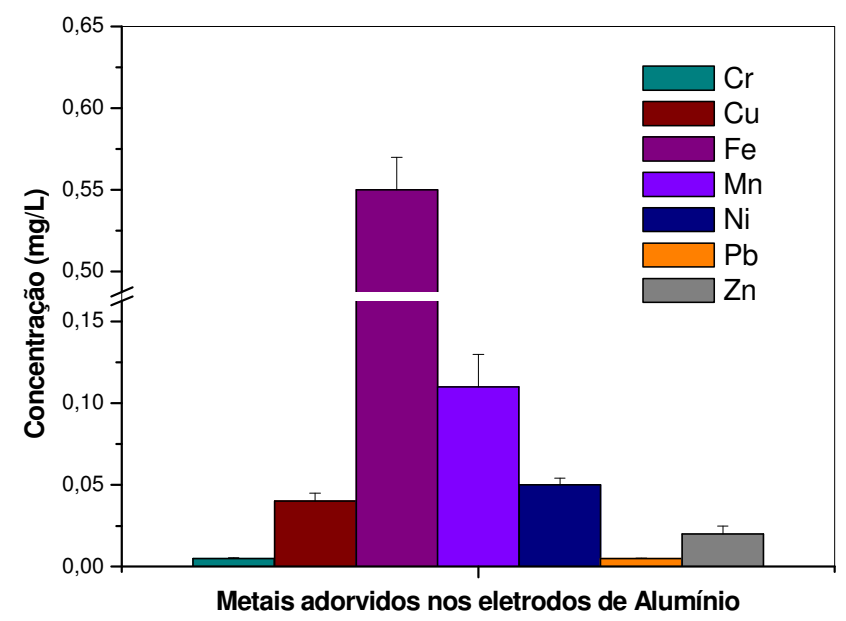

Figura 16: Concentração dos metais adsorvidos nas placas de alumínio após vários tratamentos do fluido de corte com a EF.

Como foi analisado anteriormente, a maior concentração dos metais removidos do resíduo ficam realmente dispostos no lodo. 


\subsection{Determinação de Carbono Orgânico Total (COT)}

O resíduo em estudo possui inúmeros compostos orgânicos que podem conter cargas superficiais dependendo do $\mathrm{pH}$ como, por exemplo, grupos carboxílicos, fosfatos e aminas. Podem ocorrer reações químicas entre as substâncias orgânicas e a superfície dos colóides formados pelo hidróxido de alumínio dando origem aos colóides maiores.

As moléculas orgânicas que contém grupamentos alifáticos não interagem com as moléculas de água, com isso os colóides podem ser removidos, pela geração de hidrogênio e oxigênio, para a parte superior do reator (BERNARDO,1993).

A Figura 17 representa a curva de calibração para determinação de COT com biftalato de potássio.

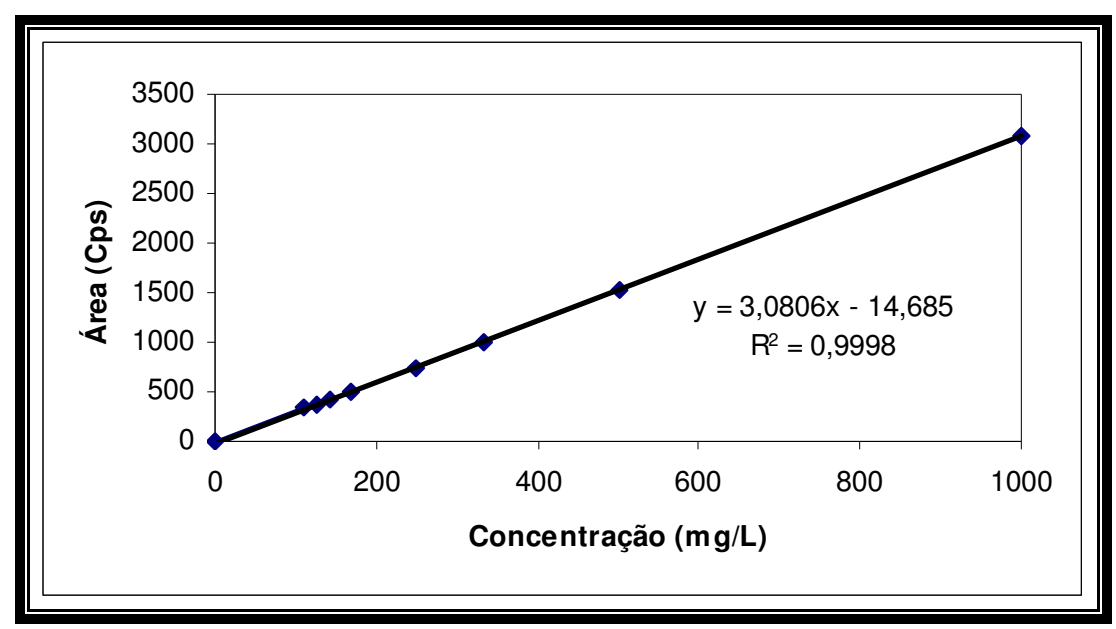

Figura17: Curva analítica para determinação de COT. 
Na Figura 18, estão apresentados os resultados da redução da concentração de COT, em função do tempo de tratamento. A cada 5 min de tratamento nota-se que tem uma diminuição da concentração de COT.

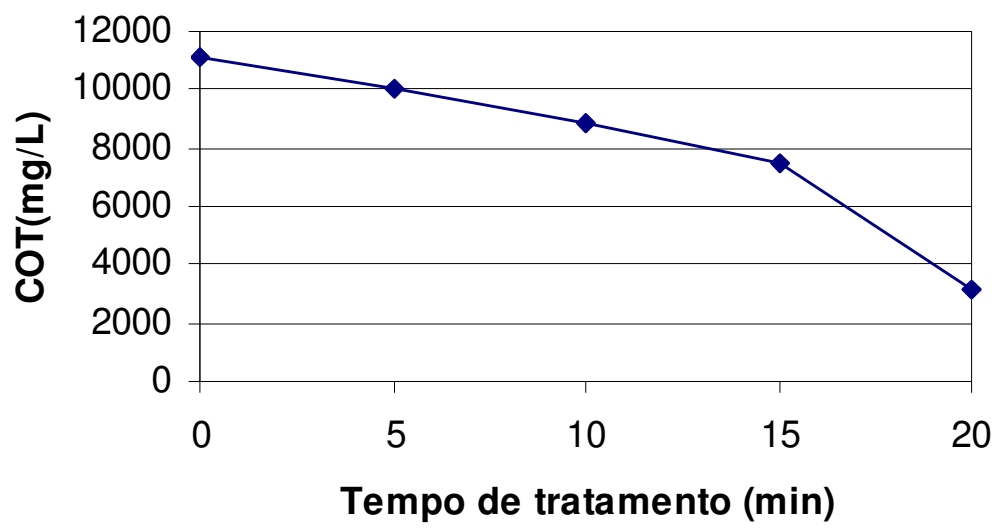

Figura 18: Relação entre a determinação de COT sem a inversão da polaridade em função do tempo de tratamento com uma corrente de 0,75A.

A quantidade de COT no resíduo bruto é muito elevada (11435mg/L). A EF mostrou-se eficiente na remoção de COT, removendo 72,3\% de carbono orgânico.

\subsubsection{Determinação de sólidos totais, carbono orgânico total e óleos e} graxas

A determinação da concentração de sólidos totais envolve todos os compostos particulados e dissolvidos como metais, sais inorgânicos, óleos e graxas e matéria orgânica presente no efluente em estudo.

Na Figura 19 apresentam-se os resultados da redução de COT, sólidos totais e óleos e graxas antes e após o processo de EF. Pode-se observar que a maioria dos compostos presentes no fluido de corte após a usinagem são compostos orgânicos provenientes de óleos e graxas. 
A quantidade de sólidos totais presente no resíduo bruto foi de $11700 \mathrm{mg} / \mathrm{L}$, após a EF houve uma redução de $55,3 \%$. A concentração de óleos e graxas foi de $9942 \mathrm{mg} / \mathrm{L}$ e teve uma redução de $93,4 \%$. A redução de COT foi de $72,3 \%$.

Pode-se considerar que a EF foi eficiente na remoção de óleos e graxas, porém a legislação para o descarte requer uma concentração de $150 \mathrm{mg} / \mathrm{L}$, o tratado ainda apresenta uma concentração muito elevada $(654 \mathrm{mg} / \mathrm{L})$ para o descarte. Seria viável um segundo processo de EF para uma melhor remoção.

A quantidade de sólidos dissolvidos não removidos deve-se a presença no efluente tratado de sais que dificilmente são removidos e metais. A quantidade de carbono orgânico não removida se deve a grandes quantidades de compostos poliméricos presentes no fluido de corte sintético, e aos agentes emulsificantes (ou surfactantes) que são substâncias adicionadas às emulsões para aumentar a sua estabilidade cinética tornando-as razoavelmente estáveis e homogêneas.

Tabela 11. Eficiência da EF na remoção de poluentes.

\begin{tabular}{ccc}
\hline Caracterização & Bruto & Tratado \\
\hline Sólidos totais dissolvidos & $11700,0 \pm 0,5$ & $5225,0 \pm 0,5$ \\
COT & $11435,0 \pm 0,4$ & $3168,0 \pm 0,5$ \\
Óleos e graxas & $9942,0 \pm 0,2$ & $654,0 \pm 0,6$ \\
\hline
\end{tabular}




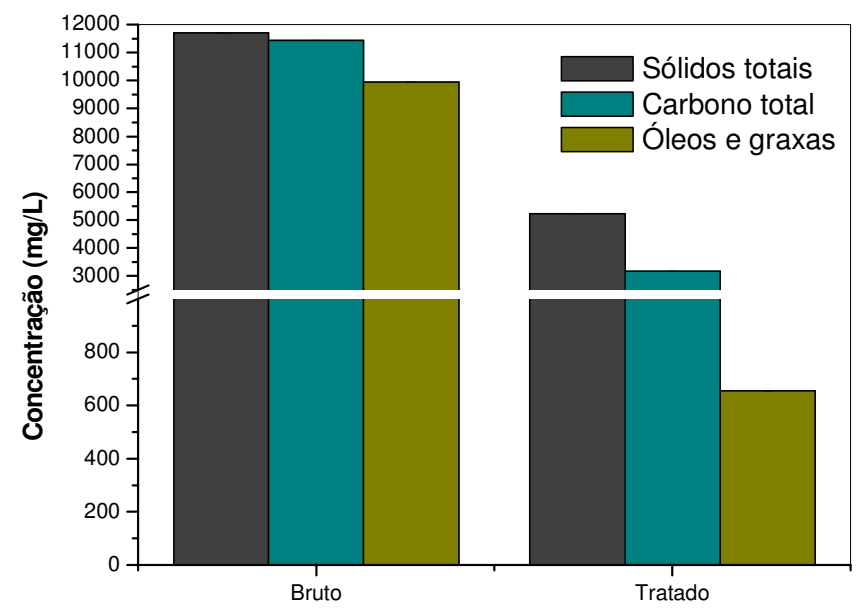

Figura19: Eficiência da remoção de sólidos totais dissolvidos, carbono orgânico total e óleos e graxas. Bruto : resíduo após a usinagem; Tratado: resíduo após o processo de EF com uma correntede $0,75 \mathrm{~A}$.

\subsubsection{Determinação da DBO e DQO}

Os maiores aumentos em termos de $\mathrm{DBO}_{5,20}$, são provocados por despejos de origem predominantemente orgânica.

A DQO apresenta valores normalmente maiores que os da DBO como mostra a Tabela 12, pois, para sua determinação, além da oxidação do material orgânico, há oxidação de alguns compostos como gordura, que se biodegradam muito lentamente, e alguns íons em solução. A relação DBO/DQO fornece uma estimativa da parcela de matéria orgânica contida em uma água residuária que pode ser estabilizada por via biológica (VON SPERLING,1996).

Na legislação do Estado de São Paulo, o Decreto Estadual n.ㅇ468, a $\mathrm{DBO}_{5,20}$ é padrão de emissão de esgotos diretamente nos corpos d'água, sendo exigidos uma $\mathrm{DBO}_{5,20}$ máxima de $60 \mathrm{mg} / \mathrm{L}$ ou uma eficiência global mínima do processo de tratamento na remoção de $\mathrm{DBO}_{5,20}$ igual a $80 \%$. Este último critério favorece aos efluentes industriais concentrados, que podem ser lançados com valores de $\mathrm{DBO}_{5,20}$ ainda altos, mesmo removida acima de $80 \%$. 
Tabela 12. Eficiência da EF na redução da $D B O$ e $D Q O$

\begin{tabular}{ccc}
\hline Caracterização & Bruto $^{*}$ & Tratado $^{\star *}$ \\
\hline DBO $(\mathrm{mg} / \mathrm{L})$ & $5000,0 \pm 0,1$ & $120,0 \pm 0,1$ \\
DQO $(\mathrm{mg} / \mathrm{L})$ & $17000,0 \pm 0,2$ & $8000,0 \pm 0,1$ \\
DQO/DBO & $3,4 \pm 0,2$ & $66,7 \pm 0,1$ \\
\hline $\begin{array}{l}\text { Bruto* } \\
\text { 0,75A. resíduo após a usinagem; }\end{array}$
\end{tabular}

Pelo fato de a $\mathrm{DBO}_{5,20}$ somente medir a quantidade de oxigênio consumido num teste padronizado, não indica a presença de matéria não biodegradável, nem leva em consideração o efeito tóxico ou inibidor de materiais sobre a atividade microbiana.

Os valores de DQO são superiores aos de DBO, devido ao fato já mencionado anteriormente, ou seja, mais compostos podem ser quimicamente oxidados do que biologicamente oxidados.

Como na $\mathrm{DBO}_{5,20}$ mede-se apenas a fração biodegradável, quanto mais este valor se aproximar da DQO significa que mais facilmente biodegradável será o efluente ( CETESB,2006).

Von SPERLING (1996) afirma que a relação DQO/DBO tende a aumentar à medida que a água residuária passa pelas diferentes etapas do tratamento, pois ocorre uma redução paulatina da fração biodegradável enquanto a fração inerte permanece aproximadamente inalterada. A relação DQO/DBO como mostra a Tabela 12 aumenta após o tratamento, pois a EF reduz a fração biodegradável.

Pode-se observar pela Figura 20 que o resíduo bruto apresenta uma maior redução da DBO (98,5\%) do que da DQO (70,1\%). Como o resíduo apresentou uma redução de $72,3 \%$ de carbono orgânico, pode-se dizer que a maior parte dos compostos presentes no resíduo são orgânicos, já que a DQO apresentou praticamente o mesmo valor de redução. 


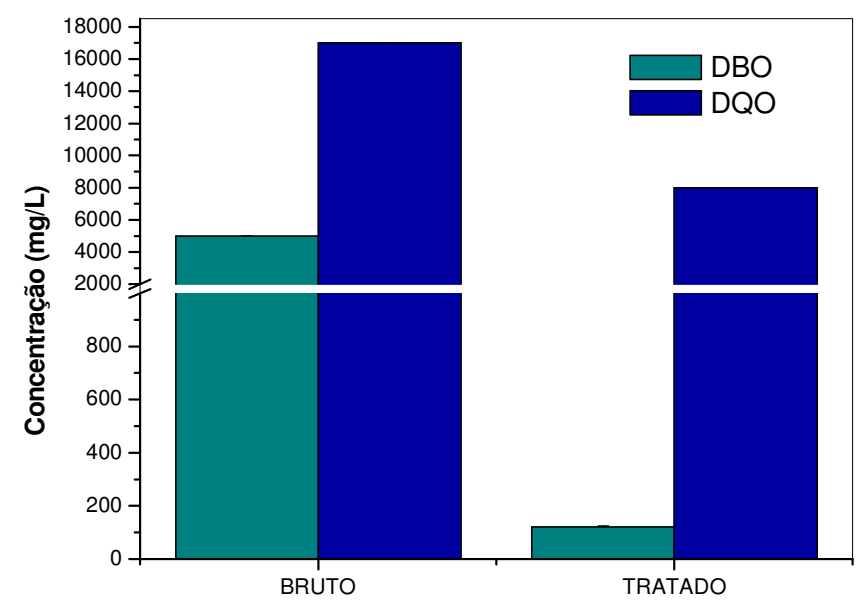

Figura 20: Determinação de DBO e DQO; Bruto : resíduo após a usinagem; Tratado: resíduo após o processo de EF com uma corrente de 0,75A.

\subsection{Determinação da Turbidez e Condutividade}

O fluido de corte tratado está mais clarificado apresentando uma baixa turbidez como mostra a Tabela 13, isso se deve a redução de óleos e graxas, matéria orgânica e sólidos dissolvidos.

Tabela13. Eficiência da EF nos valores de turbidez e condutividade

\begin{tabular}{ccc}
\hline Caracterização & Bruto & Tratado \\
\hline Turbidez (NTU) & $26300,0 \pm 0,3$ & $6,9 \pm 0,1$
\end{tabular}

Condutividade $(\mathrm{mS} / \mathrm{cm}) \quad 1775,0 \pm 0,5 \quad 2450,0 \pm 0,2$

Bruto: resíduo após a usinagem; Tratado: resíduo após o processo de EF com uma corrente de $0,75 A$.

O Bruto apresenta uma baixa condutividade em comparação com o tratado pois antes de iniciar o processo de $\mathrm{EF}$ foi adicionado $\mathrm{NaCl}$ para a melhorar a eficiência da EF. Um dos critérios que envolvem a EF é a necessidade de se trabalhar com soluções de alta condutividade para se obter resultados. 


\subsection{Determinação de nitrogênio e nitrito}

As espécies nitrogenadas presentes no fluido de corte devem-se a presença de compostos orgânicos. A Figura 21 mostra uma elevada concentração de nitrogênio kjeldahl (165mg/L) no resíduo bruto, com uma redução de 63,6\% . O lodo apresentou $29,0 \%$ de nitrogênio em relação ao bruto.

Os nitritos presentes no fluido de corte após o processo de usinagem com ação anticorrosiva, apresentou uma concentração de 295mg/L com redução de $96,6 \%$. O lodo gerado como mostra a Figura 22 apresentou $84,7 \%$ de nitrito em relação ao bruto.

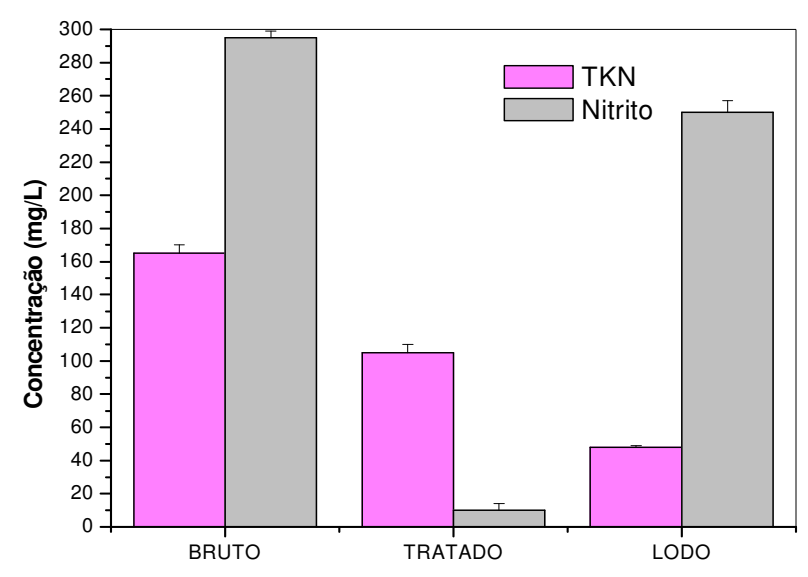

Figura 21: Determinação de nitrogênio Kjeldahl e nitrito

Bruto : resíduo após a usinagem; Tratado: resíduo após o processo de EF com uma corrente de 0,75A Lodo: parte removida dos contaminates.

A remoção de nitritos no resíduo foi mais eficiente do que a remoção de nitrogênio orgânico utilizando a EF. Como o resíduo em estudo apresenta em sua composição compostos orgânicos contendo nitrogênio em sua estrutura é mais dificultada a sua remoção em comparação com nitritos, que apresentam cargas. 


\subsection{Fósforo total}

A maior parte do fósforo presente no fluido de corte está na forma de fosfatos, que são adicionados ao fluido com a propriedade anti-corrosiva e para a melhor aderência do óleo lubrificante.

O resíduo bruto apresenta uma grande quantidade de fosfatos $(9667 \mathrm{mg} / \mathrm{L})$ como mostra a Figura 22. O tratado apresentou $31,0 \%$ da quantidade de fosfato, já o lodo $68,9 \%$. A EF mostrou uma grande eficiência na remoção de fosfatos.

A precipitação do fosfato é conseguida pela adição de um metal. O hidróxido de alumínio, agente coagulante, pode precipitar os fosfatos presentes no efluente entre um pH 6,0 a 8,5 (JENKINS, HERMANOWICZ ,1991; DROSTE,1997).

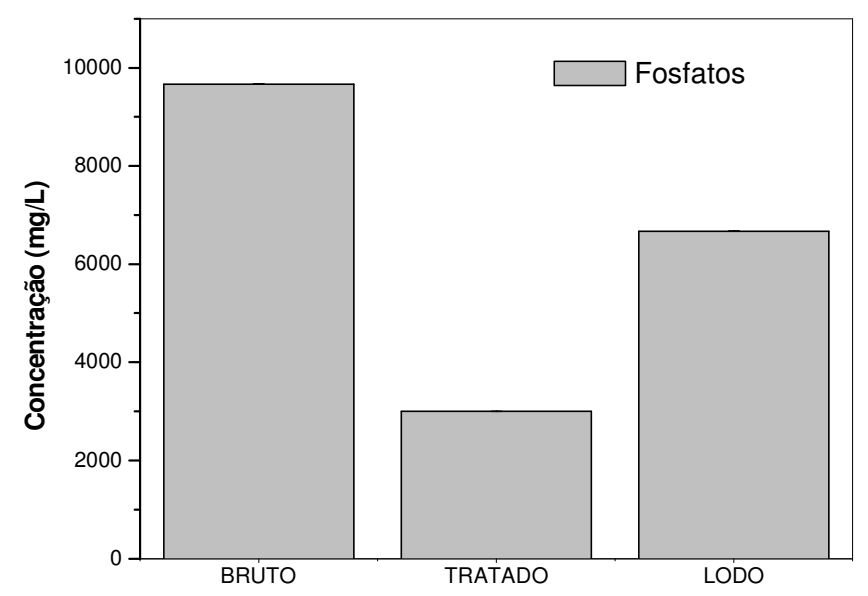

Figura 22: Concentração de fosfatos

Bruto : resíduo após a usinagem; Tratado: resíduo após o processo de EF com uma corrente de 0,75 A; Lodo : parte removida dos contaminates.

Um aumento incontrolado da concentração de fosfato em rios e lagos terá consequências desastrosas na medida em que provocará um crescimento incontrolado de algas, causando um desequilíbrio da vida aquática. 
Para águas doces uma concentração até $0,5 \mathrm{mg} / \mathrm{L}$ de fosfato é aceitável, porém não deverá exceder $1 \mathrm{mg} / \mathrm{L}$. Considera-se $0,02 \mathrm{mg} / \mathrm{L}$ uma concentração suficiente para satisfazer as necessidades nutritivas das plantas (NISHINO, 1994).

O resíduo conhecido como "borra de fosfato" é gerado em indústrias que possuem em seu processo produtivo a etapa de pintura em superfícies metálicas (montadoras, fabricantes de autopeças, máquinas diversas, móveis, eletrodomésticos, etc). Este resíduo é, na maioria das vezes disposto inadequadamente em aterros sanitários e/ou lixões. Em alguns casos, é encaminhado para aterros industriais, ou tratado através de processos como o de resina de troca iônica (NISHINO, 1994).

Algumas aplicações para a borra de fosfato têm sido estudadas, como a fabricação de fertilizantes ou para a composição de asfalto e agregados da construção civil. A construção civil é um ramo da atividade tecnológica, que, pelo volume de recursos naturais consumidos, pode ser largamente indicado para absorver resíduos sólidos (JOHN,1999).

\subsection{Análises Cromatográficas}

A Figura 23 apresenta o cromatograma obtido do fluido de corte antes e após o mesmo ser utilizado no processo de usinagem. O fluido de corte apresenta BTEX e HPAs em sua formulação (1 e 2), porém, a contaminação pelo óleo presente na peça usinada e a alta temperatura na região de contato peça-ferramenta causa a contaminação ou a formação de compostos tóxicos que pode ser observado nos cromatogramas de BTEX e HPAs após o processo de usinagem (3 e 4). 

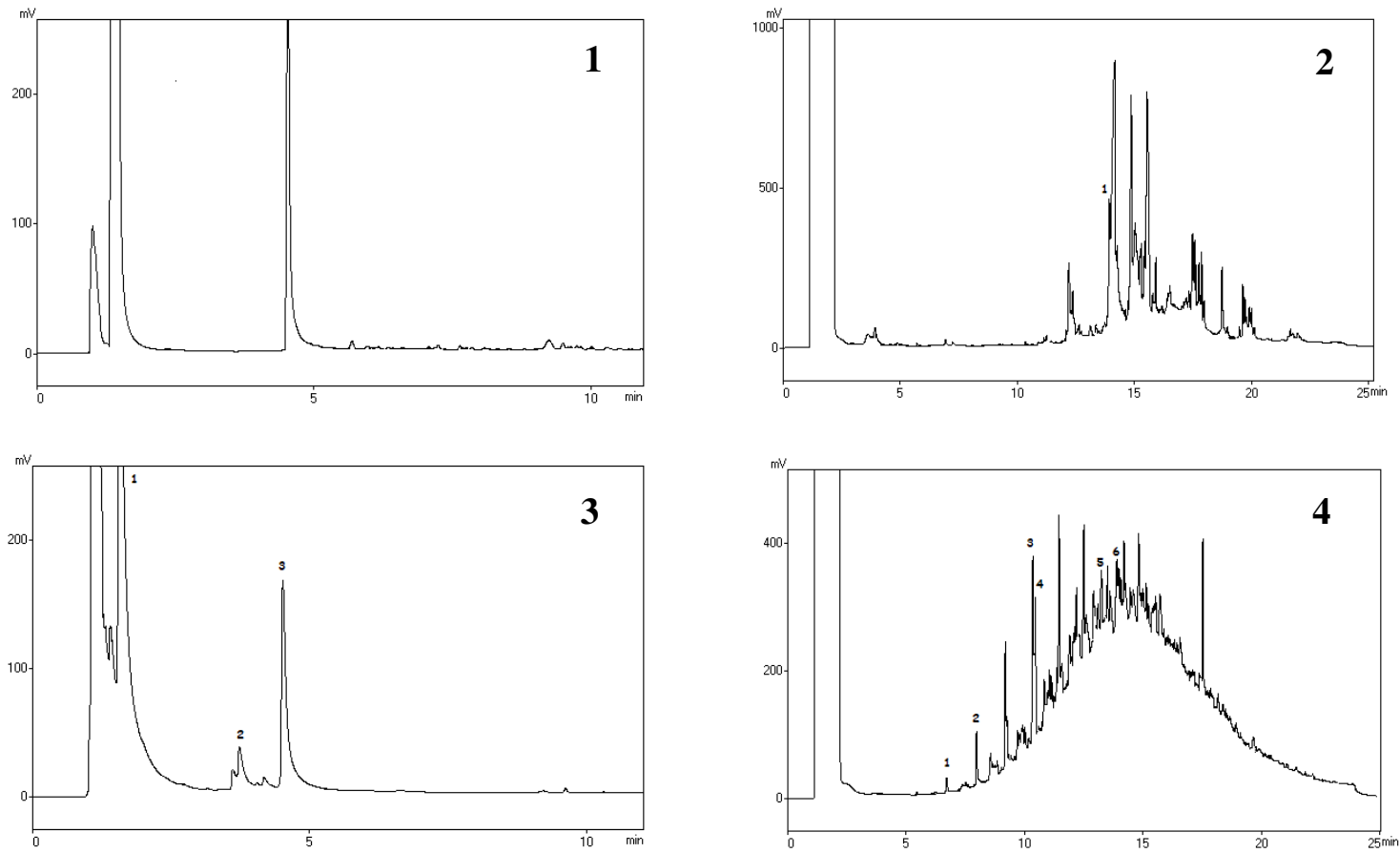

Figura 23: Análise de BTEX e HPAs antes e após o processo de usinagem: 1 e 2 fluido de corte antes do processo de usinagem - BTEX e HPAs respectivamente; 3 e 4 fluido de corte após o processo de usinagem - BTEX e HPAs respectivamente.

Para o fluido de corte antes do processo de usinagem: no cromatograma 1 encontra-se uma concentração de 29,31 mg/L de xileno (o) (pico 1) e 15,8586 $\mathrm{mg} / \mathrm{L}$ de pireno (pico 1) no cromatograma 2. Esses compostos também estão presentes no resíduo de fluido juntamente com outros compostos.

O fluido de corte destinado ao descarte apresentou os seguintes compostos e concentrações (Tabela 14 e 15). 
Tabela 14: Concentrações de BTEX no resíduo de fluido de corte

\begin{tabular}{ccc}
\hline & \multicolumn{2}{c}{ BTEX } \\
Pico & Composto & Conc. $(\mathbf{m g} / \mathbf{L})$ \\
1 & Benzeno & $107,0869 \pm 0,0001$ \\
2 & Etilbenzeno & $5,2949 \pm 0,0001$ \\
3 & Xileno (o) & $10,27 \pm 0,01$ \\
\hline
\end{tabular}

Tabela15: Concentrações de HPAs no resíduo fluido de corte

\begin{tabular}{ccc}
\hline & \multicolumn{2}{c}{ HPAs } \\
Pico & Composto & Conc. $(\mathrm{mg} / \mathrm{L})$ ) \\
1 & Acenafteno & $10,6791 \pm 0,0001$ \\
2 & Fluoreno & $45,6844 \pm 0,0001$ \\
3 & Fenantreno & $103,7531 \pm 0,0001$ \\
4 & Antraceno & $70,2600 \pm 0,0001$ \\
5 & Fluoranteno & $109,9124 \pm 0,0001$ \\
6 & Pireno & $120,1975 \pm 0,0001$ \\
\hline
\end{tabular}

Os resultados da análise de HPAs encontram-se na Figura 24. O resultado obtido no Experimento 1 (após 20 min de tratamento) foi melhor em comparação com o Experimento 02 (após 10 minutos de tratamento) sem inversão de polaridade. No primeiro não há presença de HPAs, enquanto que no experimento 02 foi detectada a presença como pode ser verificada na tabela 16.

No lodo gerado após o processo de Eletroflotação (Experimento 03) foi verificado a presença de HPAs como pode ser visto na Figura 24, e também houve a extração de outros compostos presentes no fluido de corte. A Tabela 16 apresenta os compostos encontrados no Experimento 03 
Tabela 16: Concentração de HPAs encontrados no Experimento 02 e 03

\begin{tabular}{cccc}
\hline Pico & Composto & $\begin{array}{c}\text { Experimento 02 } \\
\text { Conc. }\left(\mathrm{mg} \mathrm{L}^{-1}\right)\end{array}$ & $\begin{array}{c}\text { Experimento } 03 \\
\text { Conc. }\left(\mathrm{mg} \mathrm{L}^{-1}\right)\end{array}$ \\
\hline 1 & Acenafteno & $0,8678 \pm 0,0001$ & $12,7524 \pm 0,0002$ \\
2 & Fluoreno & $1,6282 \pm 0,0001$ & $112,3043 \pm 0,0001$ \\
3 & Fenantreno & $1,9112 \pm 0,0001$ & $84,9522 \pm 0,0002$ \\
4 & Antraceno & $1,0819 \pm 0,001$ & $49,9364 \pm 0,0001$ \\
5 & Fluoranteno & $0,9120 \pm 0,0002$ & $52,9898 \pm 0,0001$ \\
6 & Pireno & Nada consta & $13,6888 \pm 0,0002$ \\
\hline
\end{tabular}
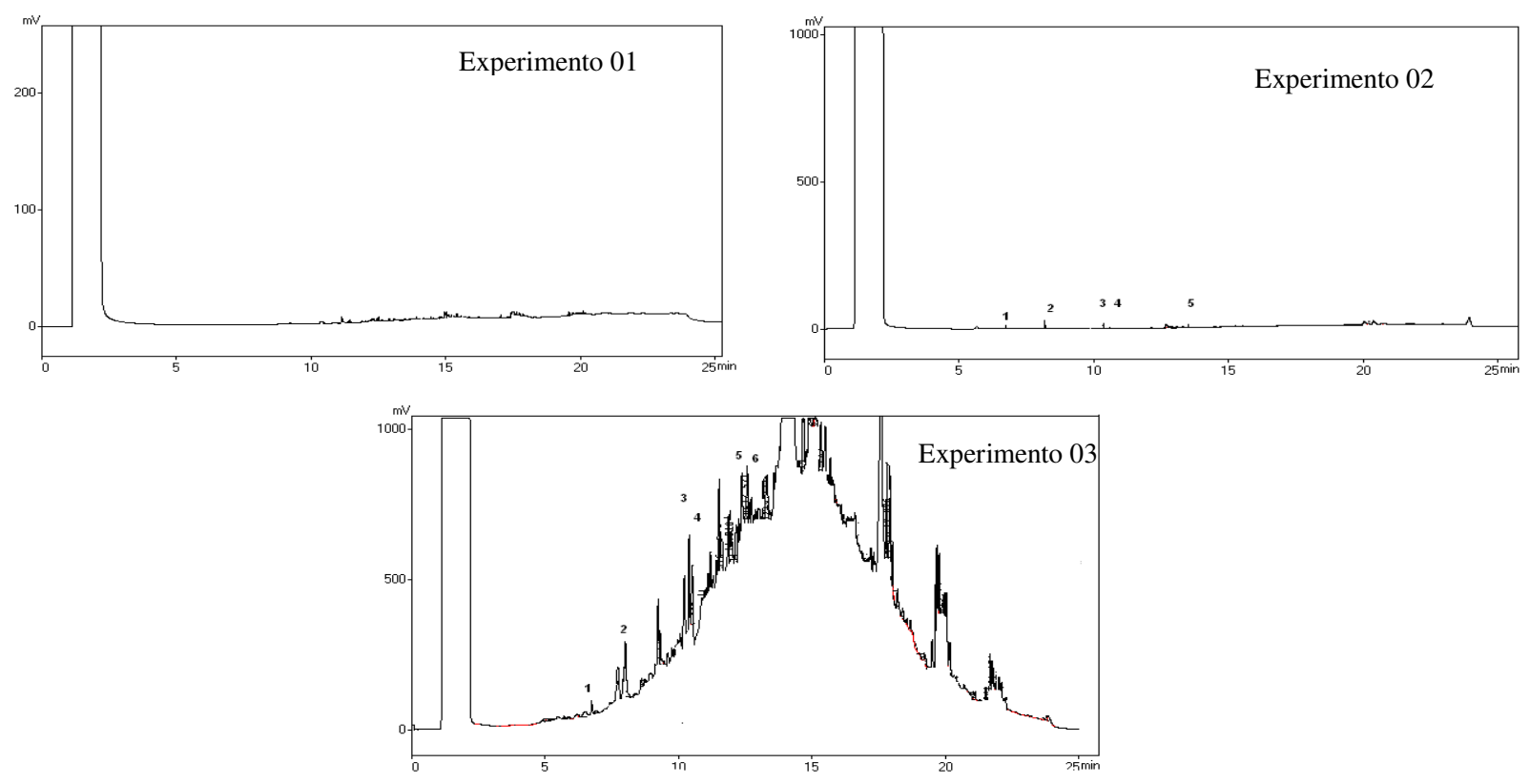

Figura 24: Análise de HPAs para os experimentos utilizando Eletroflotação após 20 min (Experimento 01 e 03) e após 10 min(Experimento 02).

Para a análise de BTEX, Figura 25, o processo após 10 minutos de tratamento (Experimento 05) apresentou picos dos compostos estudados, já após 20 minutos (Experimento 04) não foi encontrado BTEX. Na análise de HPAs, faz-se o 
uso de extração por meio de solvente, dessa forma, existindo outro composto que possa ser extraído, ele originará um pico no espectro.

No lodo gerado apos 20 minutos de tratamento (Experimento 06) foi constatado apenas a presença de benzeno como pode ser verificado na Tabela 17, provavelmente por ser mais facilmente volatilizado durante a análise.

Tabela 17: Concentração de BTEX encontrados no Experimento 05 e 06.

\begin{tabular}{cccc}
\hline Pico & Composto & $\begin{array}{c}\text { Experimento 05 } \\
\text { Conc. }\left(\mathrm{mg} \mathrm{L}^{-1}\right)\end{array}$ & $\begin{array}{c}\text { Experimento 06 } \\
\text { Conc. }\left(\mathrm{mg} \mathrm{L}^{-1}\right)\end{array}$ \\
\hline 1 & Benzeno & Nada consta & $89,0467 \pm 0,0001$ \\
3 & Etilbenzeno & $0,450 \pm 0,002$ & Nada consta \\
3 & Xileno (o) & $0,065 \pm 0,001$ & Nada consta \\
\hline
\end{tabular}
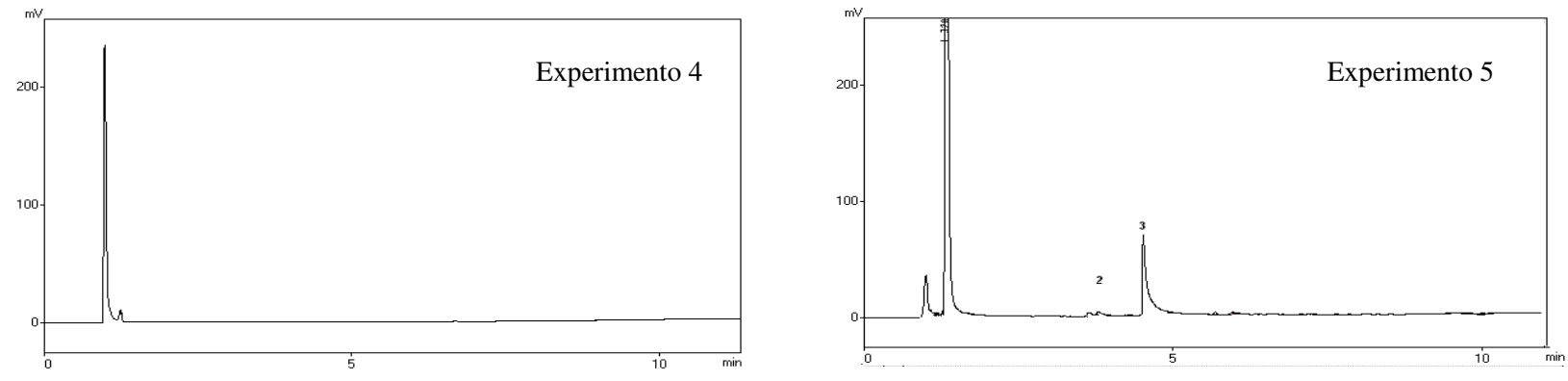

1

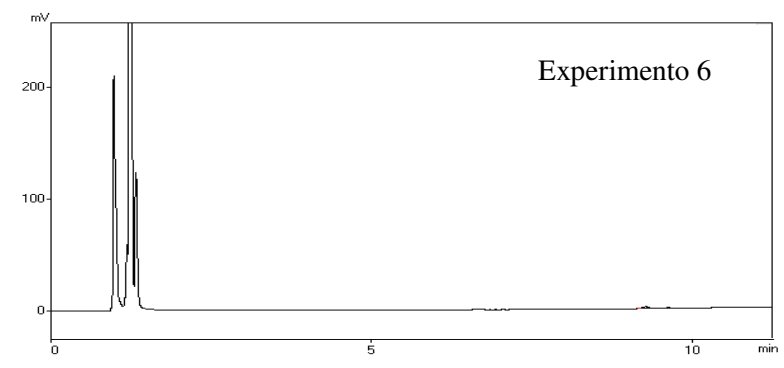

Figura 25: Análise de BTEX para os experimentos utilizando Eletroflotação após 20 min (Experimento04 e 06) e após 10 min (Experimento 05). 
A Figura 26 apresenta a análise de nitrosaminas do fluido de corte antes e após o mesmo ser utilizado no processo de usinagem. Observa-se que após o processo de usinagem há uma grande quantidade de compostos que foram formados ou agregados à solução durante o processo. Essa grande quantidade de compostos dificulta a interpretação dos cromatogramas, mas a análise dos resultados não revelou a presença de nitrosaminas após o processo de usinagem para o fluido em estudo.
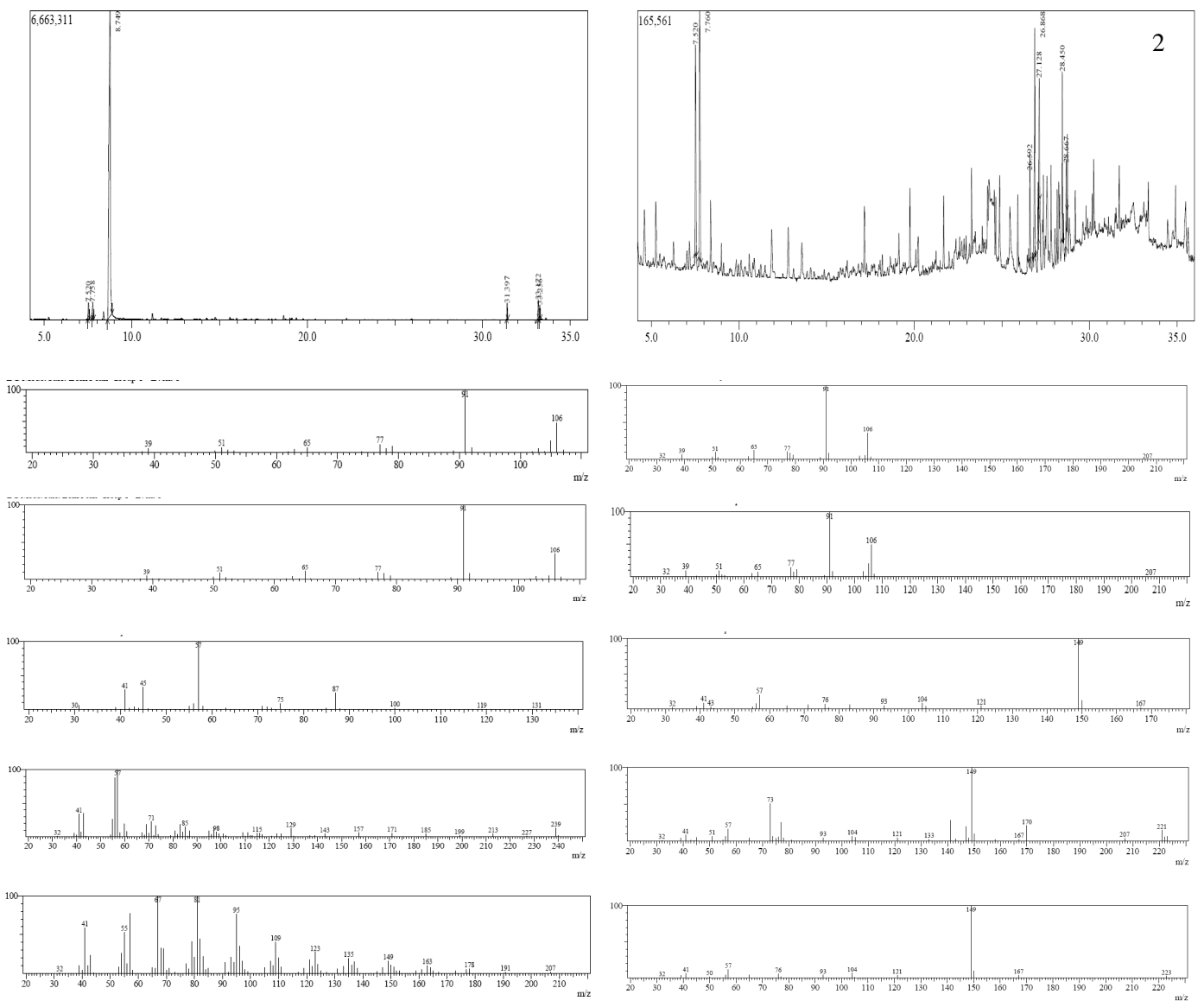

Figura 26: Cromatograma de amostras de fluido de corte antes (1) e após (2) o processo de usinagem, os espectros de massa estão abaixo de cada cromatograma e representam os cinco primeiros picos do espectro. 
A Figura 27 apresenta os cromatogramas do fluido de corte tratado (Experimento 07) e o lodo gerado (Experimento 08) após 20 minutos de tratamento.
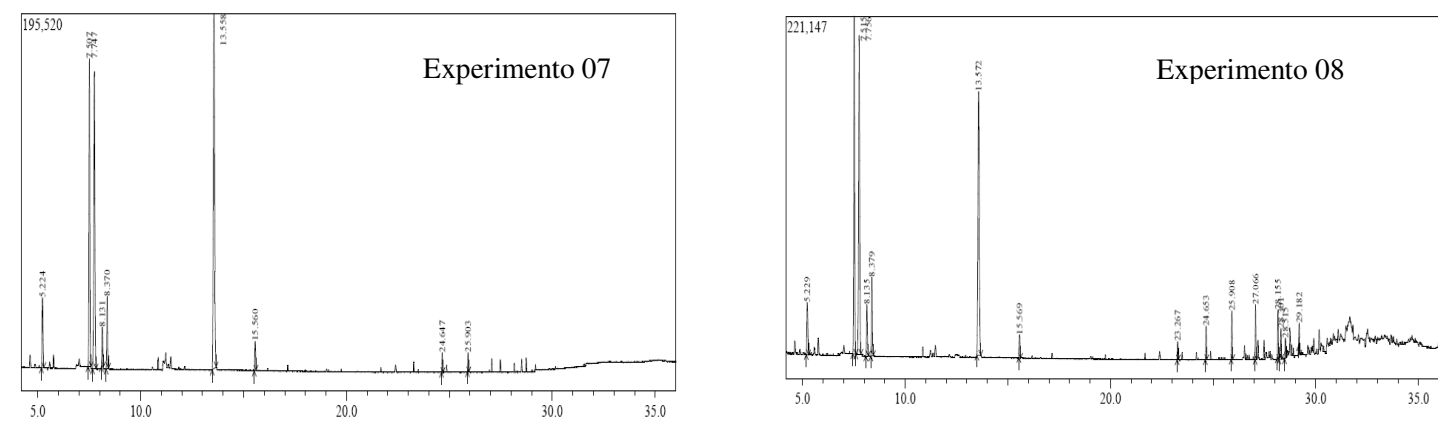

Figura 27: Análise de BTEX para os experimentos utilizando Eletroflotação após 20 min: Tratado (Experimento07) e o lodo (Experimento 08)

Como era de esperar os cromatogramas dos Experimentos 07 e 08 não apresentaram picos referentes às nitrosaminas apesar de haver grande quantidade de compostos.

\subsubsection{Disposição final do Lodo}

Diversos projetos de tratamento de efluentes não contemplam o destino final do lodo produzido e com isso anulam-se parcialmente os benefícios da coleta e do tratamento dos resíduos. Assim, há necessidade de desenvolver alternativas seguras para que esse produto não se transforme em um novo problema ambiental, mas sim tirar vantagens ambientais de sua disposição.

As alternativas mais usuais para a disposição final do lodo de esgoto são: aterro sanitário; reuso industrial (produção de agregado leve, fabricação de tijolos e cerâmica e produção de cimento); incineração; conversão em óleo combustível; recuperação de solos (recuperação de áreas degradadas e de mineração) e uso agrícola e florestal. Entre as diversas alternativas existentes, aquela para fins agrícola e florestal apresenta-se como uma das mais convenientes, pois, como o 
lodo é rico em matéria orgânica e nutrientes para as plantas (nitrogênio e fosfatos), seria possível a sua aplicação como condicionador de solo e ou fertilizante (BETTIOL,CAMARGO,2000).

Entretanto, o lodo gerado no tratamento do resíduo em estudo apresenta em sua composição diversos poluentes como, metais pesados, nitritos, ácidos orgânicos, compostos aromáticos polinucleares e nitrosaminas. "potencialmente carcinogênicos".

Segundo a resolução CONAMA 9/93 proibe-se qualquer descarte de óleo usado em solos, águas superficiais, águas subterrâneas, no mar territorial e em sistemas de esgoto ou evacuação de águas residuais.

Nos casos quando não seja possível a regeneração do lodo proveniente do tratamento, como é o caso do resíduo, o órgão ambiental competente poderá autorizar a sua combustão, para aproveitamento energético ou incineração para destruição de produtos tóxicos. A combustão, para aproveitamento energético, não seria viável devido a presença de substâncias tóxicas.

A EF mostrou eficiência na remoção parcial dos contaminantes presentes no fluido de corte, porém a concentração de óleos e graxas ultrapassou o limite máximo para o descarte conforme a legislação pertinente.

O tratamento realizado a partir de $550 \mathrm{~mL}$ de efluente, gerou aproximadamente $62 \mathrm{~mL}$ de lodo. Portanto, houve uma ótima quantidade de resíduo tratado. A vantagem da Eletroflotação no tratamento foi a redução do volume de resíduo (lodo) a ser destinado para um segundo tratamento. 


\section{CONCLUSÃO}




\section{Conclusão}

Podemos concluir que a utilização da inversão da polaridade durante 0 processo de EF não resulta uma melhor eficiência na remoção de contaminantes do fluido de corte. O teor de sólidos totais dissolvidos não difere significativamente sem o uso da inversão com mesmo tempo de tratamento.

Os resultados mostram uma excelente remoção de metais para o lodo, inclusive o alumínio gerado no processo de EF, não acarretando a geração de um novo poluente. A adsorção de metais nas placas de alumínio, proveniente de vários processos de EF com fluido de corte obteve baixas concentrações.

O resíduo apresentou uma elevada concentração de óleos e graxas para descarte de acordo com a legislação, após a EF obteve-se uma remoção de 90\%.

A presença de compostos tóxicos como BTEX e HPAs inviabiliza um estudo para propor a utilização do lodo na agricultura mesmo sendo rico em nutrientes, como nitrogênio e fosfatos. Devido à presença de cargas no resíduo não há alteração de condutividade durante o processo de EF.

A vantagem da EF no tratamento proposto neste trabalho foi a redução da quantidade de resíduo (lodo) a ser destinada para um segundo tratamento.

\section{Trabalhos Futuros}

Os resultados obtidos com este trabalho viabilizam estudar o processo em escala maior como um pré-tratamento do resíduo fluido de corte sintético. 


\section{REFERÊNCIAS}

\section{BIBLIOGRÁFICAS}




\section{Referências Bibliográficas}

ADAMS, W.J. Aquatic toxicology testing methods. In: HOFFMAN, D.; RATTNER,B.A.; BURTON JUNIOR.; G.A.; CAIRNS JUNIOR., J. Handbook of ecotoxicology. Boca Raton: Lewis Publications, 1995. P. 27-45.

AMERICAN SOCIETY FOT TESTING AND MATERIALS. Standard test methods for chemical oxygen demand (dichromate oxygen demand) of water. Philadelphia: ASTM, 1995. D 1252-95.

BANDE, R. M.; PRASAD, B. ; MISHRA, I.M.; WASEWAR, K. L. Oil field effluent water treatment for safe disposal by electroflotation. Chem. Engin. Jour., in press.

BARADIE, M. A. E.I. cutting fluids: part i. characterisation. Journal of Materials Processing Thechnology. n. 56, p. 786-797. 1996.

BERNARDO, L.D. Métodos e técnicas de tratamento de água. Rio de Janeiro: ABES, 1993. 496p.

BERTAZZOLI,R.;PELEGRINE,R. Descoloração e degradação de poluentes orgânicos em solução aquosa através do processo fotoeletroquímico. Química Nova v.25,p.477-482,2002

BETTIOL, W.; CAMARGO, O. A., ed. Impacto ambiental do uso agrícola do lodo de esgoto. Jaguariúna: Embrapa Meio Ambiente, 2000. 312p.

BOLTZ, D. F., ed 1958. Colorimetric Determination of Nonmetals. Interscience Publishers, new York, N.Y.

BUCHAN, R.; YARAR, B., Recovering Plastics for Recycling by Mineral Processing Techniques. JOM, v. 47, n.2, p.52-55,1995.

CAÑIZARES, P.; MARTÍNEZ, F.; JIMENEZ, C.; SÁEZ, C.; RODRIGO, M. A. Coagulation and electrocoagulation of oil-in-water emulsions. J. Hazard. Mater., in press.

CASQUEIRA, R.G.; TOREM, M.L.; KOHLER, H.M., The removal of zinc from liquid streams by electroflotation. Miner. Engin. V.19, p.1388-1392, 2006.

CASQUEIRA,R. G.; TOREM, M. L.; SOUZA, V. M. M.; CUNHA, F. O.; PACHECO, A. C. C., Influência das cargas Minerais na Remoção de Tinta por Flotação. In: $57^{\circ}$ Congresso Anual da ABM, 2002, São Paulo. Anais do 57ํㅡㄹ Congresso Anual da ABM. São Paulo: Tec Art Editora, v. único. P2326-2335,2002.

CASTRO, A.M., CASTILHOS, Z. C., LIMA, C. A., Avaliação de Riscos à Saúde Humana por Exposição a HPAs Encontrados em Poeiras das Ruas de Niterói. XIII Jornada de Iniciação Científica - CETEM, 
CHEN, X.; CHEN, C.; YUE, P. L. Separation of Pollutants from Restaurants by Electrocoagulation. Sep. and Purif. Technol., v19, p.65-76, 2000.

CLESCERI,L.S.;GREENBERG,AE.;EATON,AD.Standard Methods for the Water and Wastewater. $20^{\text {th }}$ ed. Washington, American Public Health Association, 1998. $1204 p$.

CETESB (Companhia de Tecnologia de Saneamento Ambiental). Disponível em: http://www.cetesb.sp.gov.br/Agua/rios/variaveis.asp . Acesso em 30 mai.2006

CRESPILHO,F.N.;REZENDE,M.O.O. Eletroflotação: Princípios e Aplicações 1ed. São Carlos, Rima, 2004.

CRESPILHO, Frank Nelson. Eletroflotação Aplicada no Tratamento de Efluente da Indústria de Processamento de Coco. 2004 19-21p. dissertação (Mestrado)Instituto de Química de São Carlos, Universidade de São Paulo, São Carlos, 2004.

CRESPILHO,F.N.;REZENDE,M.O.O. Sistema e processo para tratamento de águas residuárias, $n^{0}$ 0.502.968-6 - Revista de Propriedade Industrial - RPI $n^{0} 1810$, pág. 139, item 2.1 (Notificação de depósito de pedido de patente), de Frank Nelson Crespilho, e Maria Olímpia de Oliveira Rezende (2005).

DECRETO $N^{\circ}$ 8.468, de 8 de Setembro de 1976. Disponiel em:

<www.cetesb.sp.gov.br/institucional/dec8468.pdf>. Acesso em: 12 nov. 2006.

DRODZDA, T., J.; WICK, C. 1983. Tool and manufacturing Engineers Handbook - Machining. 4th ed. Dearborn: Society of Manufacturing.Engineers, Michigan, USA, $302 \mathrm{pp}$.

DROSTE, R.L. Theory and practice of water and wastewater treatment. USA, John Wiley \& Sons, Inc., 1997.

DUYVESTEYN,S., Removal of trace Metals Ions from Dilute Solutions by Ion Flotation: Cadmium-Dodecyl Sulfate and Copper-DodecylSulfate System. Master Thesis, University of California at Berkeley, USA,49p., 1993.

ECKENFELDER,J.W.W. Industrial Water polluition Control.2.ed.New York, Mcgraw-Hill, 1989.400p.

ENVIROMENTAL PROTECTION AGENCY. Acid digestion of sediments, sludges and soils: method 3050B. Washington: EPA, 1996. 12p.

. Acid digestion of waters for total recoverable or dissolved metals for analysis by FLA A OR ICP spectroscopy. Method 3005A, 1992, 5p.

ENVIRONMENTAL PROTECTION AGENCY - EPA. Disponível em: <http://www.epa.gov.br>. Acesso em: 01 setembro 2006. 
ENVIRONMENTAL PROTECTION AGENCY. 1984. Definition and procedure for the determination of method detection limits. Appendix B to 40 CFR 136 rev.1.11 emended June 30, 1986. 49. CFR 43430.

ENVIRONMENTAL PROTECTION AGENCY 1979. Methods for chemical Analysis of water and wastes. Method 353.3.v.S. Environmental protection Agency, Washington, D. C.

ESSADKI, A.H., BENNAJAH, M.; GOURICH, B.; VIAL, CH.; AZZI, M.; DELMAS, H., Electrocoagulation/electroflotation in an external-loop airlift reactor-Application to the decolorization of textile dye wastewater: A case study. Chem. Engin. and Proc. in press.

FILHO, P.J.S., CARAMÃO, E. B., ZANIN, K. D. , GARCIA, R. C. , VALCÁRCEL, M. , RIOS, A., Pré-Concentração de Nitrosaminas a Partir de Amostras Aquosas por Extração em Fase Sólida e Cromatografia Capila, Decreto $n^{\circ} 8.468$, de 8 de Setembro de 1976, que dispõe sobre a Prevenção e o Controle da Poluição do Meio Ambiente.

GANI, A. JR. Eletrocoagulação no Tratamento de Efluentes, Tratamento de Superfícies Ano XXIII no 111: ABTS, 2002, p 20-24.

GRIEVES,R.B.,Foam Fractionation and Ion Flotation of Simple and Complex Anions with Cationic Surfactant.Israel Journal of Chemistry,v.30,p.263-270,1990.

HOLT,P.K.;BARTON,G.W.;WARK M.;MITCHELL C.A.;Quantitative Comparison Between Chemical Dosing and Electroagulation. Colloids Surf.,v.211,p.233$248,2002$.

HOSNY, A.Y. Separating oil from oil-water emulsions by eletroflotation technique. Separation Technology. New York, v.6, 1,p. 9-17, Feb. 1996.

HUNTER, R.J. Introduction to Modern Colloid Science. New York, Oxford University Press Inc., 1993. 338p

IAGREGA. M.D.;PHILLIP,I.B.;JEFFREEY,C.E. Hazardous Waste Management. 2.ed. New York, Mcgraw-Hill,2001.1202p.

IGNÁCIO, A.E. Caracterização da legislação ambiental brasileira voltada para a utilização de fluidos de corte na indústria metal-mecânica. Disponível em: http://www.eps.ufsc.br/disserta98/ignacio/index.html/>. Acesso em 30 dez.2007.

IGNÁCIO,A.E. Caracterização da legislação ambiental brasileira voltada para a utilização de fluidos de corte na indústria metal-mecânica. 
Dissertação(Mestrado) - programa de pós- graduação em engenharia de produção, Universidade Federal de santa Catarina,Florianópolis,1998.

JONG,T;PARRY,D.L. Removal of Sulfate and Heavy Metals by Sulfate Reducing Bacteria in Short-Term Bench Scale Upflow Anaerobic packed Bed Reactor Runs. Water Res.v.37,p.3379-3389,2003.

JOHN, V. M. Panorama sobre a reciclagem na construção civil. Revista Limpeza Pública, v. 53, p. 8-11, 1999.

JENKINS, D. \& HERMANOWICZ, S.W. "Principles of chemical phosphate removal", in Phosphorus and nitrogen removal from municipal wastewater, 2nd ed., R.I. Sedlak, ed., Chelsea, MI, Lewis Publishers, 1991.

KHELIFA, A.; MOULAY, S.; NACEUR, A. W., Treatment of metal finishing effluents by the electroflotation technique. Desalination, v.181, p.27-33, 2005.

KITSON, RE. \& m. g. MELLON. 1944. Colorimetric determination of phosphorus as molybdovanado phosphoric acid. Ind. Eng. Dhem., Anal ed 16: 379.

Khoufi, S.; Feki, F.; Sayadi, S., Detoxification of olive mill wastewater by electrocoagulation and sedimentation processes, J. Hazard. Mater., v. 142, p.5867, 2007.

LABCONCQ. To Kjeldahl Nitrogen determination methods and apparatus. ExpotechUSA, Houston, texas, USA. Disponível em: http://www.expotechusa.com/catalogs/labconco/pdf/KJELDAHLguide. PDF>. Acesso em: 06 setembro 2006.

LEITE, F. Validação em Análise Química.1ª ed . São Paulo, Átomo, 1996 MANSOUR, L. B.; KSENTINI, I. ; ELLEUCH, B., Treatment of wastewaters of paper industry by coagulation-electroflotation. Desalination, v.208, p. 34-41, 2007.

MAIA, J. C. C.; BEZERRA, J. F. M. Aplicação de flotação por ar dissolvido no tratamento de despejos liquidos industriais. In: Congresso Brasileiro de Engenharia Sanitária e Ambiental, 11, Fortaleza,1981. Anais. Fortaleza, ABES, 1981.

MELQUIADES, R.A., LOBO, I. , GUEDES, C. L. B., PINTO, J. P., Análise de benzeno, tolueno, etilbenzeno e xilenos em solos por headspace e cromatografia gasosa/detector de ionização de chama. Semina: Ciencias Exatas e Tecnológicas. 27(2): p. 113-120, 2006

METCALF, E. Wastewater Engineering: Treatment Disposal Reuse, 3.ed.New York, Mcgraw-Hill,1991.1334p 
MOLLAH, M. Y. A.; SCHENNACH, R.; PARGA, J.; COCKE, D. I. Electrocoagulation (EC) - Science and Applications. J. Hazard. Mater., v.84, p.29-41, 2001.

MONICl, R. D., 1999, Relatório de estágio Supervisionado, CETESB -

Companhia de Tecnologia de Saneamento Ambiental, novembro de 1999, p-33, Bauru-SP.

MOORE, W.A.; KRONER, E.C.; RUCHHOFT , C.C. Dichromate reflux method for determination of oxygen consumed. Anal. Chem. 21: 953. 1949.

MOTTA, F. e A. R. Machado. FLUIDOS DE CORTE: TIPOS, FUNÇÕES, SELEÇÃO, MÉTODOS DE APLICAÇÃO E MANUTENÇÃO. Revista Máquinas e Metais. Editora Aranda Ltda. São Paulo-SP. Setembro, 1995. p. 44-56.

Mouedhen, G.; Feki, M.; Wery, M. P.; Ayedi, H.F. Behavior of aluminum electrodes in electrocoagulation process. J. Hazard. Mater., in press.

NERBITT.C.C. and DAVIS, T.E., Removal of Heavy Metals from metallurgical Effluents by the Simultaneous Precipitation and Flotation of Metal Sulfides Using Column Cells. In: Extraction of Metal Sulfides Using Column Cells. In: Extration and Processing for the Treatment and Minimization of Wastes, The Minerals, Metals and materials Society, p.331-342,1994.

NETTO, A.D., DIAS, A. E. X. , MOREIRA, J. C. , ARBILLA, G. , FERREIRA, L. F. V., OLIVEIRA, A. S. , BAREK, J. , Avaliação da Contaminação Humana por Hidrocarbonetos Policíclicos Aromáticos (HPAs) e seus derivados nitrados (NHPAS): uma revisão Metodológica. . Química Nova. 23(6): p. 765-773, 2000

NISHINO, T. Recovery of Phosphoric Acid from Waste Phosphate Sludge by Dissolution Using Íon Exchange Resin. Journal of Japan Society of Waste Management Experts, v. 5, p. 202-208, 1994.

OCCUPATIONAL SAFETY AND HEALTH ADMINISTRATION (OSHA). Metalworking Fluids: Safety and Health Best Pratices Manual. Disponível em :<http://www.osha.gov/SLTC/metalworkingfluids/metalworkingfluids_manual.html>. Acesso em: 16 outubro 2007.

OLIVEIRA, A.P.; TOREM, M.L., A Reciclagem de Papel Impresso, Saneamento Ambiental,n.37.48-52,1995.

OLIVEIRA BRETT, A. M. \& BRETT, C.M;A. Electroquímica, princípios, métodos e aplicações, Coimbra, Portugal,: Editora Almedina, 1996

PINFOLD,T.A., Ion Flotation, In: Lemlich.,R.,Adsorptive Bubble Separation Techniques, Academic press, p.53-73,1972 
QUEIROZ, J. L.L. (2001). Desenvolvimento de um potótipo de software para controle variável ambiental na utilização do fluido de corte. Departemento de Engenharia de produção. Florianópolis, Universidade Federal de santa catarina. Mestrado.

PROFT, G. 1964. Determination of total phosphorus in water and wastewater as molybdovano phosphoric acid. Limnologica 2:407.

RESOLUÇÃO CONAMA N 09/93 (Recolhimento e destinação adequada de óleos lubrificantes). Disponível em : <http://www.mma.gov.br/port/conama/res/res93/res0993.html >. Acesso em 20 de março 2008.

RESOLUÇÃO CONAMA N³13/02 (Inventário Nacional de Resíduos Sólidos Industriais). Disponivel em: <www.mma.gov.br/port/conama/res02/res31302.html >. Acesso em: 12 abril de 2008.

RESOLUÇÃO 357/2005 (Classificação dos corpos de água e diretrizes ambientais para seu enquadramento). Disponível em: < www.mma.gov.br/port/conama/res05/res35705.pdf >. Acesso em: 28 de setembro de 2006.

RICHTER,C.A.; NETTO, J.M.A. Tratamento de Água. Tecnologia Atualizada.São Paulo, Edgard Blucher LTDA,1991.332p.

RUNGE, Peter R. F. e Gilson N. Duarte. LUBRIFICANTES NAS INDÚSTRIAS. Triboconcept Editora Ltda. Carapicuiba-SP.,1990, p. 73-172.

RUNGE, PR.F.D., G.N. Lubrificantes nas Indústrias- Produção, manutenção e controle. Triboconcept- edições Técnicas: 71-171, 1990.

SANTANA, Claudemir Gomes. Remoção de óleos e graxas pelo processo de flotação por era dissolvido em água residuária proveniente de industria de coco. 2003 89f. Dissertação (Mestrado) - Instituto de Química de São Carlos, Universidade de São Paulo, São Carlos, 2003.

Standard Methods for the Examination of Water and Wastewater (20th edition). 5210B, NBR.10741. Rio de Janeiro: ABNT, 1989. 5p.

STUMM, W.; MORGAN, J.J. Aquatic Chemistry.1.ed.New York, Wiley,1981.780p.

SWIFT, G. Requirements for Biodegradable Water-Souble Polymer. Polym. Degrad. Stab.v.59,p19-24,1998. 
THOMPSON, M. AnalyticaL Performance of Inductively Coupled Plasma Atomic Emission Spectrometry. In: MOTASER, A .; GOLICHTLY, D.W. Inductively Coupled

Plasma in Analytical Spectrometry. New York: VHC publishers INC, 1987, p.163-199.

VON SPERLING, M. Introdução a Qualidade das Águas e ao Tratamento de Esgotos. V.1, 2ª̣ed., Departamento de Engenharia Sanitária e Ambiental - UFMG, Belo Horizonte, 2004.

WALKOWIAK,W., Mechanism of Selective Ion Flotation. In: Innovations in Flotation Technology, Kewwer academic Publishers, Netherlands,p.455-473,1992.

YASUHARA, T.; NOKIHARA, K. High-throughput analysis of total nitrogen content that replaces the classic Kjeldahl method. Journal of agricultural and food chemistry, v. 49, p. 4581-4583, 2001.

ZAMBETTA, P.M.A. Espécies químicas inorgânicas no sedimentoe nos sólidos em suspensão do Rio Corumbataí, SP. 2006 . 73p. Dissertação (Mestrado) Escola Superior de Agricultura "Luiz de Queiroz", Universidade de São paulo, Piracicaba, 2006

ZOUBOULIS,A.I., Íon Flotation in Enviromental Technology. Chemosphere, v.16, n2/3,p623-631,1987.

ZOUBOLIS, A.I., MATIS, K.A. Removal of cadmium from dilute solutin by flotation.Water Science Technology. London, v.31,n. 